\title{
QUANTIFYING THE IMPACT OF TRUCK ONLY LANES ON VEHICULAR EMISSIONS ON A LIMITED-ACCESS HIGHWAY
}

\author{
A Thesis \\ presented to \\ the Faculty of California Polytechnic State University, \\ San Luis Obispo
}

\author{
In Partial Fulfillment \\ of the Requirements for the Degree \\ Master of Science in Civil and Environmental Engineering \\ by \\ Edward Chee Tang \\ June 2017
}


(C) 2017

Edward Chee Tang

\section{ALL RIGHTS RESERVED}


TITLE: Quantifying the Impact of Truck Only Lanes on

Vehicular Emissions on a Limited-Access Highway

AUTHOR: Edward Chee Tang

DATE SUBMITTED: June 2017

COMMITTEE CHAIR: Anurag Pande, Ph.D.

Associate Professor

Department of Civil and Environmental Engineering

California Polytechnic State University, San Luis

Obispo

COMMITTEE MEMBER: Sam Vigil, Ph.D., P.E., LEED AP

Professor Emeritus

Department of Civil and Environmental Engineering

California Polytechnic State University, San Luis

Obispo

COMMITTEE MEMBER: Kimberley Mastako, Ph.D.

Lecturer

Department of Civil and Environmental Engineering California Polytechnic State University, San Luis

Obispo

COMMITTEE MEMBER: Hatem Abou-Senna, Ph.D., P.E.

Assistant Professor

Department of Civil, Environmental, and

Construction Engineering

University of Central Florida

COMMITTEE MEMBER: Robert Bertini, Ph.D., P.E.

Director, Center for Urban Transportation Research

University of South Florida 


\section{ABSTRACT \\ Quantifying the Impact of Truck Only Lanes on Vehicular Emissions on a Limited-Access Highway \\ Edward Chee Tang}

This thesis seeks to estimate $\mathrm{CO}_{2}$ emissions on a portion of the U.S. 101 highway in San Luis Obispo County before and after construction of a truck only lane on the Cuesta Grade. Towards that aim, the microsimulation software, VISSIM, was used in conjunction with the Environmental Protection Agency's emissions model, MOVES. The microsimulation model was calibrated and validated against historical and present traffic volumes obtained from Caltrans with good results using several validation measures. It was found that $\mathrm{CO}_{2}$ emissions did decrease between 1998 and 2012 (pre and post lane addition), but this effect was shown to be different for the northbound (uphill) and southbound (downhill) directions. It was shown that the truck lane in the northbound (uphill) direction had a $9.5 \%$ decrease in volume with $10.7 \%$ decrease in emissions, and the southbound (downhill) direction had a $20.3 \%$ increase in volume but $7.4 \%$ decrease in emissions. For the northbound (uphill) direction, emissions seemed to correlate more closely with volumes, while the southbound (downhill) direction was less sensitive to these changes.

Keywords: Emissions, Limited-Access Highway, VISSIM, MOVES, Truck Only Lane 


\section{ACKNOWLEDGMENTS}

This thesis is dedicated to all the family, friends, colleagues, and mentors that guided and supported me throughout this work.

First and foremost, I would like to thank the committee for their patience and direction. I'd like to thank Dr. Pande for his unrelenting support as I explored this research. I was always confident in his expertise and knowledge, and having such a reliable advisor made this work possible. His mild-mannered demeanor and open mind have been invaluable personal traits that have made working with him an incredible pleasure at Cal Poly. l'd like to thank Dr. Bertini for convincing me to take on the challenge of a thesis which has given me the confidence to face seemingly insurmountable obstacles. His support and genuine care for student success has always been appreciated. l'd like to thank Dr. Vigil for providing his invaluable insight into the project with regards to the emissions analysis. I'd like to thank Dr. Mastako for taking the time to offer her wisdom and support in completing this work. l'd like to thank Dr. Abou-Senna for his immense contribution to the project by providing the emissions data and offering guidance on this research.

l'd also like to thank my colleagues at the San Francisco Municipal

Transportation Agency for their incredible support. l'd like to thank my supervisor, Robert Lim, whom I consider to be a mentor that pushed me every week to finish this thesis. His support gave me the motivation to complete this work, and I continue to grow professionally on a daily basis due to his guidance. l'd like to thank other members of my team that have helped me grow in countless other ways. These people include Alvin Lam, Jean Long, and Ramon Zamora.

l'd like to thank my immediate family and friends for their never-ending support and wisdom. These people include my parents, Augustine and Ming Tang, my brother, Steven Tang, and lifelong friend, Daniel Kim.

Finally, l'd like to thank my cat, Ninja, for always being there in good times and bad. 
LIST OF TABLES ................................................................................ vii

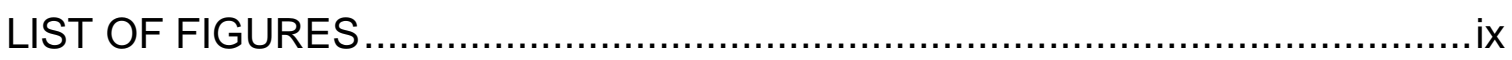
CHAPTER

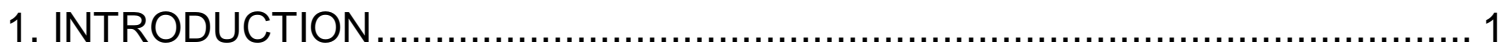

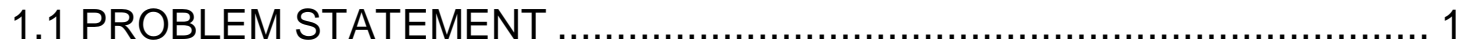

1.1.1 Greenhouse Gas Emissions Trends in the United States ................... 1

1.1.2 Types of Emissions .................................................................. 5

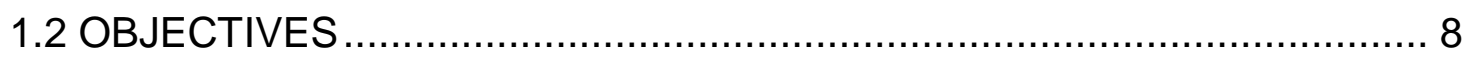

2. BACKGROUND AND LITERATURE REVIEW ….................................... 9

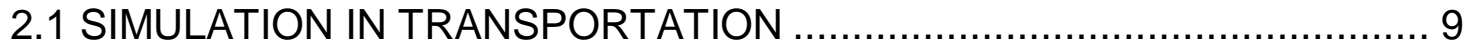

2.1.1 Macrosimulation vs. Microsimulation ................................................ 9

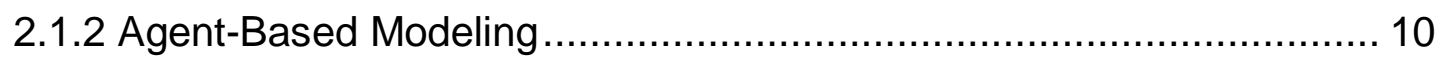

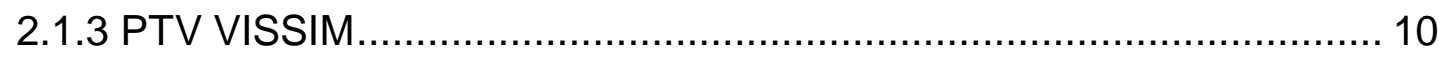

2.1.3.1 VISSIM Components and Applications ..................................... 11

2.1.3.2 Car Following Model ................................................................ 11

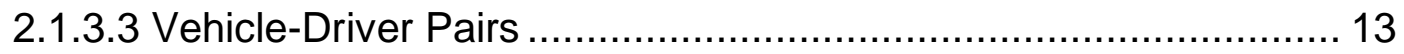

2.1.4 EPA's MOtor Vehicle Emission Simulator (MOVES) ......................... 13

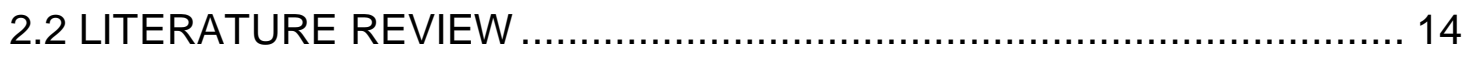

2.2.1 Estimating Aggregate Vehicle Emissions Using Simulation Models ... 14

2.2.2 Estimating Individual Vehicle Emissions Using Simulation Models..... 17

2.2.3 How Geography and Roadway Characteristics Impact Vehicle Emissions

2.2.4 Modeling Traffic Emissions Based on Vehicle Type and Driver Behavior

2.2.5 Validation of Microscopic Traffic Simulation Models with Real

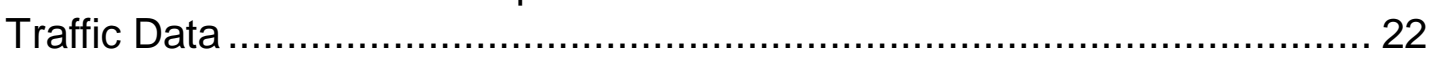

2.2.6 Analysis of MOVES and CMEM for Evaluating the Emissions Impacts of an Intersection Control Change .............................................. 23

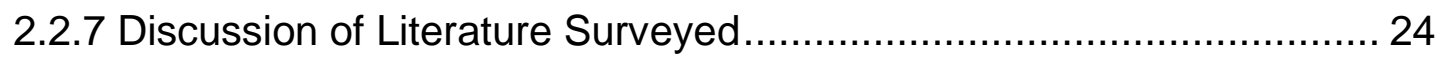

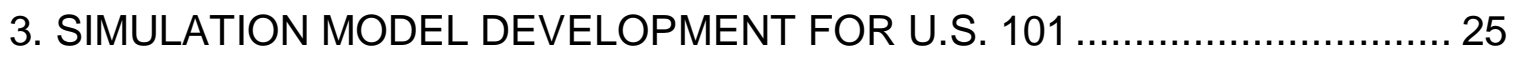




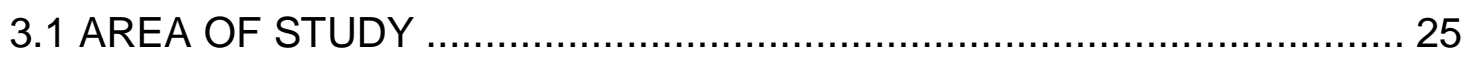

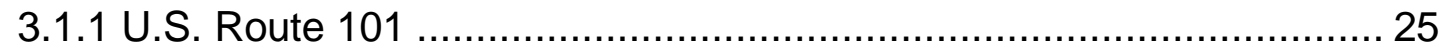

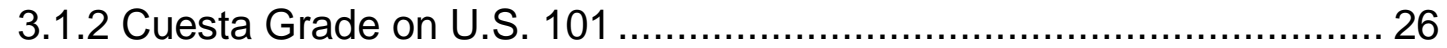

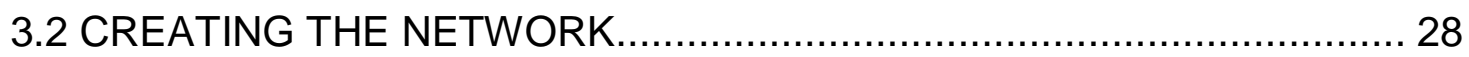

3.2.1 Before-and-After Comparison ................................................... 28

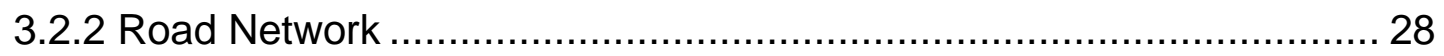

3.2.3 Vehicle Data and Composition ..................................................... 29

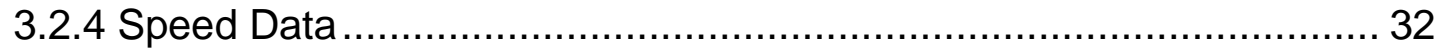

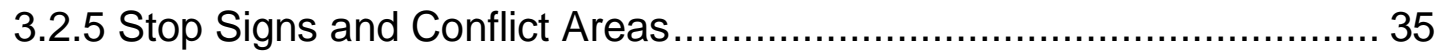

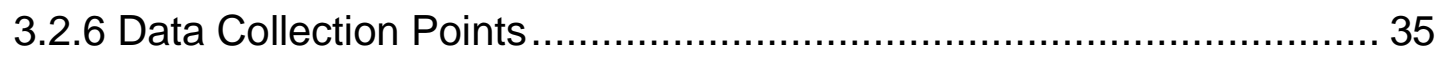

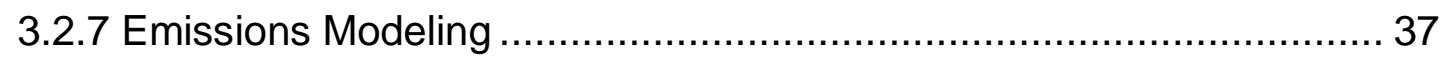

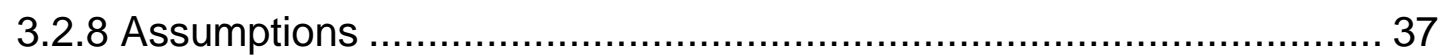

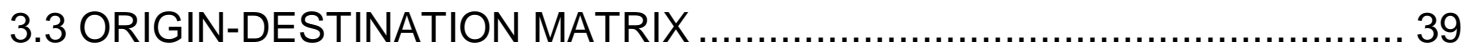

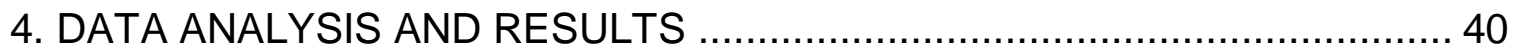

4.1 CALIBRATION AND VALIDATION ...................................................... 40

4.1.1 Calibration Parameters ................................................................... 40

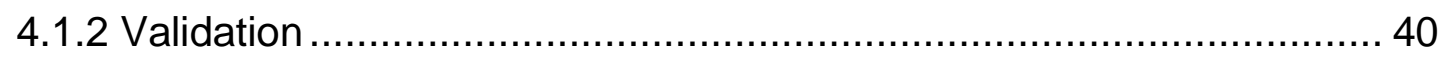

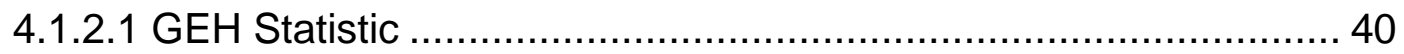

4.1.2.2 Root Mean Squared Error ..................................................... 41

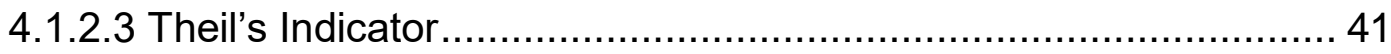

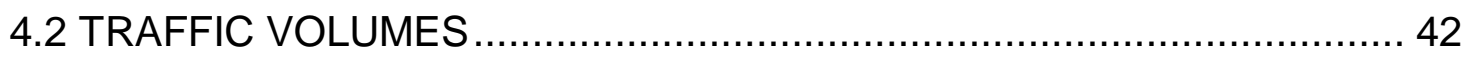

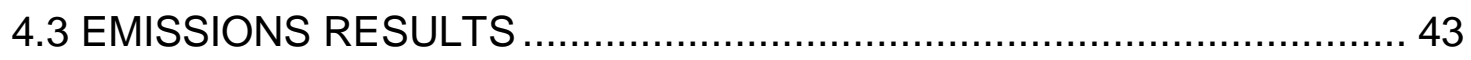

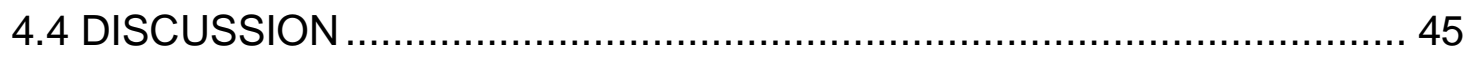

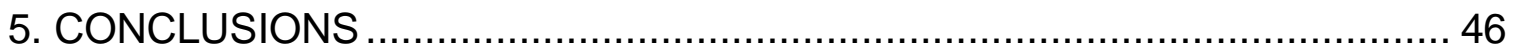

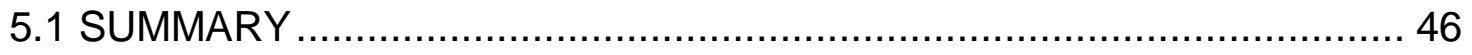

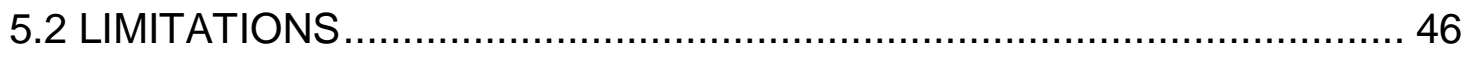

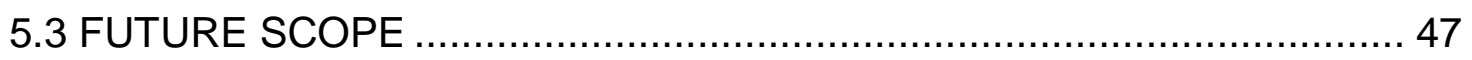

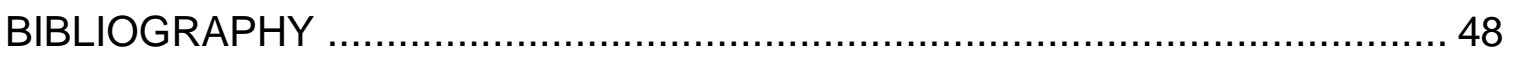

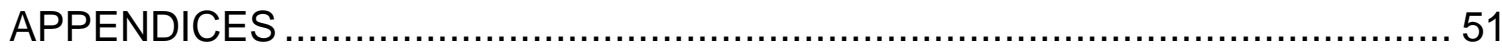

APPENDIX A: LIST OF VISSIM LINKS AND GRADIENTS (NETWORK 1) .......51 APPENDIX B: ORIGIN-DESTINATION MATRICES ...................................... 64

APPENDIX C: VISSIM DATA COLLECTION OUTPUT .................................... 67 


\section{LIST OF TABLES}

Page

Table 1. List of GHG and their respective GWP and Lifetime ......................... 6

Table 2. Northbound Volume Inputs (Vehicles Per Hour) ................................ 30

Table 3. Southbound Volume Inputs (Vehicles Per Hour) ............................... 30

Table 4. Validation Measures and Thresholds ............................................. 42

Table 5. Network 1 (4-lane) Traffic Volume Results......................................... 42

Table 6. Network 2 (6-lane) Traffic Volume Results......................................... 43

Table 7. Inputs for MOVES Emissions Modeling …….................................. 44

Table 8. MOVES Emissions Estimates ..................................................... 44 


\section{LIST OF FIGURES}

Page

Figure 1. $\mathrm{CO}_{2}$ emissions trends from the transportation sector. .................. 3

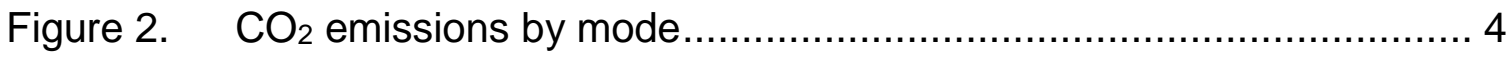

Figure 3. Wiedemann car following model ...................................... 12

Figure 4. Cuesta grade aerial view.................................................. 26

Figure 5. Speed distribution for cars and light trucks.......................... 32

Figure 6. $\quad$ Speed distribution for heavy goods vehicles ............................ 33

Figure 7. Speed distribution for reduced speed area for HGV .................... 34

Figure 8. Locations of data collection measurement points ..................... 36 


\section{INTRODUCTION}

Greenhouse gas (GHG) emissions and other pollutants have long impacted global climate, public health, and the economy. Hundreds of studies already explore these effects, but quantifying these emissions is a critical step towards addressing them. In the transportation sector, emissions vary based on the type of vehicle, and simulation is a tool that can help quantify these sources. The transportation sector is a major source of carbon dioxide $\left(\mathrm{CO}_{2}\right)$ emissions, being second only to the electric utility sector (EPA, 2014). A few studies have used simulation to estimate emissions (Abou-Senna et al., 2013; Ahn et al., 1998; Chamberlin et al., 2011). Microscopic traffic simulation is a relatively low-cost and effective tool commonly used to create models to evaluate traffic systems under a variety of circumstances. These models are capable of realistically simulating a built and/or planned environment and generate outputs such as travel time, level of service, queuing, and other performance measures. Over various iterations of calibration, models can be improved over time to generate more accurate information. These data are useful to guide decision-makers, planners, and engineers when designing infrastructure in any type of urban or rural environment.

\subsection{PROBLEM STATEMENT}

\subsubsection{Greenhouse Gas Emissions Trends in the United States}

The Intergovernmental Panel on Climate Change's (IPCC) latest report shows that global average temperature continues to increase and is at the highest point 
in recorded history (2014). With increasing mobilization of people and goods over time, the number of vehicle miles traveled (VMT) in the United States has increased. Despite an increasingly efficient vehicle fleet (both in terms of fuel consumption and emissions) and policies aimed at curbing emissions, GHG emissions totaled 6,870 million metric tons of carbon dioxide equivalents, and transportation accounted for $26 \%$ of total GHG emissions in the United States. (EPA, 2014). Approximately $72 \%$ of total transportation emissions come from limited-access highways and freeways, with more than half of emissions generated from light cars and trucks (Green \& Schafer, 2003).

Figure 1 represents transportation's impact on GHG emissions from 1990 2014. A slight decline in 2007 shows the effects of the economic recession (higher unemployment resulting in fewer VMT). The trend has remained mostly flat with the subsequent economic recovery, but $\mathrm{CO}_{2}$ levels are still $16.3 \%$ higher than 1990 levels (EPA, 2014). In 2013, the EPA found that freight trucks were responsible for $22.8 \%$ of $\mathrm{CO}_{2}$ emissions from the transportation sector, and cars contributed $42.7 \%$ (Figure 2). Given transportation's influence on GHG emissions and climate change, there is continued concern among the federal, state, and local levels to implement policies to reduce transportation emissions. The primary focus of any reductions goals should concentrate on highways and freeways. 
U.S. Greenhouse Gas Emissions from the Transportation Sector, 1990-2014

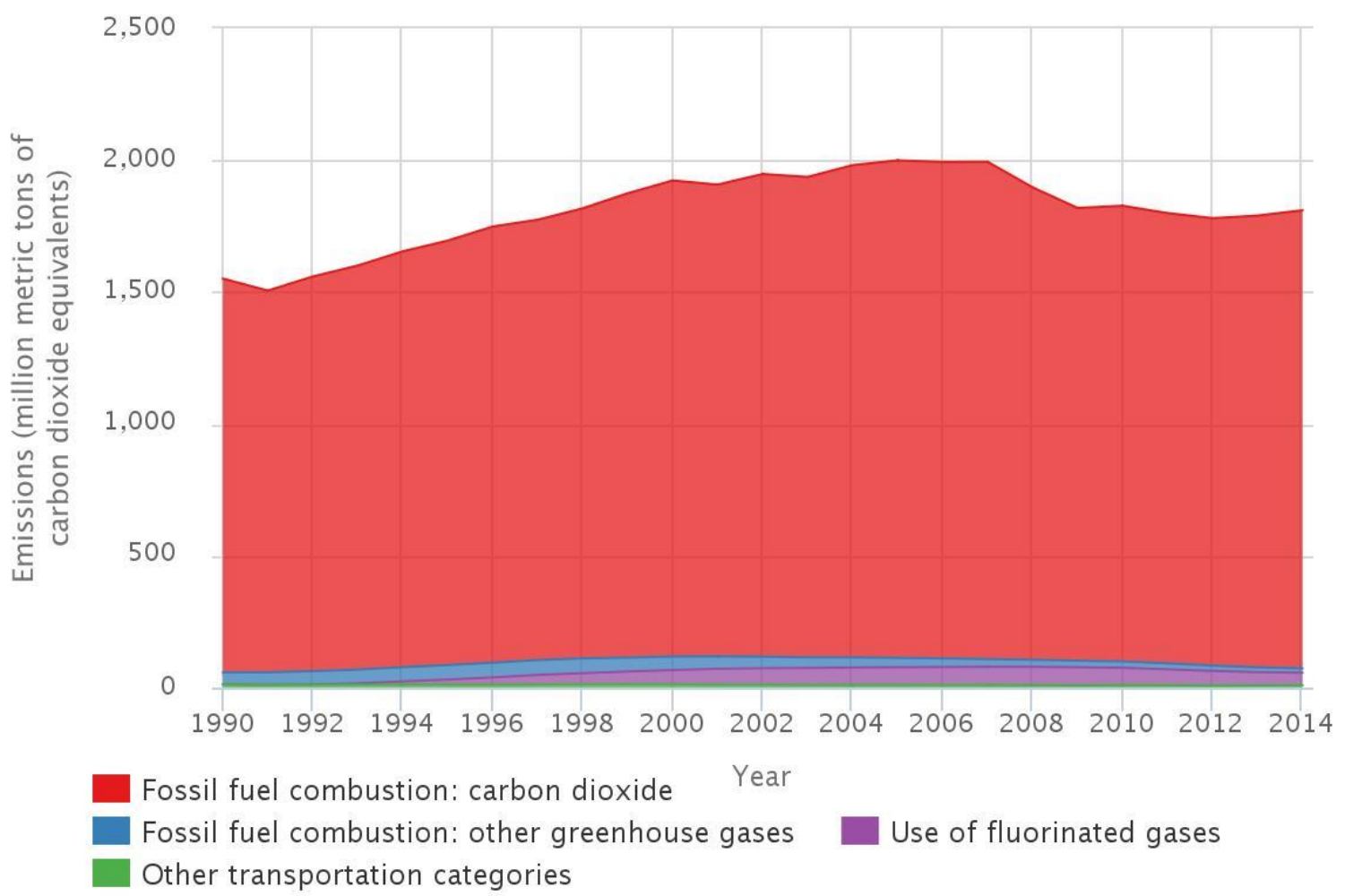

Source: U.S. EPA's Inventory of U.S. Greenhouse Gas Emissions and Sinks: 1990-2014. http://www.epa.gov/climatechange/ghgemissions/usinventoryreport.html

Figure 1. $\mathrm{CO}_{2}$ emissions trends from the transportation sector. 


\section{U.S. Carbon Dioxide Emissions by Mode, 2013}

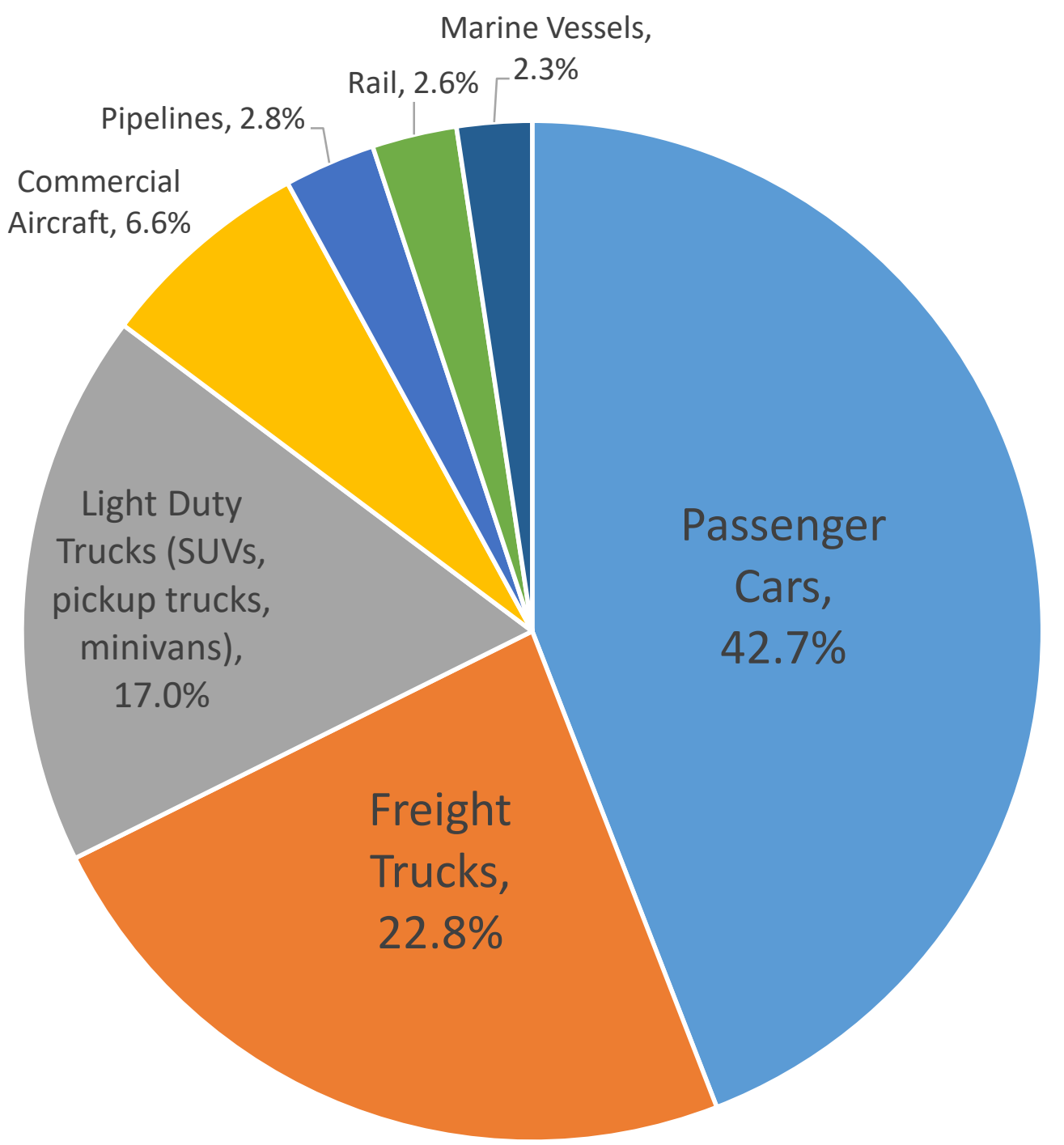

Source: U.S. EPA's Inventory of U.S. Greenhouse Gas Emissions and Sinks: 1990-2013

Figure 2. $\mathrm{CO}_{2}$ emissions by mode 


\subsubsection{Types of Emissions}

Emissions are classified as anthropogenic sources of air pollution and come from many sources. These sources include transportation, energy production, agriculture, manufacturing, and other industrial processes. The EPA has set National Ambient Air Quality Standards (NAAQS) that list six "criteria" air pollutants considered harmful to human health (carbon monoxide, lead, nitrogen dioxide, ozone, particulate matter, and sulfur dioxide).

Emissions not considered "criteria" air pollutants are considered GHG. The EPA lists four main GHG (carbon dioxide, methane, nitrous oxide, and fluorinated gases). The impact of each gas on global warming is quantified with a global warming potential (GWP), and these are listed in Table 1. The GWP represents how much energy the emissions of one ton of gas will absorb relative to the reference gas over a given time scale. The reference gas is carbon dioxide and has a GWP of 1. 
Table 1. List of GHG and their respective GWP and Lifetime Greenhouse Gas $\quad$ GWP Lifetime in Atmosphere (years)

Carbon Dioxide $\left(\mathrm{CO}_{2}\right) \quad 1$ (reference gas) $>1000$

Methane $\left(\mathrm{CH}_{4}\right) \quad 28-36$ over $100 \quad \sim 10$

years

Nitrous Oxide $\left(\mathrm{N}_{2} \mathrm{O}\right) \quad 265-298$ over $100>100$

years

Fluorinated Gases ${ }^{1}$

$\begin{array}{lll}\text { HFCs } & 12-14,800 & 1-270 \\ \text { PFCs } & 7,390-12,200 & 2,600-50,000 \\ \mathrm{NF}_{3} & 17,200 & 740 \\ \mathrm{SF}_{6} & 22,800 & 3,200\end{array}$

${ }^{1}$ Fluorinated gases include hydrofluorocarbons, perfluorocarbons, nitrogen trifluoride, and sulfur hexafluorides 
Research has been done to more precisely determine the extent of vehicular emissions. Maness et al. obtained accurate emissions data for a highway by conducting in-situ measurements with a test vehicle equipped with a GPS probe and $\mathrm{CO}_{2}$ sensors (2015). While some research has explored the effects of grades on GHG emissions, this required a similar approach necessitating a properly equipped test vehicle (Cicero-Fernândez et al., 2011; Boriboonson \& Barth, 2009). Test vehicles are accurate but can be costly and time-consuming. Estimating GHG emissions on grades can be accomplished more efficiently with microscopic traffic simulation and integrating the results with an emissions model. The latest US EPA emissions model MOVES (Motor Vehicle Emissions Simulator) creates this opportunity. MOVES is a comprehensive GHG emissions model that can estimate $\mathrm{CO}_{2}$ emissions of nearly any mobile source. Forecasting emissions is also possible with simulation as the model can be calibrated to nearly any scenario.

A plethora of research continues to support evidence that anthropogenic activity contributes to increasing levels of emissions, resulting in localized health problems and global climate change. In the United States, this has been mitigated to some extent by the Clean Air Act passed in 1973. More work is needed to address the rise of GHG emissions, which do not have direct impacts on human health, but have far-reaching impacts on the global scale. Using simulation to estimate GHG emissions is a useful tool for policy-makers to recognize trends in their region and develop goals to reduce emissions. 


\subsection{OBJECTIVES}

U.S. 101 is a corridor that passes through San Luis Obispo but may handle traffic more regional travel from goods and people than local travel. With a valid simulation model that accurately reflects factors such as highway capacity, grades, meteorological conditions, and vehicle volumes and speeds, it is possible to estimate GHG emissions. The objectives of this study are:

- To create a properly calibrated and validated traffic simulation model in VISSIM that reflects PM peak traffic conditions on the Cuesta Grade of U.S. 101 (refer to Section 3 for more details of the study area), including volumes, speeds, and vehicle composition. VISSIM is chosen for its high level of detail and functionality.

- To compute detailed surface $\mathrm{CO}_{2}$ emissions generated by vehicles during this time period using MOVES. Data gathered from VISSIM will be used as inputs for MOVES.

- To compare surface emissions before-and-after the construction of a truck only lane, to determine any impacts, if any.

- To provide the framework for validating the simulation results through a mobile instrument to perform in-situ measurements of $\mathrm{CO}_{2}$ emissions on the Cuesta Grade. Data from in-situ measurements can be used for further calibration of the future simulation-based emissions model. 


\section{BACKGROUND AND LITERATURE REVIEW}

\subsection{SIMULATION IN TRANSPORTATION}

\subsubsection{Macrosimulation vs. Microsimulation}

Simulation can play a significant role in studying and analyzing transportation networks. Whereas collecting real-world data can be expensive and cumbersome, simulation is a relatively cheap, efficient tool that can create reasonably accurate models of traffic congestion, growth, emissions, and changes in infrastructure (signalization, roadway geometry, etc.). Simulation does require data collection for the calibration stage, but this data only needs to be collected once. Macrosimulation and microsimulation are the two approaches that may be adopted in studying the system.

Macrosimulation treats vehicles as an aggregate flow using continuum equations. This approach requires fewer inputs and less effort, but the outputs result in lower levels of detail.

Microsimulation is much more complex and involves modeling individual driver behavior through models for car-following theory, vehicle performance, and lane changing. Microsimulation requires more effort to produce a model but can generate outputs with more information and a higher level of detail.

Microsimulation is preferred for emissions modeling because of the varying characteristics that affect output of GHG. For example, different classes of vehicles will have different levels of fuel consumption and emissions rates. 


\subsubsection{Agent-Based Modeling}

Microsimulation lends itself to agent-based modeling in which agents (vehicles) act as autonomous entities that interact with other agents. Jain et al. (2011) find that agent-based modeling is important when simulating real-world behaviors, when agents adapt and change behavior, and when there are dynamic relationships with other agents. Transportation often reflects many of these characteristics in which each vehicle's behavior is influenced by its own actions and the actions of other vehicles.

\subsubsection{PTV VISSIM}

VISSIM was selected for creation of the model due to its ability to conduct microscopic simulations with agent-based modeling. VISSIM was developed in 1992 by PTV Planung Transport Verkehr AG in Karlsruhe, Germany and today is a global market leader in traffic simulation software. VISSIM is one of the most fully featured simulation software packages available. It is capable of accurately modeling emissions, lane changing/merging, car-following, active traffic management, intelligent transportation systems, multiple simulations, and multimodal scenarios. Its outputs can be used to determine various performance measures (e.g. travel times, delay) which can be used as inputs for other programs. The latest available edition of VISSIM, version 8.0 is used for this study. 


\subsubsection{VISSIM Components and Applications}

VISSIM consists of three main components - traffic simulation, signal modeling, and pedestrian simulation. The traffic simulation component relies on an agentbased microsimulation approach including car-following and lane changing models. Signal modeling incorporates control logic units capable of querying detectors in time steps of $1 / 10$ of a second. Pedestrian simulation uses the Social Force Model described by Helbing and Molnár (1995). In this case, modeling of pedestrians is influenced by their own speed, their desire to maintain spacing between themselves and other objects, and their attraction to other pedestrians or other objects. The study of the Cuesta Grade on U.S. 101 is limited to the traffic simulation component as there are no signals or pedestrians present on this limited-access highway.

\subsubsection{Car Following Model}

VISSIM uses the Wiedemann psycho-physical perception model (1974). In this model, the driver of a faster moving vehicle begins to decelerate upon approaching a slower moving vehicle. As a leading vehicle begins to pull away, the driver begins to accelerate again. The moments that these actions occur depend on the driver's perception threshold which is graphically represented by the Wiedemann model in Figure 3. 


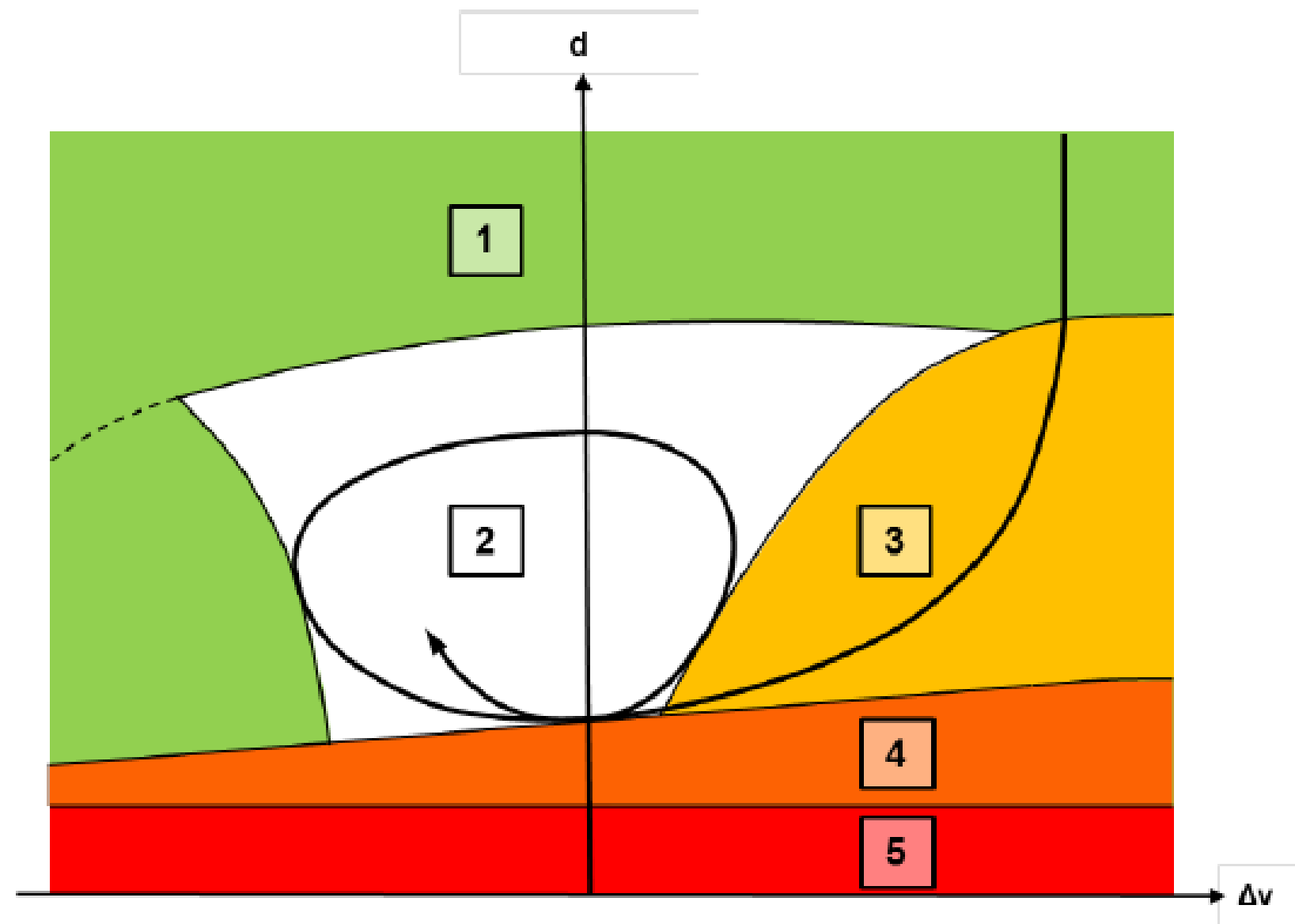

Car following model (according to: Wiedemann 1974)

Figure 3. Wiedemann car following model

Each region represents a "state" in which a vehicle may occupy:

1. Free flow state

2. Following state

3. Approaching state

4. Braking state

5. Collision state 
The $y$-axis represents the gap between vehicles and the $x$-axis shows change in velocity for the driver. Green regions represent acceleration, while yellow, orange, and red regions represent deceleration in varying intensities. A vehicle in the approaching state (region 3) will decrease their velocity as the gap between themselves and the leading vehicle becomes smaller. For example, the free flow state (region 1) shows a large gap between vehicles and a very high increase in velocity. The collision state (region 5) shows a very small gap and therefore a very high decrease in velocity. This attempts to realistically simulate driver behavior, especially on highways and freeways. Panwai and Dia (2005) find that the Wiedemann model used in VISSIM has error comparable to other carfollowing models; however, it still does not completely replicate field measurements.

\subsubsection{Vehicle-Driver Pairs}

In VISSIM, each driver is paired to a vehicle, and the driver's behavior corresponds to the technical aspects of their vehicle. These characteristics include length, maximum speed, and accelerating power. Drivers of heavy trucks will have different behavior than drivers of passenger cars or light-duty trucks. This directly affects any values generated by an emissions model as GHG emissions are heavily influenced by driver behavior such as acceleration.

\subsubsection{EPA's MOtor Vehicle Emission Simulator (MOVES)}

The EPA first developed a series of models in the late 1970s called MOBILE that could estimate hydrocarbons, nitrogen oxides, and carbon monoxide from 
various vehicle classes. MOBILE was able to account for local variations such as temperature, humidity, and fuel quality. The EPA used this model for many years at the local, state, and national level - including contribution to the federal Clean Air Act's state implementation plan. In addition, NONROAD was developed to estimate emissions of off-road mobile sources. Both MOBILE and NONROAD were replaced with a single, comprehensive modeling system known today as MOVES.

The EPA developed and currently maintains MOVES, a comprehensive GHG model that can estimate fuel consumption, $\mathrm{CO}_{2}, \mathrm{~N}_{2} \mathrm{O}, \mathrm{CH}_{4}$, and other vehicular GHG. MOVES can estimate emissions from nearly any mobile source such as passenger cars, light trucks, heavy trucks, marine vessels, locomotives, and aircraft. While MOBILE was able to estimate emissions from three GHG, today's version of MOVES is capable of estimating 1,018 different criteria air pollutants, GHG, and air toxics (EPA, 2015).

\subsection{LITERATURE REVIEW}

The literature reviewed below provides background on traffic simulation, emissions modeling, and calibration/validation of these models.

\subsubsection{Estimating Aggregate Vehicle Emissions Using Simulation Models}

Song et al. (2012) researched the validity of fuel consumption and emissions estimates $\left(\mathrm{CO}, \mathrm{HC}\right.$, and $\left.\mathrm{NO}_{\mathrm{x}}\right)$ generated from a traffic microsimulation model by comparing vehicle-power specific (VSP) distributions created from models and VSP distributions obtained from real-world testing. The researchers collected 
data using VISSIM 5.20 and gathered second-by-second speed and acceleration data to determine VSP using Equation 1:

$$
V S P=v *[1.1 a+9.81 * \operatorname{grade}(\%)+0.132]+0.000302 * v^{3}
$$

where:

$v$. Vehicle speed $(\mathrm{m} / \mathrm{s})$

a: Vehicle acceleration $\left(\mathrm{m} / \mathrm{s}^{2}\right)$

grade (\%): Vehicle vertical rise divided by slope length multiplied by 100 , which can be assumed to be zero where terrain is flat

Song et al. found that simulated VSP distributions were not consistent with those obtained from real-world testing. The microsimulation model overestimated emissions in low-speed conditions and underestimated emissions in high-speed conditions. In an effort to calibrate the VSP generated by VISSIM, they performed a sensitivity analysis by adjusting parameters such as the speed distribution, acceleration, deceleration, etc. Song et al. found that VSP distributions were not affected by the sensitivity analysis, and emissions could not be accurately predicted using simulated VSP distributions.

Abou-Senna et al. (2013) from the University of Central Florida developed a microscopic traffic simulation model on a limited-access highway (Interstate 4) in Orlando, Florida during the PM Peak Hour. Using the EPA's mobile source emissions model, MOVES, they estimated $\mathrm{CO}, \mathrm{NO}_{x}, \mathrm{PM}_{2.5}, \mathrm{PM}_{10}$, and atmospheric $\mathrm{CO}_{2}$ based on a variety of inputs. MOVES is capable of emissions modeling on a great level of detail - traffic volumes, average speeds, 
meteorological conditions, vehicle age, vehicle composition, and fuel type are just some examples of inputs that MOVES can use to generate emissions values. MOVES also generates results on a second-by-second basis. AbouSenna et al. found that emissions rates were highly sensitive to acceleration at low-speeds (i.e. congestion involving frequent braking and acceleration).

Kilbert (2009) created a traffic simulation and emissions model of the California Polytechnic State University, San Luis Obispo campus. VISSIM was used to create a realistic network of the campus, complete with intersection control and comprehensive routing decisions. Kilbert analyzed the AM Peak Hour and used CMEM (an emissions estimator) to generate aggregate emissions values. The goal of the study was to determine the impact of hypothetical transportation demand management policies on emissions. Kilbert concluded that a decrease in demand has a more significant impact on emissions than increase in "green" vehicles. One limitation of the study is that the emissions values are aggregate values and do not target specific locations of high emissions, such as at intersections with higher incidences of stop and go traffic vs. free flowing corridors. By knowing these emissions hot spots, it is possible to determine whether the land use or road features are contributing to increased demand and/or congestion, resulting in higher emissions.

Chamberlin et al. (2012) discuss best practices when conducting project-level analyses using EPA's MOVES software. A project-level analysis with MOVES requires interfacing with a traffic microsimulation model and an air dispersion model. The advantage of microsimulation is that it can capture a higher 
resolution of detail and dynamic behaviors of individual vehicles. Chamberlin et al. discuss the significance of location (specific coordinates) defined in the model for estimating emissions because of inherent variability resulting from network elements such as intersections. A test-bed emissions analysis $\left(\mathrm{PM}_{2.5}\right)$ of an intersection before and after signal optimization was conducted to determine the impacts on emissions. Chamberlin et al. found that using average speed and operating mode distribution (based on VSP) show emissions reductions, and both approaches have similar estimates for fuel consumption. However, the operating mode distribution's results showed greater variability closer to the intersection, more accurately representing variances in acceleration and speed.

\subsubsection{Estimating Individual Vehicle Emissions Using Simulation Models}

Barth et al. (2004) gathered data from the University of California, Riverside mobile emissions research laboratory to develop a model for estimating heavyduty diesel (HDD) vehicle emissions. While emissions models for light-duty vehicles (LDV) have been extensively researched and developed, fewer efforts have been made to develop HDD vehicle emissions models even though HDD vehicles can represent a significant portion of emissions. Barth et al. used a test fleet of 11 vehicles using various procedures to capture real-world emissions data. Test procedures included the California Air Resources Board HDD test, dynamometer testing, real-world driving, and customized modal emission cycles developed by the team. Validation consists of data obtained from the dynamometer testing. Of particular interest is that the model can be adapted to 
test the presence of grades and truck restricted lanes, since the Cuesta Grade involves both of these scenarios.

Increasingly stricter emissions standards for new vehicles have resulted in automakers developing low emitting gasoline powered cars. Barth et al. (2006) from CERT calibrated their CMEM software to include measurements from these low emitting vehicles. Using a similar approach to developing a model for HDD vehicles, a test fleet was utilized on a dynamometer and in real-world driving scenarios. Data from these tests was used to calibrate the model and validated the model results by comparing it to measured tailpipe emissions. Barth et al. found that the model did well to predict emissions, and that existing models poorly predict emissions when compared to empirical data obtained from a dynamometer. However, even on-road measurements differed from the dynamometer tests, highlighting the importance of using real-world data for emissions modeling. They also concluded that extremely low emitting vehicles can have dramatic increases in emissions under high speed conditions. This scenario is not uncommon and should be considered for a comprehensive emissions model.

Nam et al. (2002) equipped a test vehicle with a Portable Emissions Measurements System (PEMS) developed by Ford to measure the impact of driver behavior on vehicle emissions. The test vehicle was driven on an 8.5 mile segment consisting of 17 traffic signals in Oakland County, Southeast Michigan. The researchers drove the vehicle "normally" and "aggressively" to capture different emissions data sets. For the modeled emissions, the researchers used 
VISSIM and CMEM with a complex network consisting of a $4 \times 5$ mile grid. CMEM was calibrated using dynamometer data. Calibrating VISSIM involved creating a virtual vehicle that ran on the same route as the real-world test vehicle. Results showed that while travel times were similar for both normal and aggressive driving styles, fuel consumption and emissions were higher for the aggressive driving style. The VISSIM and CMEM model compared favorably in its generated emissions values, but the authors note that its ability to predict emissions from a low-emitting vehicle was limited.

\subsubsection{How Geography and Roadway Characteristics Impact Vehicle Emissions}

Chu and Meyer (2009) describe a methodology for estimating emissions reductions of truck only toll lanes. Using the U.S. EPA's MOBILE6.2 emissions model (precursor to MOVES), they measured $\mathrm{HC}, \mathrm{CO}, \mathrm{NO}$, and $\mathrm{CO}_{2}$ for gasoline and diesel trucks. The software was limited in that it was unable to use speed as an input for estimating $\mathrm{CO}_{2}$ emissions. The authors used an equation to correlate fuel consumption with $\mathrm{CO}_{2}$ emissions for more accurate results. Chu and Meyer found that voluntary and mandatory use of truck only toll lanes reduced $\mathrm{CO}_{2}$ emissions on freeways by around $62 \%$.

Boriboonsomsin and Barth (2009) researched emissions trends for light-duty vehicles when traveling on a grade. The authors gathered $\mathrm{CO}_{2}$ emissions data by driving a test vehicle, measuring its fuel consumption, and using an empirical formula to determine the emissions generated. The route consisted of a 15 mile segment with average road grade of $4 \%$. Boriboonsomsin and Barth used CMEM to estimate $\mathrm{CO}_{2}$ emissions. The results showed that fuel economy for light-duty 
vehicles on flat roads is $15 \%$ to $20 \%$ better than for the particular segment tested. One limitation acknowledged by the study is that only light-duty vehicles were tested and modeled. Emissions of heavy-duty vehicles, which have a lower power-to-weight ratio, may be more impacted by the presence of grades. Conversely, it is unclear what the effects on hybrid vehicles are.

Papson et al. (2012) used MOVES to predict nitrogen oxides (NOx) and particulate matter (PM) emissions at congested and uncongested signalized intersections. The researchers used a time-in-mode analysis combining emissions factors for an activity mode (acceleration, deceleration, cruise, idle) with time spent in each mode. The emissions analysis paired MOVES with Synchro to conduct the traffic simulation. Results showed that acceleration was responsible for $46 \%$ to $55 \%$ of emissions, and cruising accounted for $28 \%$ to $47 \%$ of emissions. The authors conclude that uniform traffic flow is less sensitive to congestion than expected. In congested uniform traffic flow scenarios, cruise emissions were shown to increase while idling and acceleration emissions decreased. Managing control delay to minimize acceleration is important in reducing vehicle emissions. One limitation acknowledged by the study is the lack of validation for the emissions factors.

\subsubsection{Modeling Traffic Emissions Based on Vehicle Type and Driver Behavior}

Xie et al. (2010) modeled the emissions of alternatively fueled vehicles (electric, ethanol, and compressed natural gas) using MOVES and PARAMICS microsimulation software. The traffic model was calibrated and validated, and the outputs of PARAMICS were used as inputs for the MOVES software. The 
network consisted of a segment of Interstate-85 in Greenville, South Carolina. The comprehensive emissions analysis included meteorological information, vehicle age distribution, fuel formulation and supply, and link and link source type. The researchers found a mostly linear relationship between changes in vehicle fuel type to emissions reductions (e.g. switching $40 \%$ of transit from diesel to compressed natural gas represented $34 \%$ reduction in sulfur dioxide emissions). One limitation of the study is that the analysis segment was relatively short and did not consider other factors (acceleration, grades, congestion, etc.).

Ahn et al. (1998) estimated fuel consumption and emissions (CO, $\mathrm{HC}$, and $\mathrm{NO}_{\mathrm{x}}$ ) of light-duty vehicles and light-duty trucks using hybrid regression models. The motivation for the study stemmed from the limitations of existing urban models that only used average link speeds, whereas variances in acceleration and speed have a significant effect on fuel consumption and emissions. At the time, EPA's MOBILE6 software did not account for driver-related behaviors on emissions. The researchers collected speed and acceleration data from test vehicles at the Oak Ridge National Laboratory (ORNL). Emissions data obtained from the models were validated against real-world emissions data obtained from EPA's Automotive Testing Laboratories and National Vehicle and Fuels Emission Laboratory. Ahn et al. found that the model was consistent with real-world data with a coefficient of determination over 90 percent. 
2.2.5 Validation of Microscopic Traffic Simulation Models with Real Traffic Data

Calibration and validation of models remains an important final step to ensuring that the simulation model performs as expected and can generate reasonable data. Punzo and Simonelli (2005) tested four models of varying complexity against four test vehicles equipped with GPS receivers that recorded position at one tenth second intervals. Validation involved comparison of model results with test vehicle results using the same inputs. Punzo and Simonelli calibrated their results in which they attempted to reproduce a trajectory from vehicles 2, 3, and 4 by using parameters calibrated on the leader vehicle 1 . One limitation is that the leading vehicle has no knowledge of the preceding vehicle's trajectory. Punzo and Simonelli find that cross validations showed real world data to perform better using a Root Mean Square Percentage Error (RMSPe) when compared to data collected from a test track. When collecting real traffic data using a test vehicle, it is important to understand that validation may produce different errors even with the same driver. The authors suggest studying driver behavior over a long period of time to recognize how road and traffic characteristics can affect the driver, altering any perceived notions of a controlled study. Statistical measures for comparing results including root mean square error, root mean square percentage error, and Theil's Indicator ${ }^{2}$ were used as error testing for both calibration and validation. Conclusions highlighted the importance of real-world data for validation.

${ }^{2}$ Theil's Indicator $(U)$ provides a smooth, normalized error by reducing the impact of large errors. It is bounded according to $0 \leq U \leq 1$ where $U=0$ is a perfect fit, or no error. 
Helbing et al. (2002) present two traffic simulations models, a local, gas-kineticbased traffic model and a novel car-following model for use in congested systems. These models were calibrated and validated using data from Dutch freeway A9. They adjusted specific parameters in their model until reaching an optimal fit to the empirical data. They demonstrate that realistic simulation outputs can be obtained by adjusting certain parameters for speed, weather, and even time of day such as rush hour traffic with validation.

2.2.6 Analysis of MOVES and CMEM for Evaluating the Emissions Impacts of an Intersection Control Change

Chamberlin et al. (2011) compared two popular emissions simulators, MOVES and CMEM, by analyzing the emissions estimates based on a test-bed analysis of changing a 3-leg signalized intersection to a roundabout. $\mathrm{CO}$ and $\mathrm{NO}_{x}$ were chosen as the outputs for analysis. The microsimulation model used was Paramics. The model used the average speed and link drive schedule approaches in MOVES to generate emissions data. The link drive schedule uses a second-by-second speed profile for a vehicle. Chamberlin et al. found that CMEM estimates CO emissions at 4-6 times higher than MOVES (average speed and link drive schedule approaches), and NOx estimates are lower than the MOVES average speed approach but similar to the link drive approach. While the research does not definitively state which emissions estimator is more accurate or preferred, the authors describe in detail the greater capability of MOVES over CMEM. MOVES is capable of incorporating meteorological data and fuel type, and it relies on data from 62,500 dynamometer test vehicles as 
opposed to CMEM's 343 vehicles. MOVES can also model more pollutant processes than CMEM and uses statistical modeling of emissions using vehicle specific power and speed. CMEM only uses analytical modeling of the physical processes involving combustion, but it is well understood that fuel consumption and emissions are greatly affected by driver behavior. One limitation of the study is that neither the data from MOVES or CMEM was validated against real-world data.

\subsubsection{Discussion of Literature Surveyed}

Much research exists that estimate vehicle emissions on the aggregate and/or individual level using microsimulation software in conjunction with emissions modeling software. This paper benefits from the available research in that individual vehicle characteristics are being modeled to determine aggregate emissions on a corridor. The research shows that topography and roadway characteristics affect emissions. A 4\% grade can increase light-duty vehicle emissions from $15-20 \%$. Acceleration may account for as much as half of emissions while cruising may account for as little as a third. Validation with realworld traffic data was shown to differ from results obtained from test tracks or dynamometers, highlighting the importance of unforeseen variables that occur in the real world. Between the two major emissions models, MOVES and CMEM, MOVES has greater capability and relies on a larger library of test data than CMEM (62,500 vehicles vs. 343 vehicles). Hence, in this study we chose to use MOVES as the emissions estimator. It would facilitate future comparison with real-world data. 


\section{SIMULATION MODEL DEVELOPMENT FOR U.S. 101}

\subsection{AREA OF STUDY}

The study area includes the Cuesta Grade of U.S. 101 in San Luis Obispo

County. The northbound portion extends from the Monterey St on-ramp (milepost 29.985) in San Luis Obispo to the Junction 58 East (JCT 58) off-ramp (milepost 37.863) in Santa Margarita. The southbound portion extends from the JCT 58 onramp to the Monterey St off-ramp. Two models were created to show the beforeand-after comparison of the truck only lane on vehicle emissions. Both models include the Monterey and JCT 58 ramps and all stop controlled intersections in between. Operation on the Cuesta Grade is similar to a freeway even though it is technically a multilane highway due to very low volumes from the intersecting roads.

\subsubsection{U.S. Route 101}

U.S. 101 is a north-south highway that runs along the West Coast of the United States from California to Washington. It passes through several communities and cities in the Central Coast region of California. U.S. 101 varies in geometry but is generally 2 to 3 lanes in each direction. In California, the route connects the Central Coast region with the metropolitan regions of the San Francisco Bay Area and Los Angeles. 
The Cuesta Grade is a portion of the U.S. 101 extending beyond the northern city limits of San Luis Obispo, CA to Santa Margarita, CA (Figure 4).

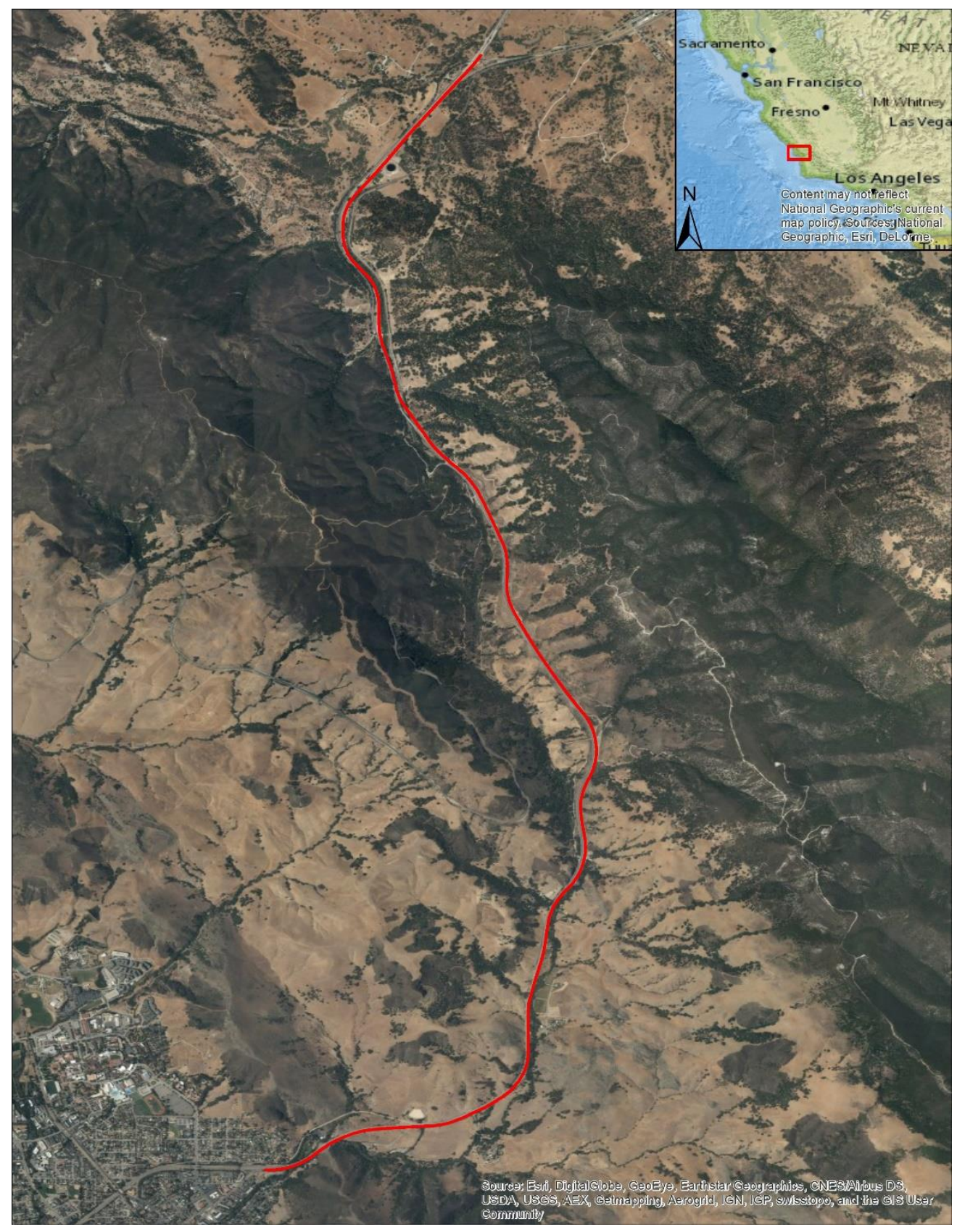

Figure 4. Cuesta grade aerial view 
It is a 4-lane limited-access highway with a posted speed limit of $65 \mathrm{mph}$ for cars and light trucks, and a 6-lane limited-access highway with a $35 \mathrm{mph}$ reduced speed limit for heavy goods vehicles (HGV) on the almost 3-mile steep grade section in the southbound direction. Historically, the highway was 4 lanes throughout the entire Cuesta Grade but was widened to 6 lanes. Widening construction started in 1999 and was completed on October 15, 2003. The purpose was to increase capacity as slow moving heavy vehicles on the steep grade often caused congestion (SLOCOG, 2003). Trucks are required to use these lanes and are restricted to a speed limit of $35 \mathrm{mph}$ in the southbound direction, but cars may also use these lanes and have no speed restrictions. According to the literature surveyed, this widening is expected to reduce sudden acceleration resulting in lower vehicle emissions. However, this would be opposite of what one might expect on the city streets. Widening on city streets may encourage greater acceleration and higher traffic volumes, increasing emissions.

The corridor has varying grades with a maximum elevation of 1,522 feet. There are six intersecting roads in the northbound direction (Fox Hollow Road, Reservoir Canyon Road, Vista Del Ciudad, Mt. Lowe Road, Forest Rte 30S11, and Tassajara Creek Road) and five major intersecting roads in the southbound direction (Tassajara Creek Road, Cuesta Springs Road, TV Tower Road, Old Stage Coach Road, and Miossi Road). Additionally, there are two egress only roads in the southbound direction (Old 101 and Hawk Hill Road). Traffic from 
these roads is limited, and the section operates similarly to a freeway. The PM peak hour is in the northbound direction.

This route serves mostly passenger cars and light trucks with some HGV. The San Luis Obispo Regional Transit Authority provides service via three routes that pass through the Cuesta Grade. Inclement weather includes heavy rain and dense fog during winter months.

\subsection{CREATING THE NETWORK}

\subsubsection{Before-and-After Comparison}

To analyze the emissions impact of widening from 4 to 6 lanes, two separate networks were created to represent past and present conditions. Each network has unique volumes, link geometry, and speed distributions. The first network (Network 1) uses data from 1998 to simulate conditions before widening of the Cuesta Grade began construction in 1999. The second network (Network 2) uses data from 2012 to essentially represent current conditions which is the most complete data available at the time from Caltrans.

\subsubsection{Road Network}

VISSIM includes satellite imagery from Microsoft's Bing Maps which was used as a basis for tracing the network. Links were created in segments along U.S. 101 with different grades assigned to each link. All links were assigned the standard lane width of 12 feet, and the HGV vehicle class is restricted to travel in lane 1. Network 1 uses a 4-lane network throughout the Cuesta Grade, and Network 2 represents the 6-lane portion from milepost 32.545 to 35.255 . Road grades were 
collected in the field starting at Reservoir Canyon Road and 3.35 miles northbound. The remaining grades were collected using Google Earth's elevation profile. Each of these grades were assigned to individual links. The complete network consists of 190 links and 199 connectors for a total of 389 links and connectors and can be found in Appendix A (Appendix A shows network 1 links, network 2 links similar with exception of number of lanes).

\subsubsection{Vehicle Data and Composition}

To create an accurate emissions model, the number of vehicles and its distribution are needed. Directional volumes from 1998 and 2012 were obtained from Caltrans. Ramp volumes provided by Caltrans are listed in ADT and were converted to peak hour using Equation 2.

$$
\text { Peak Hour Volume }=(A D T) *(K-\text { Factor })
$$

where:

$A D T$ : Annual daily traffic

K- Factor: Peak factor

Traffic volumes for the network were determined by studying ramp and highway volumes from Caltrans. A summary of the volume inputs for Networks 1 and 2 are shown in Tables 2 and 3. 
Table 2. Northbound Volume Inputs (Vehicles Per Hour)

\begin{tabular}{lcc}
\hline Road Link & Network 1 (4-lane) & Network 2 (6-lane) \\
\hline Monterey Street & 325 & 340 \\
NB 101 Start ${ }^{3}$ & 2,620 & 2,179 \\
Fox Hollow Road & 5 & 10 \\
Reservoir Canyon Road & 5 & 10 \\
Vista Del Ciudad Road & 5 & 10 \\
Cuesta Springs Road & 5 & 10 \\
Tassajara Creek Road & 15 & 20 \\
Old Stage Coach Road & 5 & 27 \\
\hline
\end{tabular}

Table 3. Southbound Volume Inputs (Vehicles Per Hour)

\begin{tabular}{lcc}
\hline Road Link & Network 1 (4-lane) & Network 2 (6-lane) \\
\hline Junction 58 East & 190 & 230 \\
SB 101 Start & & 1,865 \\
Tassajara Creek Road & 1,600 & 20 \\
Cuesta Springs Road & 20 & 15 \\
TV Road & 10 & 15 \\
Old Stage Coach Road & 15 & 13 \\
Hawk Hill Road & 13 & 11 \\
\hline
\end{tabular}

${ }^{3}$ These volumes represent existing input volumes on the highway. All other volumes in Tables 2 and 3 represent ramp volumes. 
The methodology for determining input volumes in VISSIM involved these steps:

1) For the northbound direction, use given total PM peak hour volume for the starting point of the network, immediately before the Monterey on-ramp.

2) The northbound volume is determined using the directional split (D Factor).

3) Convert on-ramp ADT to peak hour volumes using Equation 2 (see Assumptions for values used.)

4) Repeat steps 1-3 for southbound direction.

Vehicle compositions varied depending on the year of analysis. Caltrans reported $8 \%$ and $9 \%$ heavy trucks in 1998 and 2012, respectively, at milepost 30.360 (2016). 


\subsubsection{Speed Data}

VISSIM requires speed distributions to be defined for all vehicle classes. Speed survey data was not available for the Cuesta Grade, and the posted speed limit was used to determine speed distributions for the corridor. Three distributions were created to model the varying speed limits:

1) Cars and light trucks - Minimum speed of $55 \mathrm{mph}$, maximum speed of 75 $\mathrm{mph}, 15^{\text {th }}$ percentile speed of $60 \mathrm{mph}$, and $85^{\text {th }}$ percentile speed of 70 mph (Figure 5).

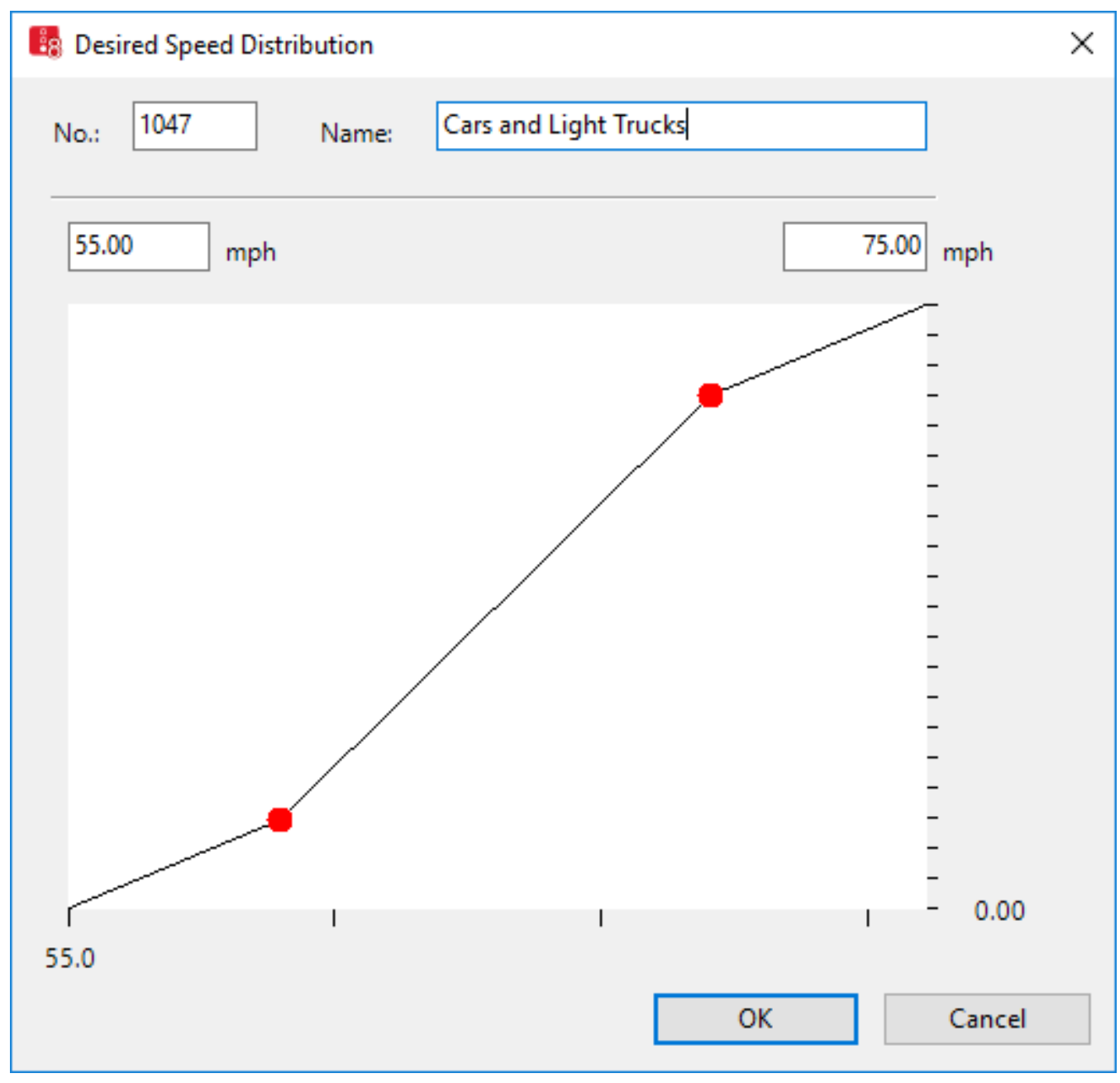

Figure 5. Speed distribution for cars and light trucks 
2) HGV - Minimum speed of $50 \mathrm{mph}$, maximum speed of $65 \mathrm{mph}, 15^{\text {th }}$ percentile speed of $55 \mathrm{mph}$, and $85^{\text {th }}$ percentile speed of $60 \mathrm{mph}$ (Figure $6)$.

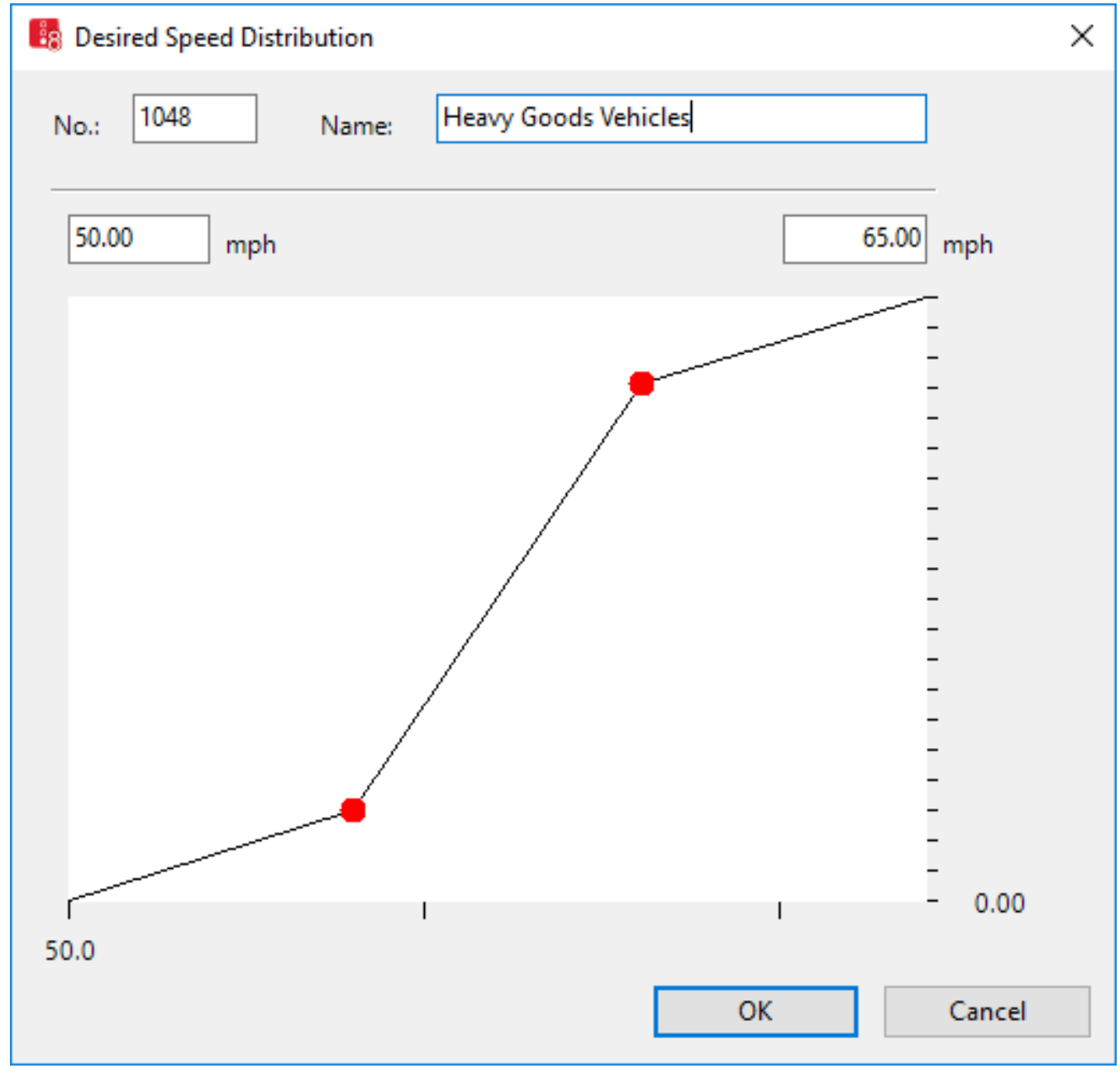

Figure 6. Speed distribution for heavy goods vehicles 
3) HGV (Reduced Speed Area) - Minimum speed of $25 \mathrm{mph}$, maximum speed of $40 \mathrm{mph}, 15^{\text {th }}$ percentile speed of $30 \mathrm{mph}$, and $85^{\text {th }}$ percentile speed of $35 \mathrm{mph}$ (Figure 7).

a. The reduced speed area is in effect only between mileposts 32.545 and 35.255 for Network 2.

b. There is no reduced speed area in effect for the northbound direction for either network.

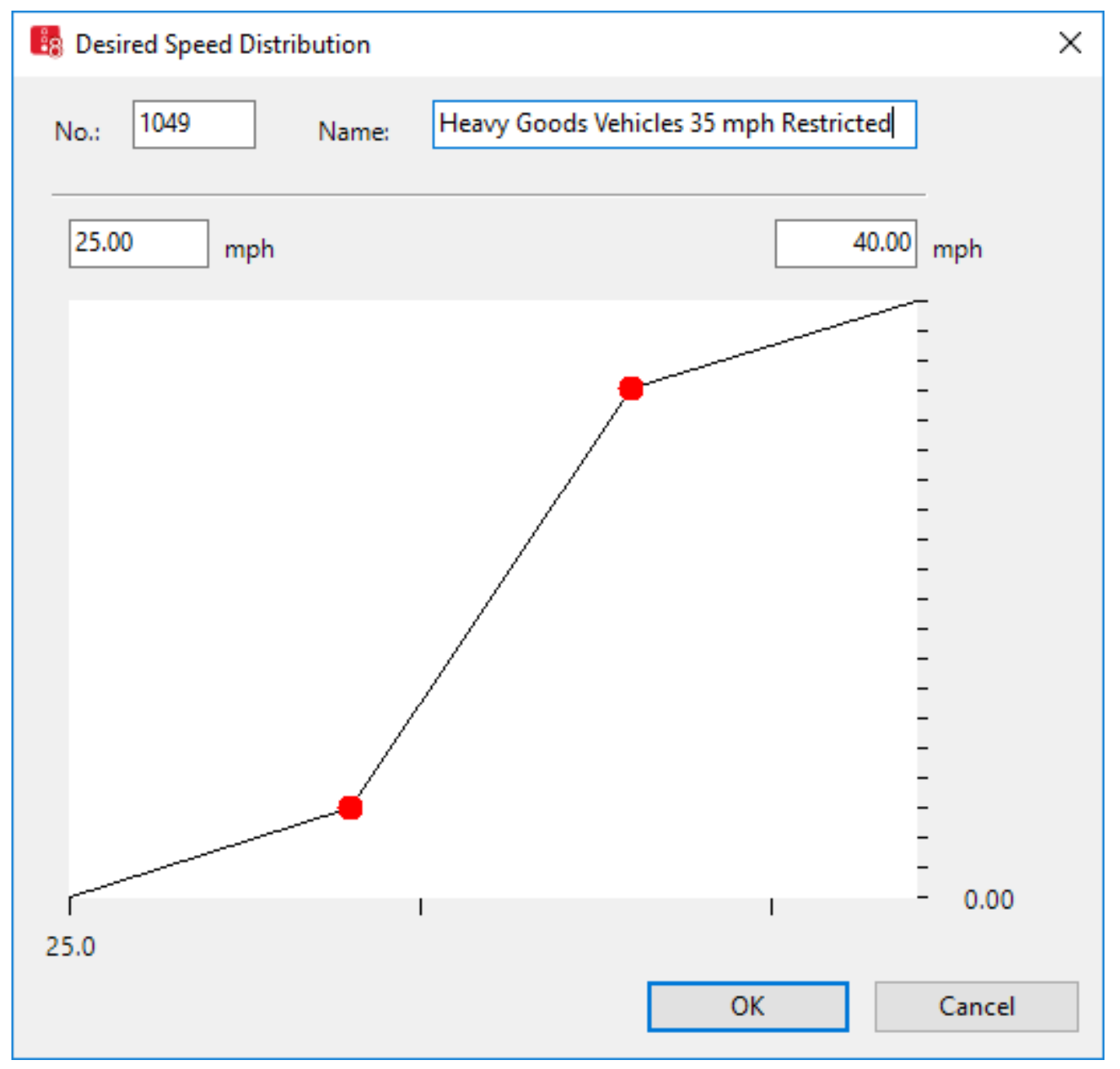

Figure 7. Speed distribution for reduced speed area for HGV 


\subsubsection{Stop Signs and Conflict Areas}

Because the Cuesta Grade is a limited-access highway, several stop-controlled intersections were modeled. Stop signs and conflict areas were assigned to these intersecting roads. Vehicles stop once at the stop sign, move forward, check for potential conflicts, and then finally merge onto the highway. Dwell time distributions for stop signs were not assigned because vehicles are assumed to immediately proceed after stopping when they find a reasonable gap. Conflict areas assigned to merge points prevent vehicles from colliding.

\subsubsection{Data Collection Points}

In VISSIM, data collectors were placed at strategic locations to collect speed, acceleration, and volumes for both vehicle classes. Data collection points were first placed on each link (in the case of two lanes, one for each lane), and data collection measurements were further defined by specifying the data collection points. For example, the "NB 101 After Monterey" data collection measurement collected data from data collection points 7 and 8 (one for each lane). Figure 8 illustrates each data collection measurement location. These data collection locations were included to ensure that requisite data for emissions estimation were available. 


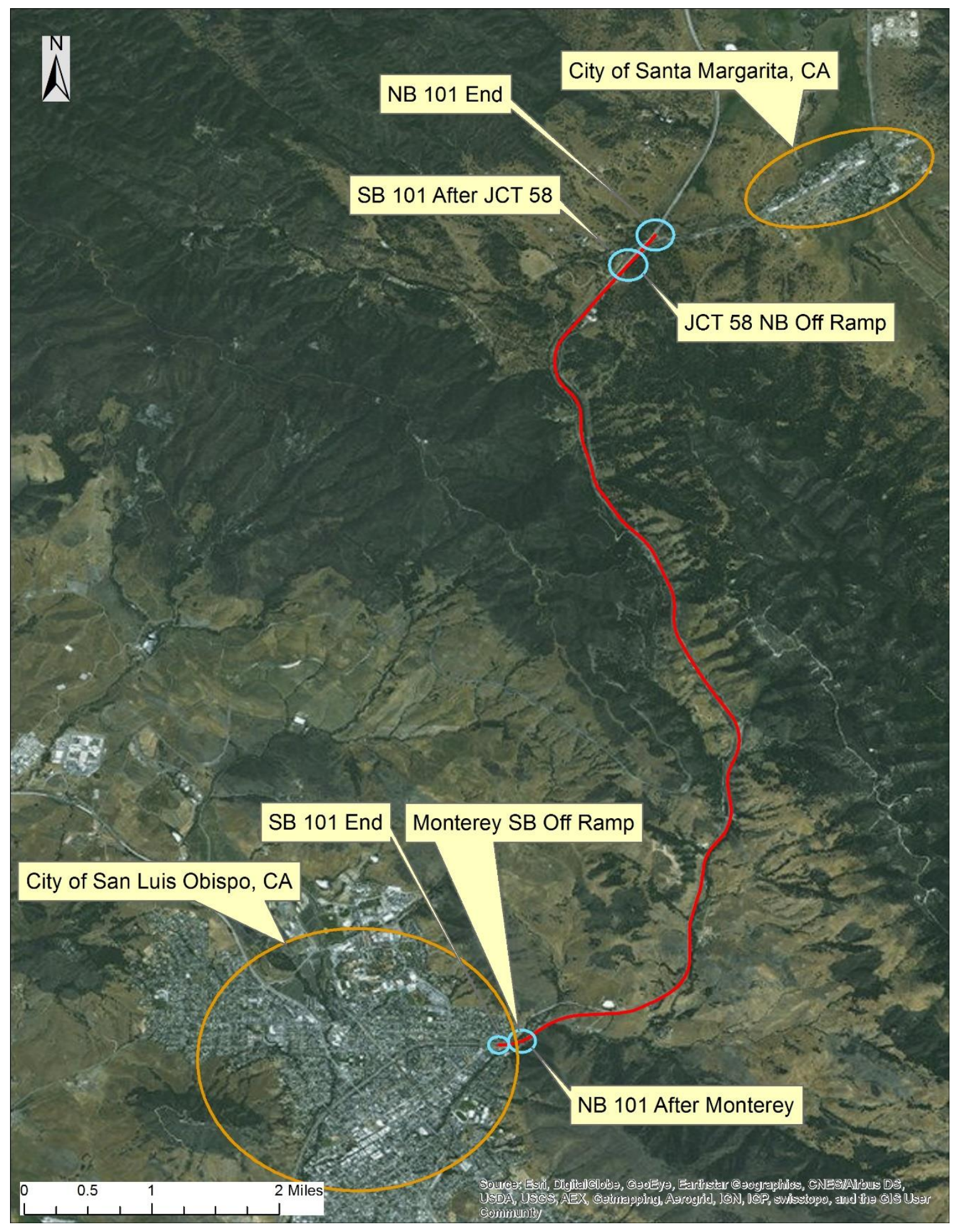

Figure 8. Locations of data collection measurement points 


\subsubsection{Emissions Modeling}

Emissions data were gathered by exporting the simulation results from VISSIM and importing into MOVES software. The data inputs for MOVES include link length, grade, vehicle composition, volume, and vehicle trajectory data which include speed, and acceleration on a link by link basis. Grades were also obtained from field data on a link by link basis. Vehicle composition was obtained from Caltrans and simulated in VISSIM. All other inputs (volume, speed, and acceleration) were separated by vehicle type. All data was then aggregated into 3 sections: before truck lane, truck lane, and after truck lane to compare the effects at each section in 1998 and 2012. Data was not directly collected in the middle section (truck lane) because there was no real traffic data to validate the results. The volumes, speeds, and acceleration used as input for the middle section was the average of the before truck lane and after truck lane values. VIMIS, a custom software package developed by Hatem et al. (2013), was used to integrate between VISSIM and MOVES. This software converts VISSIM files to MOVES files so that emissions estimates can be generated.

\subsubsection{Assumptions}

Real-world traffic conditions are intricate systems and very difficult to perfectly replicate in simulation. Not all data can be reasonably collected for use in a simulation model. Models and the resulting calibration/validation rely on assumptions to fill these gaps. The VISSIM model being developed for this study relies on the following assumptions: 
- Area of Study is limited to the Cuesta Grade on U.S. 101 (milepost 29.985 to milepost 37.863 ) and intersecting roads that do not dead-end to small properties which may not have significant traffic volumes.

- Time of Study is limited to the PM peak period (5:00 - 6:00 PM).

- Time of Simulation is limited to 70 minutes. A 10-minute time period is used as a warm-up for the simulation.

- Vehicle Composition is limited to cars, light trucks, and HGV. Vehicles were not further sub-classified within their vehicle type (i.e. sedans and SUVs are considered to be the cars and light trucks type, respectively). Motorcyclists and regional transit were not included in the model.

- Traffic Inputs have several key assumptions:

- Peak hour volumes may not have been collected during the midweek (Tuesday - Thursday) due to lack of available data.

- D Factors were adjusted to match the same peak hour of data collection ( $60 \%$ for $1998,55 \%$ for 2012$)$.

- Ramp volumes are provided in ADT and converted to peak hour volume using an assumed $\mathrm{K}$ Factor of $10 \%$.

- Traffic volumes were not available for the stop-controlled intersections along the Cuesta Grade corridor. These values were assumed to be between 5-30 vehicles per hour.

- Speed Distributions were assumed to be a range based on the posted speed limit and varied between vehicle classes.

- Unless otherwise specified, VISSIM's default parameters are assumed. 


\subsection{ORIGIN-DESTINATION MATRIX}

An origin-destination matrix (OD matrix) is used to determine where vehicles enter and exit throughout the model. Given the known starting and ending volumes of the Cuesta Grade, assumptions were made for traffic volumes of these stop-controlled intersections. Appendix B shows the OD matrices for the northbound and southbound directions for each network. 


\section{DATA ANALYSIS AND RESULTS}

\subsection{CALIBRATION AND VALIDATION}

\subsubsection{Calibration Parameters}

Calibration and validation are important steps to ensure accuracy of the model. The model was calibrated several times until validation showed acceptable level of discrepancy between real and simulated volumes. The data that is known includes the starting and ending volumes of the network. The unknown data includes all volumes in between at the stop-controlled intersections. The model was continually calibrated until validation measures (including GEH statistic) were satisfactory.

\subsubsection{Validation}

To validate the model, the output data was analyzed and compared to available traffic counts from Caltrans. Several validation techniques were used including the GEH statistic, Root Mean Squared Error (RMSE), and Theil's Indicator.

\subsubsection{GEH Statistic}

The GEH Statistic is a formula commonly used to compare two sets of hourly traffic volumes. It was derived empirically by Geoffrey E. Havers in the 1970 s and is defined by Equation 3:

$$
G E H=\sqrt{\frac{2(M-C)^{2}}{M+C}}
$$

where:

M: Traffic model hourly count 


\section{C: Real-world hourly count}

It is generally accepted that values less than 5 to have low chance of error, between 5 and 10 medium chance of error, and greater than 10 high chance of error (Wisconsin Department of Transportation, 2014).

\subsubsection{Root Mean Squared Error}

The root mean squared error represents the distance of a data point from a fitted line. In this case, the fitted line would be the real-world data, and the data point would be the simulation count. RMSE is bounded between $0-1$ with 0 representing no error. It is defined by Equation 4:

$$
R M S E=\sqrt{\frac{\sum_{i=1}^{n}\left(\hat{y}_{i}-y_{i}\right)^{2}}{n}}
$$

where:

$y_{i}$ : Traffic model hourly count

$\hat{y}_{i}:$ Real-world hourly count

$\mathrm{n}$ : Number of observations

\subsubsection{Theil's Indicator}

Theil's Indicator is used as a measure of forecast accuracy bounded between 0 1 with 0 representing perfect forecast. It is defined by equation 5 :

$$
U=\frac{\left[\frac{1}{n} \sum_{i=1}^{n}\left(A_{i}-P_{i}\right)^{2}\right]^{\frac{1}{2}}}{\left[\frac{1}{n} \sum_{i=1}^{n} A_{i}^{2}\right]^{\frac{1}{2}}+\left[\frac{1}{n} \sum_{i=1}^{n} P_{i}^{2}\right]^{\frac{1}{2}}}
$$

where:

$n$ : Number of observations 
$A_{i}$ : Actual observations

$P_{i:}$ Predictions

Each validation measure's satisfactory thresholds are summarized in Table 4.

Table 4. Validation Measures and Thresholds

Validation Measure

GEH Statistic

Root Mean Squared Error

Theil's Indicator

\section{Threshold}

5.0

$0-1$

$0-1$

\subsection{TRAFFIC VOLUMES}

A total of 5 simulations were run with the results averaged together. The seed numbers used for the simulation were $18,23,28,33$, and 38 . The results of the simulation are shown in Tables 5 and 6 . A full results output from VISSIM can be found in Appendix C. Volumes were much less in the southbound direction in 1998, while volumes were generally the same in the northbound direction during both time periods. At the beginning of the northbound direction, volumes were $18.8 \%$ greater in 1998 vs. 2012 . Validation measures revealed acceptable numbers for all data points.

Table 5. Network 1 (4-lane) Traffic Volume Results

\begin{tabular}{|c|c|c|c|c|c|c|c|}
\hline & NB 101 & JCT & NB & SB & Monterey & SB & Truck \\
& After & 58 & 101 & 101 & SB Off & 101 & Percentage \\
& Monterey & NB & End & After & Ramp & End & \\
\hline
\end{tabular}




\begin{tabular}{|c|c|c|c|c|c|c|c|}
\hline & & $\begin{array}{c}\text { Off } \\
\text { Ramp }\end{array}$ & & $\begin{array}{c}\mathrm{JCT} \\
58\end{array}$ & & & \\
\hline Expected Counts & 2940 & 190 & 2385 & 1795 & 325 & 1470 & $8 \%$ \\
\hline Simulation Counts & 2918.6 & 196 & 2383.6 & 1785.4 & 323 & 1429.4 & $8.7 \%$ \\
\hline GEH Statistic & 0.40 & 0.43 & 0.03 & 0.23 & 0.11 & 1.07 & -- \\
\hline Theil's Indicator & 0.00 & 0.04 & 0.01 & 0.02 & 0.03 & 0.02 & -- \\
\hline RMSE & 0.01 & 0.08 & 0.02 & 0.03 & 0.06 & 0.04 & -- \\
\hline
\end{tabular}

Table 6. Network 2 (6-lane) Traffic Volume Results

\begin{tabular}{|c|c|c|c|c|c|c|c|}
\hline & $\begin{array}{c}\text { NB } 101 \\
\text { After } \\
\text { Monterey }\end{array}$ & $\begin{array}{c}\text { JCT } \\
58 \\
\text { NB } \\
\text { Off } \\
\text { Ramp }\end{array}$ & $\begin{array}{l}\text { NB } \\
101 \\
\text { End }\end{array}$ & $\begin{array}{c}\text { SB } \\
101 \\
\text { After } \\
\text { JCT } \\
58\end{array}$ & $\begin{array}{c}\text { Monterey } \\
\text { SB Off } \\
\text { Ramp }\end{array}$ & $\begin{array}{l}\text { SB } \\
101 \\
\text { End }\end{array}$ & $\begin{array}{c}\text { Truck } \\
\text { Percentage }\end{array}$ \\
\hline Expec & 2475 & 188.6 & 2386.4 & 2151 & 336.3 & 1814.7 & $9 \%$ \\
\hline Simulation Counts & 2500.2 & 182 & 2358 & 2098 & 335 & 1778.6 & $8.9 \%$ \\
\hline GEH Statistic & 0.51 & 0.48 & 0.58 & 1.15 & 0.07 & 0.85 & -- \\
\hline Theil's Indicator & 0.01 & 0.03 & 0.01 & 0.02 & 0.02 & 0.02 & -- \\
\hline RMSE & 0.01 & 0.06 & 0.03 & 0.03 & 0.05 & 0.03 & 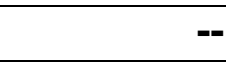 \\
\hline
\end{tabular}

\subsection{EMISSIONS RESULTS}

Averaging the 5 simulation runs in VISSIM, the aggregated data used as MOVES inputs are shown in Table 7, and emissions results are shown in Table 8. Across the whole corridor, results show that total $\mathrm{CO}_{2}$ emissions were lower in the northbound direction for 2012 and higher for the southbound direction for both study periods, except that the truck lane in the southbound direction showed a $7.4 \%$ decrease in emissions. Overall, $\mathrm{CO}_{2}$ emissions decreased by $6.8 \%$ across the whole corridor. 
Table 7. Inputs for MOVES Emissions Modeling

\begin{tabular}{|c|c|c|c|c|c|c|c|c|c|c|}
\hline \multirow[b]{3}{*}{ Direction } & \multicolumn{5}{|c|}{ Network 1 (4-lane): 1998 Data } & \multicolumn{5}{|c|}{ Network 2 (6-lane): 2012 Data } \\
\hline & \multirow[b]{2}{*}{ Section } & \multirow{2}{*}{$\begin{array}{c}\text { Total } \\
\text { Volume }\end{array}$} & \multicolumn{2}{|c|}{ Average Speed (mph) } & \multirow{2}{*}{$\begin{array}{c}\text { Truck } \\
\text { Percentage }\end{array}$} & \multirow[b]{2}{*}{ Section } & \multirow{2}{*}{$\begin{array}{c}\text { Total } \\
\text { Volume }\end{array}$} & \multicolumn{2}{|c|}{ Average Speed (mph) } & \multirow{2}{*}{$\begin{array}{c}\text { Truck } \\
\text { Percentage }\end{array}$} \\
\hline & & & Cars & Trucks & & & & Cars & Trucks & \\
\hline \multirow{3}{*}{$\begin{array}{l}\text { Northbound } \\
\text { (Uphill) }\end{array}$} & Before Truck Lane & 2919 & 60.06 & 51.24 & 8.70 & Before Truck Lane & 2500 & 61.12 & 52.06 & 8.92 \\
\hline & Truck Lane & 2770 & 46.31 & 21.23 & 8.74 & Truck Lane & 2530 & 60.96 & 21.39 & 8.93 \\
\hline & After Truck Lane & 2384 & 60.26 & 54.17 & 8.10 & After Truck Lane & 2330 & 60.19 & 54.81 & 8.71 \\
\hline \multirow{3}{*}{$\begin{array}{l}\text { Southbound } \\
\text { (Downhill) }\end{array}$} & Before Truck Lane & 1785 & 63.37 & 56.17 & 8.29 & Before Truck Lane & 2098 & 63.20 & 55.61 & 9.01 \\
\hline & Truck Lane & 1761 & 61.67 & 30.58 & 8.18 & Truck Lane & 2118 & 63.27 & 30.35 & 8.97 \\
\hline & After Truck Lane & 1429 & 63.12 & 55.95 & 8.05 & After Truck Lane & 1779 & 62.44 & 55.80 & 8.66 \\
\hline
\end{tabular}

Table 8. MOVES Emissions Estimates

\begin{tabular}{|c|c|c|c|c|c|c|c|c|}
\hline \multirow[b]{2}{*}{ Direction } & \multicolumn{3}{|c|}{ Network 1 (4-lane): 1998 Data } & \multicolumn{3}{|c|}{ Network 2 (6-lane): 2012 Data } & \multicolumn{2}{|c|}{$\%$ Change } \\
\hline & Section & Length (mi) & $\mathrm{CO}_{2}(\mathrm{~kg})$ & Section & Length (mi) & $\mathrm{CO}_{2}(\mathrm{~kg})$ & Emissions & Volume \\
\hline \multirow{4}{*}{$\begin{array}{l}\text { Northbound } \\
\text { (Uphill) }\end{array}$} & Before Truck Lane & 2.6 & 5485 & Before Truck Lane & 2.6 & 4689 & -17.0 & -16.8 \\
\hline & Truck Lane & 2.75 & 8445 & Truck Lane & 2.75 & 7627 & -10.7 & -9.5 \\
\hline & After Truck Lane & 2.47 & 3110 & After Truck Lane & 2.47 & 3021 & -2.9 & -2.3 \\
\hline & TOTAL $\mathrm{CO}_{2}$ & 7.82 & 17040 & TOTAL $\mathrm{CO}_{2}$ & 7.82 & 15337 & -11.1 & -- \\
\hline \multirow{5}{*}{$\begin{array}{l}\text { Southbound } \\
\text { (Downhill) }\end{array}$} & Before Truck Lane & 2.47 & 3647 & Before Truck Lane & 2.47 & 3750 & +2.8 & +17.5 \\
\hline & Truck Lane & 2.75 & 3635 & Truck Lane & 2.75 & 3386 & -7.4 & +20.3 \\
\hline & After Truck Lane & 2.6 & 2128 & After Truck Lane & 2.6 & 2301 & +8.1 & +24.5 \\
\hline & TOTAL $\mathrm{CO}_{2}$ & 7.82 & 9410 & TOTAL $\mathrm{CO}_{2}$ & 7.82 & 9437 & +0.3 & -- \\
\hline & TOTAL CORRIDOR $\mathrm{CO}_{2}$ & & 26450 & TOTAL CORRIDOR $\mathrm{CO}_{2}$ & & 24774 & -6.8 & -- \\
\hline
\end{tabular}




\subsection{DISCUSSION}

Northbound emissions decreased by $10.7 \%$, and volumes decreased by $9.5 \%$ in the truck only lane portion. Southbound emissions decreased by $7.4 \%$, although volumes increased by $20.3 \%$ in the same section. While the results showed increased emissions in the northbound direction and decreased emissions in the southbound direction, it is important to note that other factors may have influenced the results. The most apparent is the change in volumes in the northbound direction. However, the southbound emissions reduction was also attributed to the down grade section. Table 8 shows a general correlation between volume and emissions for the northbound direction. In the southbound direction, volume appears less influential on emissions. Southbound emissions may be less sensitive to volume changes because drivers are cruising downhill rather than accelerating uphill. There has been a posted truck speed limit of 35 mph since at least 1998 for this section of road due to the steep grade. Drivers stuck behind trucks in a 2-lane road may accelerate upon passing slow moving trucks, and prior research has shown that acceleration can account for up to half of vehicle emissions (Papson et al., 2012). 


\section{CONCLUSIONS}

\subsection{SUMMARY}

This thesis sought to estimate $\mathrm{CO}_{2}$ emissions on a limited-access highway before and after the addition of a truck only lane using a microsimulation tool, VISSIM, with an emissions estimator, MOVES. The data obtained from this research seem to indicate that the truck only lane reduced $\mathrm{CO}_{2}$ emissions along the Cuesta Grade. One factor to be accounted for is the change in volume which seems to play a much larger role in emissions than roadway features or topography. Additionally, vehicle speeds have a high influence on $\mathrm{CO}_{2}$ emissions. The truck only lane may be beneficial in situations with high congestion causing vehicles to behave more erratically than cruising smoothly.

\subsection{LIMITATIONS}

Some limitations of this study should be noted. The car-following model used in VISSIM has been shown in one study to be less accurate than field data, and this thesis did not explore the use of field data to calibrate/validate the simulation model. The literature review highlights the importance of validation against realworld data. Although there is a posted truck speed limit of $35 \mathrm{mph}$ in the southbound (downhill) section, there is no posted limit for trucks in the northbound direction. Due to steep uphill grade in the northbound direction the trucks are traveling slowly regardless of the speed limit. It was apparent in the simulation setting by running two separate simulations for the northbound direction with and without this northbound speed restriction. The truck speed 
distribution from both simulations showed that there is no significant difference in the travel speed with trucks traveling no more than $22 \mathrm{mph}$ on average (see Appendix C).

\subsection{FUTURE SCOPE}

While this thesis was an attempt to comprehensively quantify $\mathrm{CO}_{2}$ emissions before and after the addition of a truck only lane, limitations discussed above should be addressed in future work. VISSIM and MOVES were both used to create the network and estimate emissions. A comparison of different software packages could strengthen this research when compared to real-world data. Estimating emissions for different truck speeds should also be explored as speeds are known to greatly influence emissions. A test vehicle equipped with a probe to conduct in-situ measurements would provide greater insight into the accuracy of these emissions estimators. Other emissions should be compared too - such as those described in Section 1 (carbon monoxide, lead, nitrogen dioxide, ozone, particulate pollution, and sulfur dioxide). Additional work could explore the non-peak period to determine the effect, if any, on vehicle emissions. 


\section{BIBLIOGRAPHY}

Abou-Senna, H., Radwan, E., Westerlund, K., \& Cooper, C.D. (2013). Using a traffic simulation model (VISSIM) with an emissions model (MOVES) to predict emissions from vehicles on a limited-access highway, Journal of the Air \& Waste Management Association, 63(7), 819-831. doi: 10.1080/10962247.2013.795918.

Ahn, K., Rakha, H., Trani, A., \& Aerde, M. V. (2002). Estimating Vehicle Fuel Consumption and Emissions based on Instantaneous Speed and Acceleration Levels, Journal of Transportation Engineering, 128(2), 182190.

Barth, M., Collins, J., Scora, G., Davis, N., \& Norbeck, J. (2005). Measuring and Modeling Emissions from Extremely Low Emitting Vehicles. Paper presented at Transportation Research Board 2006. Washington, D.C.

Barth, M., Scora, G., \& Younglove, T. (2014). Model Emissions Model for HeavyDuty Diesel Vehicles, Transportation Research Record: Journal of the Transportation Research Board, 1880(1), 10-20. doi: http://dx.doi.org/10.3141/1880-02

Bliemel, F. (1973). Theil's Forecast Accuracy Coefficient: A Clarification, Journal of Marketing Research, X, 444-446.

Boriboonsomsin, K. \& Barth, M. (2009). Impacts of Road Grade on Fuel Consumption and Carbon Dioxide Emissions Evidenced by Use of Advanced Navigation Systems, Transportation Research Record: Journal of the Transportation Research Board, 2139, 21-30. doi: 10.3141/2139-03.

Caltrans. (2016). Traffic Census Program. Retrieved from http://www.dot.ca.gov/trafficops/census/

Chu, H. \& Meyer, M.D. (2009). Methodology for assessing emission reduction of truck-only toll lanes, Energy Policy, 37, 3287-3294.

Cicero-Fernândez, P., Long, J.R., \& Winer, A. M. (2011). Effects of Grades and Other Loads on On-Road Emissions of Hydrocarbons and Carbon Monoxide, Journal of the Air \& Waste Management Association, 47(8), 898-904. doi:10.1080/10473289.1997.10464455.

Chamberlin, R., Swanson, B., Talbor, E., Dumont, J., \& Pesci, S. (2010). Analysis of MOVES and CMEM for Evaluating the Emissions Impacts of an Intersection Control Change. Paper presented at Transportation Research Board 2011. Washington, D.C. 
Chamberlin, R., Swanson, B., Talbot, E., Sharma, S., \& Crouch, P. (2011).

Toward Best Practices for Conducting a MOVES Project-Level Analysis.

Paper presented at Transportation Research Board 2012. Washington, D.C.

Environmental Protection Agency (EPA). (2015). Inventory of U.S. Greenhouse Gas Emissions and Sinks: 1990-2013.

Environmental Protection Agency (EPA). (2014). Sources of Greenhouse Gas Emissions. Retrieved from

https://www3.epa.gov/climatechange/ghgemissions/sources/transportation .html

Environmental Protection Agency (EPA). (2015, November). MOVES2014a User Guide. Retrieved from https://nepis.epa.gov/Exe/ZyPDF.cgi?Dockey=P100NNCY.txt

Green, D. L. \& Schafer, A. (2003, May). Reducing Greenhouse Gas Emissions From U.S. Transportation. Retrieved from http://www.c2es.org/docUploads/ustransp.pdf

Helbing, D., Hennecke, A., Shvetsov, V., \& Treiber, M. (2002). Micro- and MacroSimulation of Freeway Traffic, Mathematical and Computer Modelling, 35, 517-547.

Helbing, D. \& Molnár, P. (1995). Social Force Model for Pedestrian Dynamics, The American Physical Society, 51(5).

Intergovernmental Panel on Climate Change (2014). Climate Change 2014 Synthesis Report Summary for Policymakers. Retrieved from http://www.ipcc.ch/pdf/assessmentreport/ar5/syr/AR5_SYR_FINAL_SPM.pdf

Jain, S., Creasey, R.R., Himmelspach, J., White, K. P., \& Fu, M. (Eds.). (2011). Proceedings of the 2011 Winter Simulation Conference: Introductory Tutorial: Agent-Based Modeling and Simulation. Argonne, IL.

Kilbert, S. M. (2011). A Microsimulation of Traffic, Parking, and Emissions at California Polytechnic State University - San Luis Obispo (Master's thesis, California Polytechnic State University, San Luis Obispo). Retrieved from http://digitalcommons.calpoly.edu/theses/452/.

Maness, H. L., Thurlow, M. E., McDonald, B. C., \& Harley, R. A. (2015). Estimates of $\mathrm{CO} 2$ traffic emissions from mobile concentration measurements, Journal of Geophysical Research: Atmospheres, 120. doi:10.1002/2014JD022876. 
Nam, E. K., Gierczak, C. A., \& Butler, J. W. (2002). A Comparison Of Real-World and Modeled Emissions Under Conditions of Variable Driver Aggressiveness. Paper presented at Transportation Research Board 2003. Washington, D.C.

Panwai, S. \& Dia, H. (2005). Comparative evaluation of microscopic car-following behavior, IEEE Transactions on Intelligent Transportation Systems, 6(3), 314-325. doi:10.1109/TITS.2005.853705.

Papson, A., Hartley, S., \& Kuo, K. (2011). Analysis of Emissions at Congested and Uncongested Intersections Using MOVES2010. Paper presented at Transportation Research Board 2012. Washington, D.C.

Punzo, V. \& Simonelli, F. (2005). Analysis and comparison of microscopic traffic flow models with real traffic microscopic data, Transportation Research Record, 1934, 53-63.

San Luis Obispo County of Governments (SLOCOG). (2003, October). Cuesta Grade Project Completed. Retrieved from: http://www.slocog.org/sites/default/files/newsletter/Oct03\%20newsletter.pd f

Song, G., Yu, L., \& Zhang, Y. (2012). Applicability of Traffic Microsimulation Models in Vehicle Emissions Estimates, Transportation Research Record: Journal of the Transportation Research Board, 2270, 132-141. doi:10.3141/2270-16.

Xie, Y., Chowdhury, M., Bhavsar, P., \& Zhou, Y. (2010). An Integrated Tool for Modeling the Impact of Alternative Fueled Vehicles on Traffic Emissions: A Case Study of Greenville, South Carolina. Paper presented at Transportation Research Board 2011. Washington, D.C.

Wiedemann, R. (1974). Simulation des Strassenverkehrsflusses. Schriftenreihe des Instituts für Verkehrswesen der Universität Karlsruhe, Band 8, Karlsruhe, Germany.

Wisconsin Department of Transportation. (2014). Model Calibration. Retrieved from: http://www.wisdot.info/microsimulation/index.php?title=Model_Calibration 


\section{APPENDICES}

\section{APPENDIX A: LIST OF VISSIM LINKS AND GRADIENTS (NETWORK 1)}

\$VISION

${ }^{*}$ File:

* Comment:

* Date:

$10 / 24 / 201613: 30$

* PTV Vissim:

$8.00[09]$

* Table: Links

* NO: No, Number (Unique number of the link or connector)

* NAME: Name, Name (Name of the link or connector)

* NUMLANES: NumLanes, Number of lanes (Number of lanes. The table in the Lanes tab is automatically adjusted.)

* LENGTH2D: Length2D, Length 2D (Length of the link without considering height) [ft]

* GRADIENT: Gradient, Gradient (Uphill and downhill slopes of the connector in percent. Downhill slopes have a negative value.

The value impacts the driving behavior via the maximum acceleration and maximum deceleration:

by $-0.1 \mathrm{~m} / \mathrm{s}^{2}$ per gradient percent incline. The maximum accelerating power decreases when the deceleration power increases.

by $0.1 \mathrm{~m} / \mathrm{s}^{2}$ per gradient percent downgrade. The accelerating power increases when the deceleration power decreases.)

*

${ }^{*}$ No

Name

NumLanes Length2D

Gradient

\begin{tabular}{|c|c|c|c|c|}
\hline \$LINK:NO & NAME & NUMLANES & LENGTH2D & GRADIENT \\
\hline 1 & NB_Grade_1 & 2 & 223.36 & $1.00 \%$ \\
\hline 2 & NB_Grade_2 & 2 & 248.36 & $0.20 \%$ \\
\hline 3 & NB_Grade_3 & 2 & 248.36 & $3.68 \%$ \\
\hline 4 & NB_Grade_4 & 2 & 248.36 & $3.66 \%$ \\
\hline 5 & NB_Grade_5 & 2 & 198.36 & $4.16 \%$ \\
\hline 6 & NB_Grade_6 & 2 & 348.36 & $2.48 \%$ \\
\hline 7 & NB_Grade_7 & 2 & 198.36 & $1.08 \%$ \\
\hline 8 & NB_Grade_8 & 2 & 1048.36 & $1.84 \%$ \\
\hline
\end{tabular}




\begin{tabular}{|r|l|r|r|r|} 
& NB_Grade_9 & 2 & 223.36 & $1.84 \%$ \\
\hline 10 & NB_Grade_10 & 2 & 173.36 & $1.56 \%$ \\
\hline 11 & NB_Grade_11 & 2 & 248.36 & $1.88 \%$ \\
\hline 12 & NB_Grade_12 & 2 & 548.36 & $2.43 \%$ \\
\hline 13 & NB_Grade_13 & 2 & 198.36 & $3.36 \%$ \\
\hline 14 & NB_Grade_14 & 2 & 448.36 & $2.38 \%$ \\
\hline 15 & NB_Grade_15 & 2 & 1098.36 & $1.40 \%$ \\
\hline 16 & NB_Grade_16 & 2 & 273.36 & $1.40 \%$ \\
\hline 17 & NB_Grade_17 & 2 & 423.36 & $2.60 \%$ \\
\hline 18 & NB_Grade_18 & 2 & 348.36 & $2.52 \%$ \\
\hline 19 & NB_Grade_19 & 2 & 273.36 & $2.88 \%$ \\
\hline 20 & NB_Grade_20 & 2 & 273.36 & $2.52 \%$ \\
\hline 21 & NB_Grade_21(1) & 2 & 249.582 & $4.12 \%$ \\
\hline 22 & NB_Grade_21(2) & 3 & 93.36 & $4.12 \%$ \\
\hline 23 & NB_Grade_22 & 3 & 123.36 & $5.00 \%$ \\
\hline 24 & NB_Grade_23 & 3 & 148.091 & $6.11 \%$ \\
\hline 25 & NB_Grade_24 & 3 & 198.36 & $7.08 \%$ \\
\hline 26 & NB_Grade_25 & 3 & 598.534 & $7.36 \%$ \\
\hline 27 & NB_Grade_26 & 3 & 198.36 & $7.16 \%$ \\
\hline 28 & NB_Grade_27 & 3 & 23.36 & $7.16 \%$ \\
\hline 29 & NB_Grade_28 & 3 & 133.36 & $7.00 \%$ \\
\hline 30 & NB_Grade_29 & 3 & 448.36 & $7.48 \%$ \\
\hline 31 & NB_Grade_30 & 3 & 483.36 & $7.12 \%$ \\
\hline 32 & NB_Grade_31 & 3 & 588.36 & $7.56 \%$ \\
\hline 33 & NB_Grade_32 & 3 & 418.36 & $6.85 \%$ \\
\hline 34 & NB_Grade_33 & 3 & 918.36 & $7.40 \%$ \\
\hline 35 & NB_Grade_34 & 3 & 1838.36 & $6.96 \%$ \\
\hline 36 & NB_Grade_35 & 3 & 1158.36 & $6.96 \%$ \\
\hline 37 & NB_Grade_36 & 3 & 538.36 & $7.40 \%$ \\
\hline 38 & NB_Grade_37 & 3 & 1248.36 & $7.12 \%$ \\
\hline 39 & NB_Grade_38 & 3 & 918.36 & $6.64 \%$ \\
\hline 40 & NB_Grade_39 & 3 & 498.36 & $7.68 \%$ \\
\hline & & & \\
\hline
\end{tabular}




\begin{tabular}{|r|l|r|r|r|} 
& NB_Grade_40 & 3 & 498.36 & $6.98 \%$ \\
\hline 42 & NB_Grade_41 & 3 & 498.36 & $6.05 \%$ \\
\hline 43 & NB_Grade_42 & 3 & 498.36 & $6.28 \%$ \\
\hline 44 & NB_Grade_43 & 3 & 498.36 & $7.31 \%$ \\
\hline 45 & BB_Grade_44 & 3 & 498.36 & $5.41 \%$ \\
\hline 46 & NB_Grade_45 & 3 & 423.36 & $-0.55 \%$ \\
\hline 47 & NB_Grade_46 & 3 & 498.36 & $-6.95 \%$ \\
\hline 48 & NB_Grade_47(1) & 3 & 295.628 & $-7.15 \%$ \\
\hline 49 & NB_Grade_47(2) & 2 & 98.36 & $-7.15 \%$ \\
\hline 50 & NB_Grade_48 & 2 & 498.36 & $-7.08 \%$ \\
\hline 51 & NB_Grade_49 & 2 & 498.36 & $-5.89 \%$ \\
\hline 52 & NB_Grade_50 & 2 & 498.36 & $-9.78 \%$ \\
\hline 53 & NB_Grade_51 & 2 & 498.36 & $-2.86 \%$ \\
\hline 54 & NB_Grade_52 & 2 & 498.36 & $-2.25 \%$ \\
\hline 55 & NB_Grade_53 & 2 & 498.36 & $-4.42 \%$ \\
\hline 56 & NB_Grade_54 & 2 & 498.36 & $-3.19 \%$ \\
\hline 57 & NB_Grade_55 & 2 & 498.36 & $-2.20 \%$ \\
\hline 58 & NB_Grade_56 & 2 & 498.36 & $-2.37 \%$ \\
\hline 59 & NB_Grade_57 & 2 & 498.36 & $-2.10 \%$ \\
\hline 60 & NB_Grade_58 & 2 & 498.36 & $-2.45 \%$ \\
\hline 61 & NB_Grade_59 & 2 & 498.36 & $-2.43 \%$ \\
\hline 62 & NB_Grade_60 & 2 & 498.36 & $-2.40 \%$ \\
\hline 63 & NB_Grade_61 & 2 & 498.36 & $-4.42 \%$ \\
\hline 64 & NB_Grade_62 & 2 & 498.36 & $-3.10 \%$ \\
\hline 65 & NB_Grade_63 & 2 & 498.36 & $-1.34 \%$ \\
\hline 66 & NB_Grade_64 & 2 & 498.36 & $-0.21 \%$ \\
\hline 67 & NB_Grade_65 & 2 & 495.59 & $0.84 \%$ \\
\hline 68 & NB_Grade_66 & 2 & 493.388 & $-2.19 \%$ \\
\hline 69 & NB_Grade_67 & 2 & 497.608 & $-4.89 \%$ \\
\hline 70 & NB_Grade_68 & 2 & 498.359 & $-5.05 \%$ \\
\hline 71 & NB_Grade_69 & 2 & 498.36 & $-3.71 \%$ \\
\hline 72 & NB_Grade_70 & 2 & 498.36 & $-0.93 \%$ \\
\hline & & & \\
\hline
\end{tabular}




\begin{tabular}{|r|l|r|r|r|}
\hline 73 & NB_Grade_71 & 2 & 498.36 & $-0.92 \%$ \\
\hline 74 & NB_Grade_72 & 2 & 498.36 & $-0.28 \%$ \\
\hline 75 & NB_Grade_73 & 2 & 498.36 & $0.16 \%$ \\
\hline 76 & SB_Grade_1 & 2 & 498.36 & $0.92 \%$ \\
\hline 77 & SB_Grade_2(1) & 2 & 122.953 & $0.93 \%$ \\
\hline 78 & SB_Grade_2(2) & 2 & 401.174 & $0.93 \%$ \\
\hline 79 & SB_Grade_3 & 2 & 456.407 & $3.71 \%$ \\
\hline 80 & SB_Grade_4 & 2 & 501.107 & $5.05 \%$ \\
\hline 81 & SB_Grade_5 & 2 & 498.36 & $4.89 \%$ \\
\hline 82 & SB_Grade_6 & 2 & 498.36 & $2.19 \%$ \\
\hline 83 & SB_Grade_7 & 2 & 498.36 & $-0.84 \%$ \\
\hline 84 & SB_Grade_8 & 2 & 498.36 & $0.21 \%$ \\
\hline 85 & SB_Grade_9 & 2 & 539.866 & $1.34 \%$ \\
\hline 86 & SB_Grade_10 & 2 & 530.123 & $3.10 \%$ \\
\hline 87 & SB_Grade_11 & 2 & 2 \\
\hline 88 & SB_Grade_12 & 2 & 508.814 & $4.42 \%$ \\
\hline 89 & SB_Grade_13 & 2 & 511.314 & $2.40 \%$ \\
\hline 90 & SB_Grade_14 & 2 & 502.248 & $2.43 \%$ \\
\hline 91 & SB_Grade_15 & 2 & 450.144 & $2.45 \%$ \\
\hline 92 & SB_Grade_16 & 2 & 452.962 & $2.10 \%$ \\
\hline 93 & SB_Grade_17 & 2 & 482.509 & $2.37 \%$ \\
\hline 94 & SB_Grade_18 & 2 & 523.244 & $2.20 \%$ \\
\hline 95 & SB_Grade_19 & 2 & 496.497 & $3.19 \%$ \\
\hline 96 & SB_Grade_20 & 2 & 500.993 & $4.42 \%$ \\
\hline 97 & SB_Grade_21 & 2 & 491.838 & $2.25 \%$ \\
\hline 98 & SB_Grade_22 & 2 & 504.156 & $2.86 \%$ \\
\hline 99 & SB_Grade_23 & 2 & 523.414 & $9.78 \%$ \\
\hline 100 & SB_Grade_24(1) & 2 & 488.557 & $5.89 \%$ \\
\hline 101 & SB_Grade_24(2) & 2 & 109.545 & $7.08 \%$ \\
\hline 102 & SB_Grade_25 & 3 & 297.371 & $7.08 \%$ \\
\hline 103 & SB_Grade_26 & 3 & 505.487 & $7.15 \%$ \\
\hline 104 & SB_Grade_27 & 3 & 513.171 & $6.95 \%$ \\
\hline & & 3 & 423.36 & $0.55 \%$ \\
\hline
\end{tabular}




\begin{tabular}{|r|l|r|r|r|}
\hline 105 & SB_Grade_28 & 3 & 464.902 & $-5.41 \%$ \\
\hline 106 & SB_Grade_29 & 3 & 498.36 & $-7.31 \%$ \\
\hline 107 & SB_Grade_30 & 3 & 498.36 & $-6.28 \%$ \\
\hline 108 & SB_Grade_31 & 3 & 498.36 & $-6.05 \%$ \\
\hline 109 & SB_Grade_32 & 3 & 494.305 & $-6.98 \%$ \\
\hline 110 & SB_Grade_33 & 3 & 487.612 & $-7.68 \%$ \\
\hline 111 & SB_Grade_34 & 3 & 931.211 & $-6.64 \%$ \\
\hline 112 & SB_Grade_35 & 3 & 1260.492 & $-7.12 \%$ \\
\hline 113 & SB_Grade_36 & 3 & 536.421 & $-7.40 \%$ \\
\hline 114 & SB_Grade_37 & 3 & 1167.002 & $-6.96 \%$ \\
\hline 115 & SB_Grade_38 & 3 & 1815.663 & $-6.96 \%$ \\
\hline 116 & SB_Grade_39 & 3 & 894.183 & $-7.40 \%$ \\
\hline 117 & SB_Grade_40 & 3 & 418.989 & $-6.85 \%$ \\
\hline 118 & SB_Grade_41 & 3 & 606.307 & $-7.56 \%$ \\
\hline 119 & SB_Grade_42 & 3 & 486.983 & $-7.12 \%$ \\
\hline 120 & SB_Grade_43 & 3 & 448.172 & $-7.48 \%$ \\
\hline 121 & SB_Grade_44 & 3 & 125.714 & $-7.00 \%$ \\
\hline 122 & SB_Grade_45 & 3 & 27.47 & $-7.16 \%$ \\
\hline 123 & SB_Grade_46 & 3 & 191.735 & $-7.16 \%$ \\
\hline 124 & SB_Grade_47 & 3 & 584.658 & $-7.36 \%$ \\
\hline 125 & SB_Grade_48 & 3 & 192.123 & $-7.08 \%$ \\
\hline 126 & SB_Grade_49 & 3 & 140.844 & $-6.11 \%$ \\
\hline 127 & SB_Grade_50 & 3 & 123.593 & $-5.00 \%$ \\
\hline 128 & SB_Grade_51 & 3 & 350.683 & $-4.12 \%$ \\
\hline 129 & SB_Grade_52 & 3 & 270.943 & $-2.52 \%$ \\
\hline 130 & SB_Grade_53(1) & 3 & 105.456 & $-2.88 \%$ \\
\hline 131 & SB_Grade_53(2) & 2 & 164.539 & $-2.88 \%$ \\
\hline 132 & SB_Grade_54 & 2 & 350.498 & $-2.52 \%$ \\
\hline 133 & SB_Grade_55 & 2 & 425.228 & $-2.60 \%$ \\
\hline 134 & SB_Grade_56 & 2 & 276.624 & $-1.40 \%$ \\
\hline 135 & SB_Grade_57 & 2 & 1090.194 & $-1.40 \%$ \\
\hline 136 & SB_Grade_58 & 2 & 450.126 & $-2.38 \%$ \\
\hline & & &
\end{tabular}




\begin{tabular}{|r|l|r|r|r|}
\hline 137 & SB_Grade_59 & 2 & 203.425 & $-3.36 \%$ \\
\hline 138 & SB_Grade_60 & 2 & 551.494 & $-2.43 \%$ \\
\hline 139 & SB_Grade_61 & 2 & 250.773 & $-1.88 \%$ \\
\hline 140 & SB_Grade_62 & 2 & 167.606 & $-1.56 \%$ \\
\hline 141 & SB_Grade_63 & 2 & 229.121 & $-1.84 \%$ \\
\hline 142 & SB_Grade_64 & 2 & 1032.703 & $-1.84 \%$ \\
\hline 143 & SB_Grade_65 & 2 & 193.239 & $-1.08 \%$ \\
\hline 144 & SB_Grade_66 & 2 & 340.247 & $-2.48 \%$ \\
\hline 145 & SB_Grade_67 & 2 & 191.698 & $-4.16 \%$ \\
\hline 146 & SB_Grade_68 & 2 & 246.491 & $-3.66 \%$ \\
\hline 147 & SB_Grade_69 & 2 & 250.39 & $-3.68 \%$ \\
\hline 148 & SB_Grade_70 & 2 & 243.275 & $-0.20 \%$ \\
\hline 149 & SB_Grade_71 & 2 & 220.99 & $-1.00 \%$ \\
\hline 150 & SB_101_Flat & 2 & 5911.95 & $0.00 \%$ \\
\hline 151 & NB_101_Flat_1 & 2 & 348.129 & $0.00 \%$ \\
\hline 152 & NB_101_Flat_2 & 2 & 465.526 & $0.00 \%$ \\
\hline 153 & NB_101_Flat_3 & 2 & 5104.263 & $0.00 \%$ \\
\hline 154 & Reservoir_Canyon_Rd_NB_On & 1 & 67.789 & $0.00 \%$ \\
\hline 155 & Vista_Del_Ciudad_NB_Off & 1 & 56.986 & $0.00 \%$ \\
\hline 156 & Vista_Del_Ciudad_NB_On & 1 & 59.974 & $0.00 \%$ \\
\hline 157 & Vista_Del_Ciudad_SB_On & 1 & 489.316 & $0.00 \%$ \\
\hline 158 & Cuesta_Springs_Rd_NB_Off & 1 & 49.051 & $0.00 \%$ \\
\hline 159 & Cuesta_Springs_Rd_NB_On & 1 & 38.429 & $0.00 \%$ \\
\hline 160 & Tassajara_Creek_Rd_NB_Off(1) & 1 & 310.382 & $0.00 \%$ \\
\hline 161 & Tassajara_Creek_Rd_NB_Off(2) & 1 & 119.615 & $0.00 \%$ \\
\hline 162 & Tassajara_Creek_Rd_NB_Off(3) & 1 & 43.683 & $0.00 \%$ \\
\hline 163 & Tassajara_Creek_Rd_NB_On & 1 & 52.701 & $0.00 \%$ \\
\hline 164 & Tassajara_Creek_Rd_SB_Off & 1 & 45.415 & $0.00 \%$ \\
\hline 165 & Tassajara_Creek_Rd_SB_Off & 1 & 60.83 & $0.00 \%$ \\
\hline 166 & Tassajara_Creek_SB_On & 1 & 21.189 & $0.00 \%$ \\
\hline 167 & Cuesta_Springs_Rd_SB_Off & 1 & 100.978 & $0.00 \%$ \\
\hline 168 & Cuesta_Springs_Rd_SB_On & 117.373 & $0.00 \%$ \\
\hline
\end{tabular}




\begin{tabular}{|r|l|r|r|r|}
\hline 169 & TV_Tower_Rd_Off_Lane & 1 & 1051.465 & $0.00 \%$ \\
\hline 170 & TV_Road_SB_Off & 1 & 60.192 & $0.00 \%$ \\
\hline 171 & TV_Road_SB_On & 1 & 54.704 & $0.00 \%$ \\
\hline 172 & Old_101_SB_Off & 1 & 151.798 & $0.00 \%$ \\
\hline 173 & Old_Stage_Coach_Rd_SB_Off & 1 & 501.558 & $0.00 \%$ \\
\hline 174 & Old_Stage_Coach_Rd_SB_On & 1 & 546.597 & $0.00 \%$ \\
\hline 175 & Old_Stage_Coach_Rd_NB_On & 1 & 29.019 & $0.00 \%$ \\
\hline 176 & Old_Stage_Coach_Rd_NB_On_Lane & 1 & 581.311 & $0.00 \%$ \\
\hline 177 & Hawk_Hill_Rd_SB_Off & 1 & 126.483 & $0.00 \%$ \\
\hline 178 & Miossi_Rd_SB_Off & 1 & 479.619 & $0.00 \%$ \\
\hline 179 & Hawk_Hill_Rd_SB_On & 1 & 42.094 & $0.00 \%$ \\
\hline 180 & Reservoir_Canyon_Rd_SB_Off_Lane & 1 & 264.397 & $-1.00 \%$ \\
\hline 181 & Vista_Del_Ciudad_SB_Off_Lane & 1 & 619.878 & $0.00 \%$ \\
\hline 183 & TV_Tower_Rd_Off_Lane & 1 & 473.414 & $0.00 \%$ \\
\hline 202 & NB_101_Flat_3_Connector & 2 & 3.286 & $0.00 \%$ \\
\hline 203 & NB_Grade_1_Connector & 2 & 3.286 & $1.00 \%$ \\
\hline 204 & NB_Grade_2_Connector & 2 & 3.286 & $0.20 \%$ \\
\hline 205 & NB_Grade_3_Connector & 2 & 3.286 & $3.68 \%$ \\
\hline 206 & NB_Grade_4_Connector & 2 & 3.286 & $3.66 \%$ \\
\hline 207 & NB_Grade_5_Connector & 2 & 3.286 & $4.16 \%$ \\
\hline 208 & NB_Grade_6_Connector & 2 & 3.286 & $2.48 \%$ \\
\hline 209 & NB_Grade_7_Connector & 2 & 3.286 & $1.08 \%$ \\
\hline 210 & NB_Grade_8_Connector & 2 & 3.286 & $1.84 \%$ \\
\hline 211 & NB_Grade_9_Connector & 2 & 3.286 & $1.84 \%$ \\
\hline 212 & NB_Grade_10_Connector & 2 & 3.286 & $1.56 \%$ \\
\hline 213 & NB_Grade_11_Connector & 2 & 3.286 & $1.88 \%$ \\
\hline 214 & NB_Grade_12_Connector & 2 & 3.286 & $2.43 \%$ \\
\hline 215 & NB_Grade_13_Connector & 2 & 3.286 & $3.36 \%$ \\
\hline 216 & NB_Grade_14_Connector & 2 & 3.286 & $2.38 \%$ \\
\hline 217 & NB_Grade_15_Connector & 2 & 3.286 & $1.40 \%$ \\
\hline 218 & NB_Grade_16_Connector & 2 & 3.286 & $1.40 \%$ \\
\hline 219 & NB_Grade_17_Connector & 3.286 & $2.60 \%$ \\
\hline & & 2 & &
\end{tabular}




\begin{tabular}{|c|c|c|c|c|}
\hline 220 & NB_Grade_18_Connector & 2 & 3.286 & $2.52 \%$ \\
\hline 221 & NB_Grade_19_Connector & 2 & 3.286 & $2.88 \%$ \\
\hline 222 & NB_Grade_20_Connector & 2 & 3.286 & $2.52 \%$ \\
\hline 223 & NB_Grade_21_Connector(1) & 2 & 30.389 & $4.12 \%$ \\
\hline 224 & NB_Grade_21_Connector(2) & 3 & 3.286 & $4.12 \%$ \\
\hline 225 & NB_Grade_22_Connector & 3 & 3.286 & $5.00 \%$ \\
\hline 226 & NB_Grade_23_Connector & 3 & 3.286 & $6.11 \%$ \\
\hline 227 & NB_Grade_24_Connector & 3 & 3.286 & $7.08 \%$ \\
\hline 228 & NB_Grade_25_Connector & 3 & 3.286 & $7.36 \%$ \\
\hline 229 & NB_Grade_26_Connector & 3 & 3.286 & $7.16 \%$ \\
\hline 230 & NB_Grade_27_Connector & 3 & 3.286 & $7.16 \%$ \\
\hline 231 & NB_Grade_28_Connector & 3 & 3.286 & $7.00 \%$ \\
\hline 232 & NB_Grade_29_Connector & 3 & 3.286 & $7.48 \%$ \\
\hline 233 & NB_Grade_30_Connector & 3 & 3.286 & $7.12 \%$ \\
\hline 234 & NB_Grade_31_Connector & 3 & 3.286 & $7.56 \%$ \\
\hline 235 & NB_Grade_32_Connector & 3 & 3.286 & $6.85 \%$ \\
\hline 236 & NB_Grade_33_Connector & 3 & 3.286 & $7.40 \%$ \\
\hline 237 & NB_Grade_34_Connector & 3 & 3.286 & $6.96 \%$ \\
\hline 238 & NB_Grade_35_Connector & 3 & 3.286 & $6.96 \%$ \\
\hline 239 & NB_Grade_36_Connector & 3 & 3.286 & $7.40 \%$ \\
\hline 240 & NB_Grade_37_Connector & 3 & 3.286 & $7.12 \%$ \\
\hline 241 & NB_Grade_38_Connector & 3 & 3.286 & $6.64 \%$ \\
\hline 242 & NB_Grade_39_Connector & 3 & 3.286 & $7.40 \%$ \\
\hline 243 & NB_Grade_40_Connector & 3 & 3.286 & $8.40 \%$ \\
\hline 244 & NB_Grade_41_Connector & 3 & 3.286 & $6.30 \%$ \\
\hline 245 & NB_Grade_42_Connector & 3 & 3.286 & $6.70 \%$ \\
\hline 246 & NB_Grade_43_Connector & 3 & 3.286 & $6.60 \%$ \\
\hline 247 & NB_Grade_44_Connector & 3 & 3.286 & $6.30 \%$ \\
\hline 248 & NB_Grade_45_Connector & 3 & 3.286 & $3.10 \%$ \\
\hline 249 & NB_Grade_46_Connector & 3 & 3.283 & $-6.20 \%$ \\
\hline 250 & NB_Grade_47_Connector(1) & 2 & 109.261 & $-6.80 \%$ \\
\hline 251 & NB_Grade_47_Connector(2) & 2 & 3.286 & $-6.80 \%$ \\
\hline
\end{tabular}




\begin{tabular}{|r|l|r|r|r|}
\hline 252 & NB_Grade_48_Connector & 2 & 3.286 & $-7.10 \%$ \\
\hline 253 & NB_Grade_49_Connector & 2 & 3.286 & $-6.80 \%$ \\
\hline 254 & NB_Grade_50_Connector & 2 & 3.286 & $-10.20 \%$ \\
\hline 255 & NB_Grade_51_Connector & 2 & 3.286 & $-5.60 \%$ \\
\hline 256 & NB_Grade_52_Connector & 2 & 3.286 & $-1.80 \%$ \\
\hline 257 & NB_Grade_53_Connector & 2 & 3.286 & $-7.10 \%$ \\
\hline 258 & NB_Grade_54_Connector & 2 & 3.286 & $-4.60 \%$ \\
\hline 259 & NB_Grade_55_Connector & 2 & 3.286 & $-3.90 \%$ \\
\hline 260 & NB_Grade_56_Connector & 2 & 3.286 & $-2.50 \%$ \\
\hline 261 & NB_Grade_57_Connector & 2 & 3.286 & $-4.90 \%$ \\
\hline 262 & NB_Grade_58_Connector & 2 & 3.286 & $-3.20 \%$ \\
\hline 263 & NB_Grade_59_Connector & 2 & 3.286 & $-2.10 \%$ \\
\hline 264 & NB_Grade_60_Connector & 2 & 3.286 & $-3.30 \%$ \\
\hline 265 & NB_Grade_61_Connector & 2 & 3.286 & $-6.50 \%$ \\
\hline 266 & NB_Grade_62_Connector & 2 & 3.286 & $-3.10 \%$ \\
\hline 267 & NB_Grade_63_Connector & 2 & 3.286 & $-3.60 \%$ \\
\hline 268 & NB_Grade_64_Connector & 2 & 3.434 & $-2.80 \%$ \\
\hline 269 & NB_Grade_65_Connector & 2 & 6.471 & $-2.20 \%$ \\
\hline 270 & NB_Grade_66_Connector & 2 & 9.286 & $-3.50 \%$ \\
\hline 271 & NB_Grade_67_Connector & 2 & 3.286 & $-5.50 \%$ \\
\hline 272 & NB_Grade_68_Connector & 2 & 3.286 & $-4.20 \%$ \\
\hline 273 & NB_Grade_69_Connector & 2 & 3.286 & $-2.80 \%$ \\
\hline 274 & NB_Grade_70_Connector & 2 & 3.286 & $-1.20 \%$ \\
\hline 275 & NB_Grade_71_Connector & 2 & 3.286 & $-2.20 \%$ \\
\hline 276 & NB_Grade_72_Connector & 2 & 3.286 & $-1.40 \%$ \\
\hline 277 & SB_Grade_1_Connector & 2 & 3.286 & $2.20 \%$ \\
\hline 280 & SB_Grade_3_Connector & 2 & 3.286 & $2.80 \%$ \\
\hline 281 & SB_Grade_4_Connector & 2 & 3.762 & $4.20 \%$ \\
\hline 282 & SB_Grade_5_Connector & 2 & 3.286 & $5.50 \%$ \\
\hline 283 & SB_Grade_6_Connector & 2 & 3.286 & $3.50 \%$ \\
\hline 284 & SB_Grade_7_Connector & 2 & 3.286 & $2.20 \%$ \\
\hline 285 & SB_Grade_8_Connector & $2.80 \%$ \\
\hline & & 286 & \\
\hline
\end{tabular}




\begin{tabular}{|r|l|r|r|r|}
\hline 286 & SB_Grade_9_Connector & 2 & 12.558 & $3.60 \%$ \\
\hline 287 & SB_Grade_10_Connector & 2 & 29.703 & $3.10 \%$ \\
\hline 288 & SB_Grade_11_Connector & 2 & 16.408 & $6.50 \%$ \\
\hline 289 & SB_Grade_12_Connector & 2 & 16.118 & $3.30 \%$ \\
\hline 290 & SB_Grade_13_Connector & 2 & 3.286 & $2.10 \%$ \\
\hline 291 & SB_Grade_14_Connector & 2 & 16.203 & $3.20 \%$ \\
\hline 292 & SB_Grade_15_Connector & 2 & 14.834 & $4.90 \%$ \\
\hline 293 & SB_Grade_16_Connector & 2 & 3.286 & $2.50 \%$ \\
\hline 294 & SB_Grade_17_Connector & 2 & 7.328 & $3.90 \%$ \\
\hline 295 & SB_Grade_18_Connector & 2 & 13.301 & $4.60 \%$ \\
\hline 296 & SB_Grade_19_Connector & 2 & 2.419 & $7.10 \%$ \\
\hline 297 & SB_Grade_20_Connector & 2 & 3.286 & $1.80 \%$ \\
\hline 298 & SB_Grade_21_Connector & 2 & 13.437 & $5.60 \%$ \\
\hline 299 & SB_Grade_22_Connector & 2 & 12.16 & $10.20 \%$ \\
\hline 300 & SB_Grade_23_Connector & 2 & 1.902 & $6.80 \%$ \\
\hline 301 & SB_Grade_24_Connector(1) & 2 & 96.047 & $7.10 \%$ \\
\hline 302 & SB_Grade_24_Connector(2) & 3 & 3.286 & $7.10 \%$ \\
\hline 303 & SB_Grade_25_Connector & 3 & 3.286 & $6.80 \%$ \\
\hline 304 & SB_Grade_26_Connector & 3 & 3.286 & $6.20 \%$ \\
\hline 305 & SB_Grade_27_Connector & 3 & 3.286 & $-3.10 \%$ \\
\hline 306 & SB_Grade_28_Connector & 3 & 3.286 & $-6.30 \%$ \\
\hline 307 & SB_Grade_29_Connector & 3 & 3.286 & $-6.60 \%$ \\
\hline 308 & SB_Grade_30_Connector & 3 & 3.286 & $-6.70 \%$ \\
\hline 309 & SB_Grade_31_Connector & 3 & 3.286 & $-6.30 \%$ \\
\hline 310 & SB_Grade_32_Connector & 3 & 3.286 & $-8.40 \%$ \\
\hline 311 & SB_Grade_33_Connector & 3 & 3.286 & $-7.40 \%$ \\
\hline 312 & SB_Grade_34_Connector & 3 & 3.286 & $-6.64 \%$ \\
\hline 313 & SB_Grade_35_Connector & 3 & 3.286 & $-7.12 \%$ \\
\hline 314 & SB_Grade_36_Connector & 3 & 3.286 & $-7.40 \%$ \\
\hline 315 & SB_Grade_37_Connector & 3 & 3.286 & $-6.96 \%$ \\
\hline 316 & SB_Grade_38_Connector & 3.286 & $-6.96 \%$ \\
\hline 317 & SB_Grade_39_Connector & 3.286 & $-7.40 \%$ \\
\hline & & &
\end{tabular}




\begin{tabular}{|r|l|r|r|r|}
\hline 318 & SB_Grade_40_Connector & 3 & 3.286 & $-6.85 \%$ \\
\hline 319 & SB_Grade_41_Connector & 3 & 3.281 & $-7.56 \%$ \\
\hline 320 & SB_Grade_42_Connector & 3 & 3.285 & $-7.12 \%$ \\
\hline 321 & SB_Grade_43_Connector & 3 & 3.286 & $-7.48 \%$ \\
\hline 322 & SB_Grade_44_Connector & 3 & 8.029 & $-7.00 \%$ \\
\hline 323 & SB_Grade_45_Connector & 3 & 5.288 & $-7.16 \%$ \\
\hline 324 & SB_Grade_46_Connector & 3 & 3.285 & $-7.16 \%$ \\
\hline 325 & SB_Grade_47_Connector & 3 & 3.286 & $-7.36 \%$ \\
\hline 326 & SB_Grade_48_Connector & 3 & 3.286 & $-7.08 \%$ \\
\hline 327 & SB_Grade_49_Connector & 3 & 3.286 & $-6.11 \%$ \\
\hline 328 & SB_Grade_50_Connector & 3 & 3.286 & $-5.00 \%$ \\
\hline 329 & SB_Grade_51_Connector & 3 & 3.286 & $-4.12 \%$ \\
\hline 330 & SB_Grade_52_Connector & 3 & 3.286 & $-2.52 \%$ \\
\hline 331 & SB_Grade_53_Connector(1) & 2 & 22.235 & $-2.88 \%$ \\
\hline 332 & SB_Grade_53_Connector(2) & 2 & 3.286 & $-2.88 \%$ \\
\hline 333 & SB_Grade_54_Connector & 2 & 3.286 & $-2.52 \%$ \\
\hline 334 & SB_Grade_55_Connector & 2 & 3.286 & $-2.60 \%$ \\
\hline 335 & SB_Grade_56_Connector & 2 & 3.286 & $-1.40 \%$ \\
\hline 336 & SB_Grade_57_Connector & 2 & 3.286 & $-1.40 \%$ \\
\hline 337 & SB_Grade_58_Connector & 2 & 3.286 & $-2.38 \%$ \\
\hline 338 & SB_Grade_59_Connector & 2 & 3.286 & $-3.36 \%$ \\
\hline 339 & SB_Grade_60_Connector & 2 & 3.286 & $-2.43 \%$ \\
\hline 340 & SB_Grade_61_Connector & 2 & 3.286 & $-1.88 \%$ \\
\hline 341 & SB_Grade_62_Connector & 2 & 3.286 & $-1.56 \%$ \\
\hline 342 & SB_Grade_63_Connector & 2 & 3.286 & $-1.84 \%$ \\
\hline 343 & SB_Grade_64_Connector & 2 & 3.286 & $-1.84 \%$ \\
\hline 344 & SB_Grade_65_Connector & 2 & 3.285 & $-1.08 \%$ \\
\hline 345 & SB_Grade_66_Connector & 2 & 3.286 & $-2.48 \%$ \\
\hline 346 & SB_Grade_67_Connector & 2 & 3.286 & $-4.16 \%$ \\
\hline 347 & SB_Grade_68_Connector & 2 & 3.286 & $-3.66 \%$ \\
\hline 348 & SB_Grade_69_Connector & 2 & 3.286 & $-3.68 \%$ \\
\hline 349 & SB_Grade_70_Connector & 3.286 & $-0.20 \%$ \\
\hline & & & \\
\hline
\end{tabular}




\begin{tabular}{|c|c|c|c|c|}
\hline 350 & SB_Grade_71_Connector & 2 & 3.286 & $-1.00 \%$ \\
\hline 400 & Fox_Hollow_Rd_NB_On & 1 & 94.88 & $0.00 \%$ \\
\hline 401 & Fox_Hollow_Rd_NB_Off & 1 & 41.673 & $0.00 \%$ \\
\hline 402 & Reservoir_Canyon_Rd_NB_Off(1) & 1 & 292.74 & $0.00 \%$ \\
\hline 404 & Reservoir_Canyon_Rd_NB_Off(2) & 1 & 25.195 & $0.00 \%$ \\
\hline 500 & Monterey_NB_On-Ramp & 1 & 321.25 & $0.00 \%$ \\
\hline 501 & JCT58_NB_Off-Ramp & 1 & 440.618 & $0.00 \%$ \\
\hline 502 & JCT58_SB_On-Ramp & 1 & 502.895 & $0.00 \%$ \\
\hline 503 & Monterey_SB_Off-Ramp & 1 & 402.61 & $0.00 \%$ \\
\hline 600 & Monterey_NB_On-Ramp_Connector & 1 & 452.845 & $0.00 \%$ \\
\hline 601 & JCT58_NB_Off-Ramp_Connector & 1 & 161.922 & $0.00 \%$ \\
\hline 602 & JCT58_SB_On-Ramp_Connector & 1 & 398.268 & $0.00 \%$ \\
\hline 603 & Monterey_SB_Off-Ramp_Connector & 1 & 103.754 & $0.00 \%$ \\
\hline 10000 & Fox_Hollow_Rd_NB_Connector & 1 & 23.988 & $0.00 \%$ \\
\hline 10001 & Fox_Hollow_Rd_NB_Off_Connector & 1 & 89.066 & $0.00 \%$ \\
\hline 10002 & Reservoir_Canyon_Rd_NB_Off_Connector(2) & 1 & 76.353 & $0.00 \%$ \\
\hline 10003 & Reservoir_Canyon_Rd_NB_Off_Connector(1) & 1 & 71.481 & $0.00 \%$ \\
\hline 10004 & Reservoir_Canyon_Rd_NB_On_Connector & 1 & 50.33 & $1.00 \%$ \\
\hline 10005 & Vista_Del_Ciudad_NB_Off_Connector & 1 & 55.823 & $0.00 \%$ \\
\hline 10006 & Vista_Del_Ciudad_NB_On_Connector_RT & 1 & 50.633 & $7.40 \%$ \\
\hline 10007 & Vista_Del_Ciudad_SB_On_Connector & 1 & 114.741 & $0.00 \%$ \\
\hline 10008 & Vista_Del_Ciudad_SB_On_Connector & 1 & 38.291 & $-6.85 \%$ \\
\hline 10009 & Reservoir_Canyon_Rd_SB_On & 1 & 95.431 & $0.00 \%$ \\
\hline 10010 & Cuesta_Springs_Rd_NB_Off_Connector & 1 & 25.465 & $0.00 \%$ \\
\hline 10011 & Cuesta_Springs_Rd_NB_On_Connector & 1 & 31.091 & $-6.20 \%$ \\
\hline 10012 & Tassajara_Creek_Rd_NB_Off_Connector(1) & 1 & 72.956 & $0.00 \%$ \\
\hline 10013 & Tassajara_Creek_Rd_NB_Off_Connector(2) & 1 & 46.644 & $0.00 \%$ \\
\hline 10014 & Tassajara_Creek_Rd_NB_Off_Connector & 1 & 35.716 & $0.00 \%$ \\
\hline 10015 & Tassajara_Creek_Rd_NB_On_Connector & 1 & 31.868 & $-3.10 \%$ \\
\hline 10016 & Tassjara_Creek_Connector(1) & 1 & 76.65 & $0.00 \%$ \\
\hline 10017 & Tassjara_Creek_Connector(2) & 1 & 75.011 & $0.00 \%$ \\
\hline 10018 & Tassjara_Creek_Connector(3) & 1 & 45.061 & $0.00 \%$ \\
\hline
\end{tabular}




\begin{tabular}{|r|l|r|r|r|}
\hline 10019 & Tassjara_Creek_Connector(4) & 1 & 37.731 & $0.00 \%$ \\
\hline 10020 & Tassjara_Creek_Connector(5) & 1 & 61.665 & $0.00 \%$ \\
\hline 10021 & Tassjara_Creek_Connector(6) & 1 & 29.622 & $3.10 \%$ \\
\hline 10022 & Tassjara_Creek_Connector(7) & 1 & 70.505 & $-3.10 \%$ \\
\hline 10023 & Tassajara_Creek_Rd_SB_Off & 1 & 38.748 & $0.00 \%$ \\
\hline 10024 & Cuesta_Springs_Rd_SB_Off_Connector & 1 & 24.325 & $0.00 \%$ \\
\hline 10025 & Cuesta_Springs_SB_On_Connector & 1 & 50.625 & $6.20 \%$ \\
\hline 10026 & TV_Tower_Rd_Off_Lane_Connector & 1 & 104.016 & $0.00 \%$ \\
\hline 10027 & TV_Road_On_Lane_Connector & 1 & 53.322 & $-6.70 \%$ \\
\hline 10028 & TV_Road_SB_Off_Connector & 1 & 37.698 & $0.00 \%$ \\
\hline 10029 & TV_Road_SB_On_Connector & 1 & 24.381 & $0.00 \%$ \\
\hline 10030 & Old_101_SB_Off_Connector & 1 & 43.904 & $0.00 \%$ \\
\hline 10031 & Old_Stage_Coach_Rd_SB_Off_Connector & 1 & 30.026 & $0.00 \%$ \\
\hline 10032 & Old_Stage_Coach_Rd_SB_On_Connector & 1 & 62.396 & $-6.11 \%$ \\
\hline 10033 & Old_Stage_Coach_Rd_NB_On_Connector & 1 & 58.986 & $7.00 \%$ \\
\hline 10034 & Old_Stage_Coach_Rd_NB_On_Connector & 1 & 97.244 & $0.00 \%$ \\
\hline 10035 & Hawk_Hill_Rd_SB_Off_Connector & 1 & 34.244 & $0.00 \%$ \\
\hline 10036 & Hawk_Hill_Rd_SB_Off_Connector & 1 & 34.502 & $0.00 \%$ \\
\hline 10037 & Hawk_Hill_Rd_SB_On_Connector & 1 & 43.062 & $0.00 \%$ \\
\hline 10038 & Cuesta_Springs_Rd_SB_Off_Connector & 1 & 55.749 & $0.00 \%$ \\
\hline 10039 & Tassajara_Rd_SB_On_Connector & 1 & 31.252 & $3.10 \%$ \\
\hline 10040 & Reservoir_Canyon_Rd_SB_Off_Connector & 1 & 119.146 & $0.00 \%$ \\
\hline 10041 & Reservoir_Canyon_Rd_SB_Off_Lane_Connector & 1 & 54.214 & $-0.20 \%$ \\
\hline 10042 & Vista_Del_Ciudad_SB_Off_Lane_Connector & 1 & 68.186 & $0.00 \%$ \\
\hline 10043 & Vista_Del_Ciudad_SB_Off_Connector & 1 & 120.604 & $0.00 \%$ \\
\hline 10044 & SB_Grade_1_Connector & 2 & 23.308 & $1.20 \%$ \\
\hline 10045 & SB_Grade_2_Connector & 2 & 5.431 & $2.80 \%$ \\
\hline 10046 & NB_101_Flat_2_Connector & 2 & 12.53 & $0.00 \%$ \\
\hline 10047 & NB_101_Flat_1_Connector & 2 & 16.146 & $0.00 \%$ \\
\hline & & &
\end{tabular}


APPENDIX B: ORIGIN-DESTINATION MATRICES

\begin{tabular}{|c|c|c|c|c|c|c|c|c|c|c|c|}
\hline $\begin{array}{c}\text { NORTHBOUND } \\
\text { Network } 1\end{array}$ & $\begin{array}{l}\text { US } \\
101 \\
\text { Start }\end{array}$ & Monterey & $\begin{array}{l}\text { Fox } \\
\text { Hollow }\end{array}$ & $\begin{array}{l}\text { Reservoir } \\
\text { Canyon }\end{array}$ & $\begin{array}{l}\text { Vista } \\
\text { Del } \\
\text { Ciudad }\end{array}$ & $\begin{array}{l}\text { Cuesta } \\
\text { Springs }\end{array}$ & $\begin{array}{l}\text { Tassajara } \\
\text { Creek East }\end{array}$ & $\begin{array}{l}\text { Tassajara } \\
\text { Creek } \\
\text { West }\end{array}$ & $\begin{array}{l}\text { Junction } \\
58 \text { East }\end{array}$ & $\begin{array}{l}\text { US } \\
101 \\
\text { North }\end{array}$ & $\begin{array}{l}\text { US } \\
101 \\
\text { South }\end{array}$ \\
\hline US 101 Start & 0 & 0 & 50 & 50 & 50 & 50 & 50 & 50 & 150 & 2,170 & 0 \\
\hline Monterey & 0 & 0 & 5 & 5 & 5 & 5 & 5 & 5 & 50 & 245 & 0 \\
\hline Fox Hollow & 0 & 0 & 0 & 0 & 0 & 0 & 0 & 0 & 0 & 5 & 0 \\
\hline $\begin{array}{l}\text { Reservoir } \\
\text { Canyon }\end{array}$ & 0 & 0 & 0 & 0 & 0 & 0 & 0 & 0 & 0 & 5 & 0 \\
\hline Vista Del Ciudad & 0 & 0 & 0 & 0 & 0 & 0 & 0 & 0 & 0 & 5 & 0 \\
\hline Cuesta Springs & 0 & 0 & 0 & 0 & 0 & 0 & 0 & 0 & 0 & 5 & 0 \\
\hline $\begin{array}{l}\text { Tassajara Creek } \\
\text { NB ON }\end{array}$ & 0 & 0 & 0 & 0 & 0 & 0 & 0 & 5 & 0 & 10 & 0 \\
\hline $\begin{array}{l}\text { Tassajara Creek } \\
\text { SB ON }\end{array}$ & 0 & 0 & 0 & 0 & 0 & 0 & 5 & 0 & 0 & 0 & 15 \\
\hline US 101 End & 0 & 0 & 0 & 0 & 0 & 0 & 0 & 0 & 0 & 0 & 0 \\
\hline
\end{tabular}

\begin{tabular}{|c|c|c|c|c|c|c|c|c|c|c|c|c|c|}
\hline $\begin{array}{c}\text { SOUTHBOU } \\
\text { ND } \\
\text { Network } 1 \\
\end{array}$ & $\begin{array}{l}\text { US } \\
101 \\
\text { Start } \\
\end{array}$ & $\begin{array}{l}\mathrm{JCT} \\
58\end{array}$ & $\begin{array}{l}\text { Tassajar } \\
\text { a Creek } \\
\text { NB Off }\end{array}$ & $\begin{array}{l}\text { Tassajar } \\
\text { a Creek } \\
\text { SB Off }\end{array}$ & $\begin{array}{l}\text { Cuesta } \\
\text { Springs }\end{array}$ & $\begin{array}{l}\text { TV } \\
\text { Road }\end{array}$ & Old 101 & $\begin{array}{l}\text { Old Stage } \\
\text { Coach SB } \\
\text { Off } \\
\end{array}$ & $\begin{array}{l}\text { Haw } \\
\text { k Hill }\end{array}$ & Miossi & Monterey & $\begin{array}{l}\text { US } \\
101 \\
\text { South } \\
\end{array}$ & \begin{tabular}{|l|} 
US \\
101 \\
North \\
\end{tabular} \\
\hline US 101 Start & 0 & 0 & 15 & 15 & 10 & 10 & 5 & 5 & 5 & 5 & 280 & 1,250 & 0 \\
\hline JCT 58 & 0 & 0 & 0 & 0 & 0 & 0 & 0 & 0 & 0 & 0 & 30 & 160 & 0 \\
\hline $\begin{array}{l}\text { Tassajara } \\
\text { Creek SB ON }\end{array}$ & 0 & 0 & 0 & 0 & 0 & 0 & 0 & 0 & 0 & 0 & 0 & 0 & 0 \\
\hline $\begin{array}{l}\text { Tassajara } \\
\text { Creek NB ON }\end{array}$ & 0 & 0 & 0 & 0 & 0 & 0 & 0 & 0 & 0 & 0 & 0 & 0 & 0 \\
\hline $\begin{array}{l}\text { Cuesta } \\
\text { Springs }\end{array}$ & 0 & 0 & 0 & 0 & 0 & 0 & 0 & 0 & 0 & 0 & 5 & 5 & 0 \\
\hline TV Road & 0 & 0 & 0 & 0 & 0 & 0 & 0 & 0 & 0 & 0 & 5 & 10 & 0 \\
\hline $\begin{array}{l}\text { Old Stage } \\
\text { Coach SB } \\
\text { ON }\end{array}$ & 0 & 0 & 0 & 0 & 0 & 0 & 0 & 0 & 0 & 0 & 3 & 10 & 0 \\
\hline
\end{tabular}




\begin{tabular}{|c|c|c|c|c|c|c|c|c|c|c|c|c|}
\hline $\begin{array}{l}\text { Old Stage } \\
\text { Coach NB } \\
\text { ON }\end{array}$ & 0 & 0 & 0 & 0 & 0 & 0 & 0 & 0 & 0 & 0 & 0 & 5 \\
\hline Hawk Hill & 0 & 0 & 0 & 0 & 0 & 0 & 0 & 0 & 0 & 0 & 10 & 0 \\
\hline US 101 End & 0 & 0 & 0 & 0 & 0 & 0 & 0 & 0 & 0 & 0 & 0 & 0 \\
\hline $\begin{array}{c}\text { NORTHBOU } \\
\text { ND } \\
\text { Network } 2 \\
\end{array}$ & \begin{tabular}{l|} 
US \\
101 \\
Start \\
\end{tabular} & Monterey & $\begin{array}{l}\text { Fox } \\
\text { Hollow }\end{array}$ & $\begin{array}{l}\text { Reservoir } \\
\text { Canyon }\end{array}$ & $\begin{array}{l}\text { Vista Del } \\
\text { Ciudad }\end{array}$ & $\begin{array}{l}\text { Cuesta } \\
\text { Springs }\end{array}$ & $\begin{array}{l}\text { Tassajara } \\
\text { Creek East }\end{array}$ & & $\begin{array}{l}\text { assajara } \\
\text { eek West }\end{array}$ & $\begin{array}{l}\text { Junction } \\
58 \text { East }\end{array}$ & $\begin{array}{l}\text { US } 101 \\
\text { North }\end{array}$ & $\begin{array}{l}\text { US } 101 \\
\text { South }\end{array}$ \\
\hline US 101 Start & 0 & 0 & 5 & 5 & 5 & 5 & 5 & & 5 & 149 & 2,000 & 0 \\
\hline Monterey & 0 & 0 & 1 & 2 & 2 & 5 & 5 & & 5 & 40 & 280 & 0 \\
\hline Fox Hollow & 0 & 0 & 0 & 0 & 0 & 0 & 0 & & 0 & 0 & 10 & 0 \\
\hline $\begin{array}{l}\text { Reservoir } \\
\text { Canyon }\end{array}$ & 0 & 0 & 0 & 0 & 0 & 0 & 0 & & 0 & 0 & 10 & 0 \\
\hline $\begin{array}{l}\text { Vista Del } \\
\text { Ciudad }\end{array}$ & 0 & 0 & 0 & 0 & 0 & 0 & 0 & & 0 & 0 & 10 & 0 \\
\hline $\begin{array}{l}\text { Cuesta } \\
\text { Springs }\end{array}$ & 0 & 0 & 0 & 0 & 0 & 0 & 0 & & 0 & 0 & 10 & 0 \\
\hline $\begin{array}{l}\text { Tassajara } \\
\text { Creek NB ON }\end{array}$ & 0 & 0 & 0 & 0 & 0 & 0 & 0 & & 5 & 0 & 15 & 0 \\
\hline $\begin{array}{l}\text { Tassajara } \\
\text { Creek SB ON }\end{array}$ & 0 & 0 & 0 & 0 & 0 & 0 & 5 & & 0 & 0 & 0 & 15 \\
\hline US 101 End & 0 & 0 & 0 & 0 & 0 & 0 & 0 & & 0 & 0 & 0 & 0 \\
\hline
\end{tabular}

\begin{tabular}{|c|c|c|c|c|c|c|c|c|c|c|c|c|c|}
\hline $\begin{array}{c}\text { SOUTHBOU } \\
\text { ND }\end{array}$ & $\begin{array}{l}\text { US } \\
101 \\
\text { Start }\end{array}$ & $\begin{array}{l}\mathrm{JC} \\
\mathrm{T} \\
58\end{array}$ & $\begin{array}{l}\text { Tassajar } \\
\text { a Creek } \\
\text { NB Off }\end{array}$ & $\begin{array}{l}\text { Tassajar } \\
\text { a Creek } \\
\text { SB Off }\end{array}$ & $\begin{array}{l}\text { Cuest } \\
\text { a } \\
\text { Spring } \\
\text { s }\end{array}$ & $\begin{array}{l}\text { TV } \\
\text { Road }\end{array}$ & Old 101 & $\begin{array}{l}\text { Old Stage } \\
\text { Coach SB } \\
\text { Off }\end{array}$ & $\begin{array}{l}\text { Hawk } \\
\text { Hill }\end{array}$ & Miossi & Monterey & $\begin{array}{l}\text { US } 101 \\
\text { South }\end{array}$ & $\begin{array}{l}\text { US } 101 \\
\text { North }\end{array}$ \\
\hline US 101 Start & 0 & 0 & 2 & 2 & 3 & 1 & 2 & 3 & 1 & 1 & 300 & 1550 & 0 \\
\hline JCT 58 & 0 & 0 & 0 & 0 & 0 & 0 & 0 & 0 & 0 & 0 & 30 & 200 & 0 \\
\hline $\begin{array}{l}\text { Tassajara } \\
\text { Creek SB ON }\end{array}$ & 0 & 0 & 0 & 0 & 0 & 0 & 0 & 0 & 0 & 0 & 0 & 0 & 0 \\
\hline $\begin{array}{l}\text { Tassajara } \\
\text { Creek NB ON }\end{array}$ & 0 & 0 & 0 & 0 & 0 & 0 & 0 & 0 & 0 & 0 & 0 & 0 & 0 \\
\hline $\begin{array}{l}\text { Cuesta } \\
\text { Springs }\end{array}$ & 0 & 0 & 0 & 0 & 0 & 0 & 0 & 0 & 0 & 0 & 5 & 10 & 0 \\
\hline TV Road & 0 & 0 & 0 & 0 & 0 & 0 & 0 & 0 & 0 & 0 & 5 & 10 & 0 \\
\hline
\end{tabular}




\begin{tabular}{|c|c|c|c|c|c|c|c|c|c|c|c|c|c|}
\hline $\begin{array}{l}\text { Old Stage } \\
\text { Coach SB } \\
\text { ON }\end{array}$ & 0 & 0 & 0 & 0 & 0 & 0 & 0 & 0 & 0 & 0 & 3 & 10 & 0 \\
\hline $\begin{array}{l}\text { Old Stage } \\
\text { Coach NB } \\
\text { ON }\end{array}$ & 0 & 0 & 0 & 0 & 0 & 0 & 0 & 0 & 0 & 0 & 0 & 0 & 27 \\
\hline Hawk Hill & 0 & 0 & 0 & 0 & 0 & 0 & 0 & 0 & 0 & 0 & 1 & 10 & 0 \\
\hline US 101 End & 0 & 0 & 0 & 0 & 0 & 0 & 0 & 0 & 0 & 0 & 0 & 0 & 0 \\
\hline
\end{tabular}


APPENDIX C: VISSIM DATA COLLECTION OUTPUT

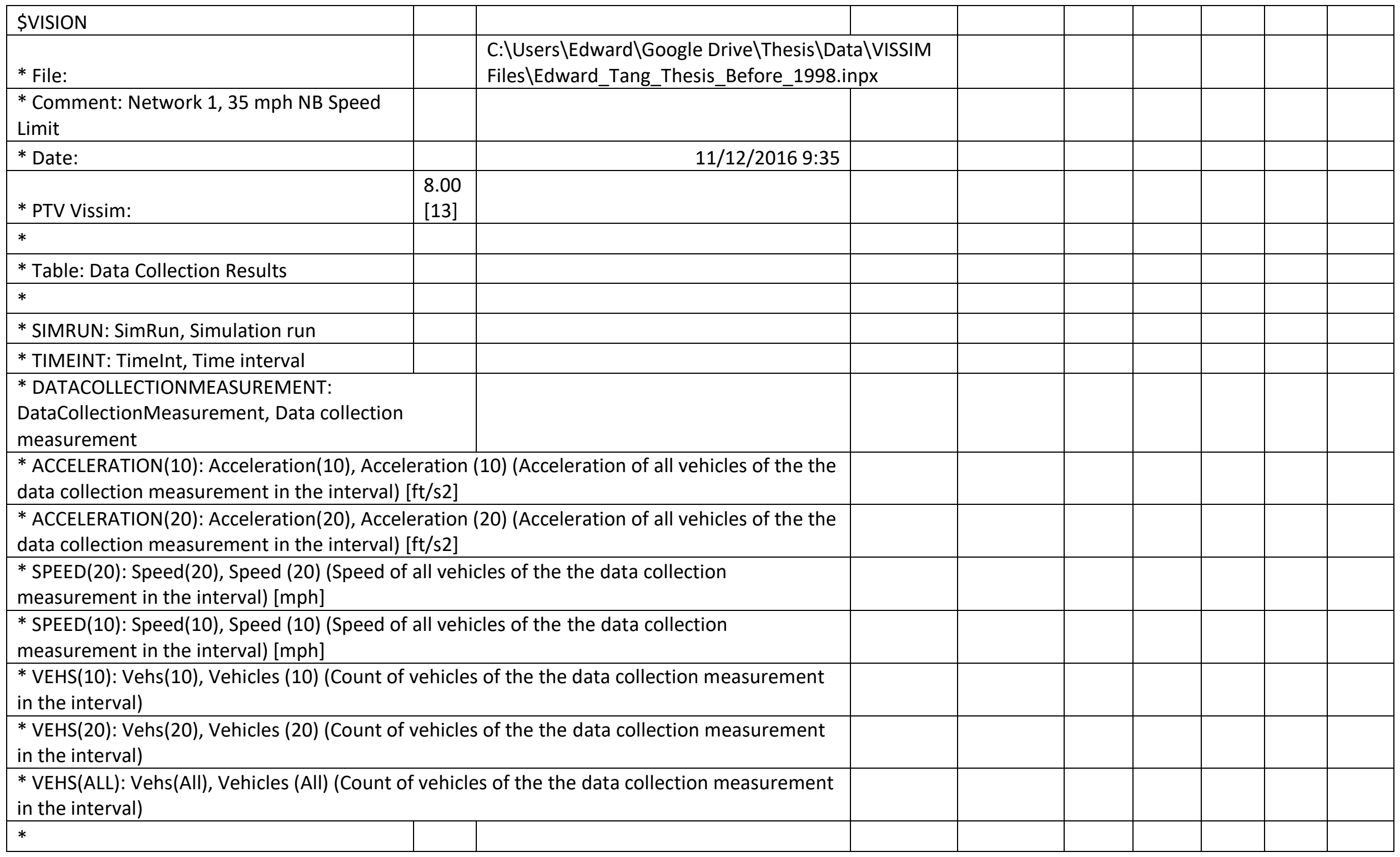




\begin{tabular}{|c|c|c|c|c|c|c|c|c|c|}
\hline * SimRun & $\begin{array}{l}\text { Tim } \\
\text { elnt }\end{array}$ & DataCollectionMeasurement & $\begin{array}{l}\text { Accelerati } \\
\text { on(10) }\end{array}$ & $\begin{array}{l}\text { Accelerati } \\
\text { on(20) }\end{array}$ & $\begin{array}{l}\text { Spee } \\
d(20)\end{array}$ & $\begin{array}{l}\text { Spee } \\
d(10)\end{array}$ & $\begin{array}{l}\text { Vehs } \\
(10)\end{array}$ & $\begin{array}{l}\text { Vehs } \\
(20)\end{array}$ & $\begin{array}{l}\text { Vehs } \\
\text { (All) }\end{array}$ \\
\hline \multicolumn{10}{|l|}{ * } \\
\hline $\begin{array}{l}\text { \$DATACOLLECTIONMEASUREMENTEVALUAT } \\
\text { ION:SIMRUN }\end{array}$ & $\begin{array}{l}\text { TIM } \\
\text { EINT }\end{array}$ & DATACOLLECTIONMEASUREMENT & $\begin{array}{l}\text { ACCELER } \\
\text { ATION(10 } \\
\text { ) }\end{array}$ & $\begin{array}{l}\text { ACCELER } \\
\text { ATION }(20 \\
1\end{array}$ & $\begin{array}{l}\text { SPEE } \\
\mathrm{D}(20)\end{array}$ & $\begin{array}{l}\text { SPEE } \\
\mathrm{D}(10)\end{array}$ & $\begin{array}{l}\text { VEH } \\
\mathrm{S}(10 \\
)\end{array}$ & $\begin{array}{l}\text { VEH } \\
S(20 \\
)\end{array}$ & $\begin{array}{l}\text { VEHS } \\
\text { (ALL) }\end{array}$ \\
\hline 1 & $\begin{array}{l}600- \\
420 \\
0\end{array}$ & 1: NB 101 After Monterey & 0.32 & 0.48 & $\begin{array}{r}52.2 \\
3\end{array}$ & $\begin{array}{r}60.0 \\
7\end{array}$ & $\begin{array}{r}266 \\
8\end{array}$ & 242 & 2910 \\
\hline 1 & $\begin{array}{l}600- \\
420 \\
0 \\
\end{array}$ & 2: JCT 58 NB Off Ramp & 0.93 & 0.32 & $\begin{array}{r}55.7 \\
2\end{array}$ & $\begin{array}{r}63.1 \\
4\end{array}$ & 170 & 14 & 184 \\
\hline 1 & $\begin{array}{l}600- \\
420 \\
0\end{array}$ & 3: NB 101 End & 0.42 & 0.2 & $\begin{array}{r}54.2 \\
8\end{array}$ & $\begin{array}{r}60.4 \\
8\end{array}$ & $\begin{array}{r}214 \\
9\end{array}$ & 196 & 2345 \\
\hline 1 & $\begin{array}{l}600- \\
420 \\
0 \\
\end{array}$ & 4: SB 101 After JCT 58 & -0.03 & -0.41 & $\begin{array}{r}56.6 \\
9 \\
\end{array}$ & $\begin{array}{r}63.5 \\
8 \\
\end{array}$ & $\begin{array}{r}170 \\
3 \\
\end{array}$ & 161 & 1864 \\
\hline 1 & $\begin{array}{l}600- \\
420 \\
0 \\
\end{array}$ & 5: Monterey SB Off Ramp & 0.84 & 0.32 & $\begin{array}{r}56.4 \\
1\end{array}$ & $\begin{array}{r}63.6 \\
6\end{array}$ & 312 & 28 & 340 \\
\hline 1 & $\begin{array}{l}600- \\
420 \\
0\end{array}$ & 6: SB $101 \mathrm{End}$ & 0.44 & 0.37 & $\begin{array}{r}56.1 \\
6\end{array}$ & $\begin{array}{r}62.9 \\
2\end{array}$ & $\begin{array}{r}138 \\
5\end{array}$ & 137 & 1522 \\
\hline 1 & $\begin{array}{l}600- \\
420 \\
0 \\
\end{array}$ & 7: NB Truck Lane & 0.01 & 0.15 & $\begin{array}{r}21.1 \\
4 \\
\end{array}$ & $\begin{array}{r}46.0 \\
6 \\
\end{array}$ & $\begin{array}{r}250 \\
1 \\
\end{array}$ & 232 & 2733 \\
\hline 1 & $\begin{array}{l}600- \\
420 \\
0 \\
\end{array}$ & 8: SB Truck Lane & -0.09 & 0.2 & $\begin{array}{r}30.8 \\
5 \\
\end{array}$ & $\begin{array}{r}61.3 \\
7 \\
\end{array}$ & $\begin{array}{r}167 \\
9 \\
\end{array}$ & 166 & 1845 \\
\hline 2 & $\begin{array}{l}600- \\
420 \\
0\end{array}$ & 1: NB 101 After Monterey & 0.21 & 0.33 & $\begin{array}{r}51.2 \\
8\end{array}$ & $\begin{array}{r}60.0 \\
1\end{array}$ & $\begin{array}{r}266 \\
9\end{array}$ & 258 & 2927 \\
\hline
\end{tabular}




\begin{tabular}{|c|c|c|c|c|c|c|c|c|c|}
\hline 2 & \begin{tabular}{|l|l|}
$600-$ \\
420 \\
2 & 0
\end{tabular} & 2: JCT 58 NB Off Ramp & 1.07 & 0.38 & $\begin{array}{r}56.7 \\
5\end{array}$ & $\begin{array}{r}63.0 \\
6\end{array}$ & 182 & 20 & 202 \\
\hline 2 & \begin{tabular}{|l|l|}
$600-$ \\
420 \\
2 & 0 \\
\end{tabular} & 3: NB 101 End & 0.62 & 0.34 & 52.3 & $\begin{array}{r}59.4 \\
3\end{array}$ & $\begin{array}{r}223 \\
7 \\
\end{array}$ & 197 & 2434 \\
\hline 2 & \begin{tabular}{|l|l|}
$600-$ \\
420 \\
2 & 0
\end{tabular} & 4: SB 101 After JCT 58 & 0.04 & -0.35 & $\begin{array}{r}55.8 \\
4\end{array}$ & $\begin{array}{r}63.5 \\
7\end{array}$ & $\begin{array}{r}158 \\
2\end{array}$ & 139 & 1721 \\
\hline 2 & \begin{tabular}{|l}
$600-$ \\
420 \\
0
\end{tabular} & 5: Monterey SB Off Ramp & 0.93 & 0.26 & 56 & $\begin{array}{r}63.0 \\
5\end{array}$ & 265 & 21 & 286 \\
\hline 2 & \begin{tabular}{|l|l|}
$600-$ \\
420 \\
0
\end{tabular} & 6: SB 101 End & 0.42 & 0.39 & $\begin{array}{r}55.5 \\
3\end{array}$ & $\begin{array}{r}63.0 \\
4\end{array}$ & $\begin{array}{r}128 \\
7\end{array}$ & 102 & 1389 \\
\hline 2 & \begin{tabular}{|l|l|}
$600-$ \\
420 \\
0
\end{tabular} & 7: NB Truck Lane & 0.03 & -0.09 & 21.1 & $\begin{array}{r}45.5 \\
9\end{array}$ & $\begin{array}{r}254 \\
1\end{array}$ & 247 & 2788 \\
\hline 2 & \begin{tabular}{|l|}
$600-$ \\
420 \\
0
\end{tabular} & 8: SB Truck Lane & -0.09 & 0.22 & $\begin{array}{r}30.0 \\
2 \\
\end{array}$ & $\begin{array}{r}62.0 \\
9 \\
\end{array}$ & $\begin{array}{r}154 \\
8 \\
\end{array}$ & 129 & 1677 \\
\hline 3 & \begin{tabular}{|l|l}
$600-$ \\
420 \\
0
\end{tabular} & 1: NB 101 After Monterey & 0.22 & 0.59 & $\begin{array}{r}49.9 \\
9\end{array}$ & $\begin{array}{r}59.5 \\
7\end{array}$ & $\begin{array}{r}265 \\
3\end{array}$ & 285 & 2938 \\
\hline 3 & \begin{tabular}{|l|l}
$600-$ \\
420 \\
0
\end{tabular} & 2: JCT 58 NB Off Ramp & 0.68 & 0.26 & $\begin{array}{r}57.8 \\
2\end{array}$ & 63.8 & 194 & 16 & 210 \\
\hline 3 & \begin{tabular}{|l|l|}
$600-$ \\
420 \\
0
\end{tabular} & 3: NB 101 End & 0.42 & 0.19 & $\begin{array}{r}54.8 \\
7\end{array}$ & 60.9 & $\begin{array}{r}212 \\
9\end{array}$ & 207 & 2336 \\
\hline 3 & \begin{tabular}{|l}
$600-$ \\
420 \\
0
\end{tabular} & 4: SB 101 After JCT 58 & 0.02 & -0.31 & $\begin{array}{r}55.9 \\
4\end{array}$ & $\begin{array}{r}63.5 \\
9\end{array}$ & $\begin{array}{r}167 \\
0\end{array}$ & 162 & 1832 \\
\hline 3 & \begin{tabular}{|l}
$600-$ \\
420 \\
0
\end{tabular} & 5: Monterey SB Off Ramp & 0.71 & 0.37 & $\begin{array}{r}56.8 \\
9\end{array}$ & $\begin{array}{r}63.9 \\
5\end{array}$ & 321 & 22 & 343 \\
\hline
\end{tabular}




\begin{tabular}{|c|c|c|c|c|c|c|c|c|c|}
\hline 3 & $\begin{array}{l}600- \\
420 \\
0 \\
\end{array}$ & 6: SB 101 End & 0.4 & 0.36 & $\begin{array}{r}55.6 \\
9 \\
\end{array}$ & $\begin{array}{r}63.2 \\
9 \\
\end{array}$ & $\begin{array}{r}133 \\
4 \\
\end{array}$ & 114 & 1448 \\
\hline 3 & $\begin{array}{l}600- \\
420 \\
0\end{array}$ & 7: NB Truck Lane & -0.07 & -0.01 & $\begin{array}{r}20.8 \\
3 \\
\end{array}$ & $\begin{array}{r}46.3 \\
6 \\
\end{array}$ & $\begin{array}{r}253 \\
6\end{array}$ & 275 & 2811 \\
\hline 3 & $\begin{array}{l}600- \\
420 \\
0\end{array}$ & 8: SB Truck Lane & -0.02 & 0.15 & $\begin{array}{r}30.6 \\
3 \\
\end{array}$ & $\begin{array}{r}61.9 \\
4 \\
\end{array}$ & $\begin{array}{r}165 \\
5 \\
\end{array}$ & 153 & 1808 \\
\hline 4 & $\begin{array}{l}600- \\
420 \\
0 \\
\end{array}$ & 1: NB 101 After Monterey & 0.31 & 0.4 & $\begin{array}{r}51.8 \\
1 \\
\end{array}$ & $\begin{array}{r}60.0 \\
7 \\
\end{array}$ & $\begin{array}{r}267 \\
4 \\
\end{array}$ & 249 & 2923 \\
\hline 4 & $\begin{array}{l}600- \\
420 \\
0\end{array}$ & 2: JCT 58 NB Off Ramp & 1.01 & 0.24 & $\begin{array}{r}58.6 \\
9 \\
\end{array}$ & $\begin{array}{r}63.7 \\
6 \\
\end{array}$ & 155 & 20 & 175 \\
\hline 4 & $\begin{array}{l}600- \\
420 \\
0 \\
\end{array}$ & 3: NB 101 End & 0.33 & -0.03 & 55.8 & 60.7 & $\begin{array}{r}220 \\
5 \\
\end{array}$ & 181 & 2386 \\
\hline 4 & $\begin{array}{l}\text { 600- } \\
420 \\
0 \\
\end{array}$ & 4: SB 101 After JCT 58 & 0.03 & -0.37 & $\begin{array}{r}56.0 \\
4 \\
\end{array}$ & $\begin{array}{r}63.9 \\
5 \\
\end{array}$ & $\begin{array}{r}158 \\
4 \\
\end{array}$ & 129 & 1713 \\
\hline 4 & $\begin{array}{l}600- \\
420 \\
0\end{array}$ & 5: Monterey SB Off Ramp & 0.73 & 0.16 & 56.8 & $\begin{array}{r}63.8 \\
6\end{array}$ & 300 & 19 & 319 \\
\hline 4 & $\begin{array}{l}600- \\
420 \\
0 \\
\end{array}$ & 6: SB 101 End & 0.31 & 0.46 & 55.9 & 63.3 & $\begin{array}{r}127 \\
8 \\
\end{array}$ & 106 & 1384 \\
\hline 4 & $\begin{array}{l}600- \\
420 \\
0 \\
\end{array}$ & 7: NB Truck Lane & 0.06 & -0.02 & $\begin{array}{r}21.1 \\
8 \\
\end{array}$ & $\begin{array}{r}46.6 \\
4 \\
\end{array}$ & $\begin{array}{r}253 \\
5 \\
\end{array}$ & 238 & 2773 \\
\hline 4 & $\begin{array}{l}600- \\
420 \\
0 \\
\end{array}$ & 8: SB Truck Lane & -0.07 & 0.12 & $\begin{array}{r}30.6 \\
6 \\
\end{array}$ & $\begin{array}{r}61.6 \\
7 \\
\end{array}$ & $\begin{array}{r}158 \\
6 \\
\end{array}$ & 128 & 1714 \\
\hline 5 & $\begin{array}{l}600- \\
420 \\
0 \\
\end{array}$ & 1: NB 101 After Monterey & 0.37 & 0.49 & $\begin{array}{r}50.8 \\
7 \\
\end{array}$ & $\begin{array}{r}59.6 \\
2 \\
\end{array}$ & $\begin{array}{r}265 \\
9 \\
\end{array}$ & 236 & 2895 \\
\hline
\end{tabular}




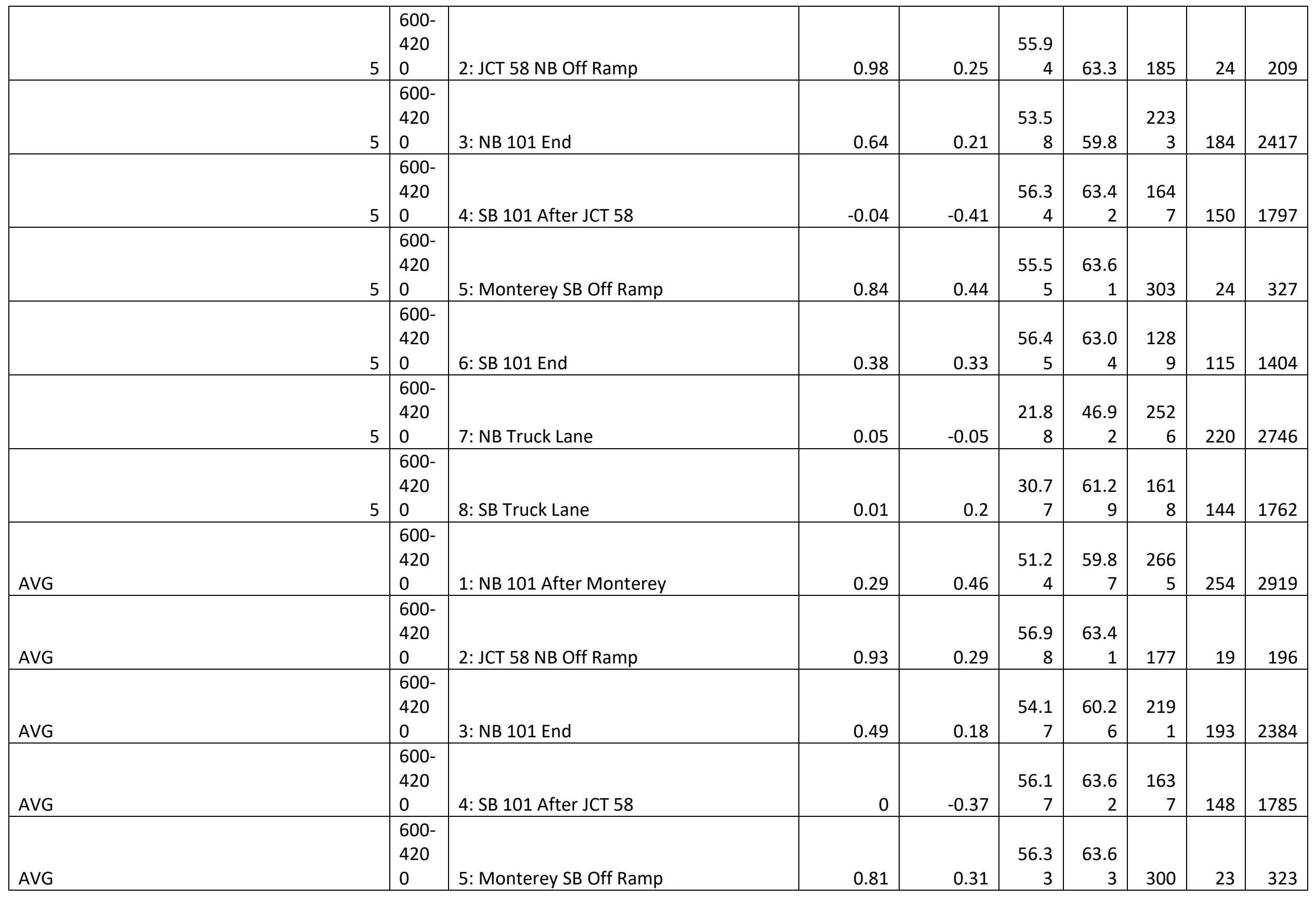




\begin{tabular}{|c|c|c|c|c|c|c|c|c|c|}
\hline AVG & $\begin{array}{l}600- \\
420 \\
0 \\
\end{array}$ & 6: SB 101 End & 0.39 & 0.38 & $\begin{array}{r}55.9 \\
5 \\
\end{array}$ & $\begin{array}{r}63.1 \\
2 \\
\end{array}$ & $\begin{array}{r}131 \\
5 \\
\end{array}$ & 115 & 1429 \\
\hline AVG & $\begin{array}{l}600- \\
420 \\
0 \\
\end{array}$ & 7: NB Truck Lane & 0.02 & -0.01 & $\begin{array}{r}21.2 \\
3\end{array}$ & $\begin{array}{r}46.3 \\
1 \\
\end{array}$ & $\begin{array}{r}252 \\
8 \\
\end{array}$ & 242 & 2770 \\
\hline AVG & $\begin{array}{l}600- \\
420 \\
0 \\
\end{array}$ & 8: SB Truck Lane & -0.05 & 0.18 & $\begin{array}{r}30.5 \\
8 \\
\end{array}$ & $\begin{array}{r}61.6 \\
7 \\
\end{array}$ & $\begin{array}{r}161 \\
7 \\
\end{array}$ & 144 & 1761 \\
\hline STDDEV & $\begin{array}{l}600- \\
420 \\
0 \\
\end{array}$ & 1: NB 101 After Monterey & 0.07 & 0.1 & 0.87 & 0.25 & 8 & 19 & 17 \\
\hline STDDEV & $\begin{array}{l}600- \\
420 \\
0\end{array}$ & 2: JCT 58 NB Off Ramp & 0.15 & 0.06 & 1.26 & 0.35 & 15 & 4 & 16 \\
\hline STDDEV & $\begin{array}{l}600- \\
420 \\
0\end{array}$ & 3: NB 101 End & 0.13 & 0.13 & 1.32 & 0.62 & 49 & 11 & 43 \\
\hline STDDEV & $\begin{array}{l}600- \\
420 \\
0\end{array}$ & 4: SB 101 After JCT 58 & 0.04 & 0.04 & 0.34 & 0.2 & 53 & 14 & 67 \\
\hline STDDEV & $\begin{array}{l}600- \\
420 \\
0 \\
\end{array}$ & 5: Monterey SB Off Ramp & 0.09 & 0.11 & 0.56 & 0.35 & 21 & 3 & 23 \\
\hline STDDEV & $\begin{array}{l}600- \\
420 \\
0 \\
\end{array}$ & 6: SB 101 End & 0.05 & 0.05 & 0.37 & 0.17 & 45 & 14 & 58 \\
\hline STDDEV & $\begin{array}{l}600- \\
420 \\
0 \\
\end{array}$ & 7: NB Truck Lane & 0.05 & 0.09 & 0.39 & 0.52 & 16 & 21 & 31 \\
\hline STDDEV & $\begin{array}{l}600- \\
420 \\
0\end{array}$ & 8: SB Truck Lane & 0.04 & 0.04 & 0.33 & 0.35 & 52 & 16 & 68 \\
\hline MIN & $\begin{array}{l}600- \\
420 \\
0\end{array}$ & 1: NB 101 After Monterey & 0.21 & 0.33 & $\begin{array}{r}49.9 \\
9 \\
\end{array}$ & $\begin{array}{r}59.5 \\
7 \\
\end{array}$ & $\begin{array}{r}265 \\
3 \\
\end{array}$ & 236 & 2895 \\
\hline
\end{tabular}




\begin{tabular}{|c|c|c|c|c|c|c|c|c|c|}
\hline MIN & $\begin{array}{l}600- \\
420 \\
0\end{array}$ & 2: JCT 58 NB Off Ramp & 0.68 & 0.24 & $\begin{array}{r}55.7 \\
2\end{array}$ & $\begin{array}{r}63.0 \\
6\end{array}$ & 155 & 14 & 175 \\
\hline MIN & $\begin{array}{l}600- \\
420 \\
0\end{array}$ & 3: NB 101 End & 0.33 & -0.03 & 52.3 & $\begin{array}{r}59.4 \\
3\end{array}$ & $\begin{array}{r}212 \\
9\end{array}$ & 181 & 2336 \\
\hline MIN & $\begin{array}{l}600- \\
420 \\
0\end{array}$ & 4: SB 101 After JCT 58 & -0.04 & -0.41 & $\begin{array}{r}55.8 \\
4\end{array}$ & $\begin{array}{r}63.4 \\
2\end{array}$ & $\begin{array}{r}158 \\
2\end{array}$ & 129 & 1713 \\
\hline MIN & $\begin{array}{l}600- \\
420 \\
0 \\
\end{array}$ & 5: Monterey SB Off Ramp & 0.71 & 0.16 & $\begin{array}{r}55.5 \\
5\end{array}$ & $\begin{array}{r}63.0 \\
5\end{array}$ & 265 & 19 & 286 \\
\hline MIN & $\begin{array}{l}600- \\
420 \\
0\end{array}$ & 6: SB 101 End & 0.31 & 0.33 & $\begin{array}{r}55.5 \\
3\end{array}$ & $\begin{array}{r}62.9 \\
2\end{array}$ & $\begin{array}{r}127 \\
8\end{array}$ & 102 & 1384 \\
\hline MIN & $\begin{array}{l}600- \\
420 \\
0\end{array}$ & 7: NB Truck Lane & -0.07 & -0.09 & $\begin{array}{r}20.8 \\
3\end{array}$ & $\begin{array}{r}45.5 \\
9\end{array}$ & $\begin{array}{r}250 \\
1\end{array}$ & 220 & 2733 \\
\hline MIN & $\begin{array}{l}600- \\
420 \\
0\end{array}$ & 8: SB Truck Lane & -0.09 & 0.12 & $\begin{array}{r}30.0 \\
2\end{array}$ & $\begin{array}{r}61.2 \\
9\end{array}$ & $\begin{array}{r}154 \\
8\end{array}$ & 128 & 1677 \\
\hline MAX & $\begin{array}{l}600- \\
420 \\
0\end{array}$ & 1: NB 101 After Monterey & 0.37 & 0.59 & $\begin{array}{r}52.2 \\
3\end{array}$ & $\begin{array}{r}60.0 \\
7\end{array}$ & $\begin{array}{r}267 \\
4\end{array}$ & 285 & 2938 \\
\hline MAX & $\begin{array}{l}600- \\
420 \\
0\end{array}$ & 2: JCT 58 NB Off Ramp & 1.07 & 0.38 & $\begin{array}{r}58.6 \\
9\end{array}$ & 63.8 & 194 & 24 & 210 \\
\hline MAX & $\begin{array}{l}600- \\
420 \\
0\end{array}$ & 3: NB 101 End & 0.64 & 0.34 & 55.8 & 60.9 & $\begin{array}{r}223 \\
7\end{array}$ & 207 & 2434 \\
\hline MAX & $\begin{array}{l}600- \\
420 \\
0\end{array}$ & 4: SB 101 After JCT 58 & 0.04 & -0.31 & $\begin{array}{r}56.6 \\
9\end{array}$ & $\begin{array}{r}63.9 \\
5\end{array}$ & $\begin{array}{r}170 \\
3\end{array}$ & 162 & 1864 \\
\hline MAX & $\begin{array}{l}600- \\
420 \\
0\end{array}$ & 5: Monterey SB Off Ramp & 0.93 & 0.44 & $\begin{array}{r}56.8 \\
9\end{array}$ & $\begin{array}{r}63.9 \\
5\end{array}$ & 321 & 28 & 343 \\
\hline
\end{tabular}




\begin{tabular}{|c|c|c|c|c|c|c|c|c|c|}
\hline MAX & $\begin{array}{l}600- \\
420 \\
0 \\
\end{array}$ & 6: SB 101 End & 0.44 & 0.46 & $\begin{array}{r}56.4 \\
5 \\
\end{array}$ & 63.3 & $\begin{array}{r}138 \\
5 \\
\end{array}$ & 137 & 1522 \\
\hline MAX & $\begin{array}{l}\text { 600- } \\
420 \\
0\end{array}$ & 7: NB Truck Lane & 0.06 & 0.15 & $\begin{array}{r}21.8 \\
8 \\
\end{array}$ & $\begin{array}{r}46.9 \\
2 \\
\end{array}$ & $\begin{array}{r}254 \\
1 \\
\end{array}$ & 275 & 2811 \\
\hline MAX & $\begin{array}{l}600- \\
420 \\
0\end{array}$ & 8: SB Truck Lane & 0.01 & 0.22 & $\begin{array}{r}30.8 \\
5\end{array}$ & $\begin{array}{r}62.0 \\
9 \\
\end{array}$ & $\begin{array}{r}167 \\
9 \\
\end{array}$ & 166 & 1845 \\
\hline
\end{tabular}

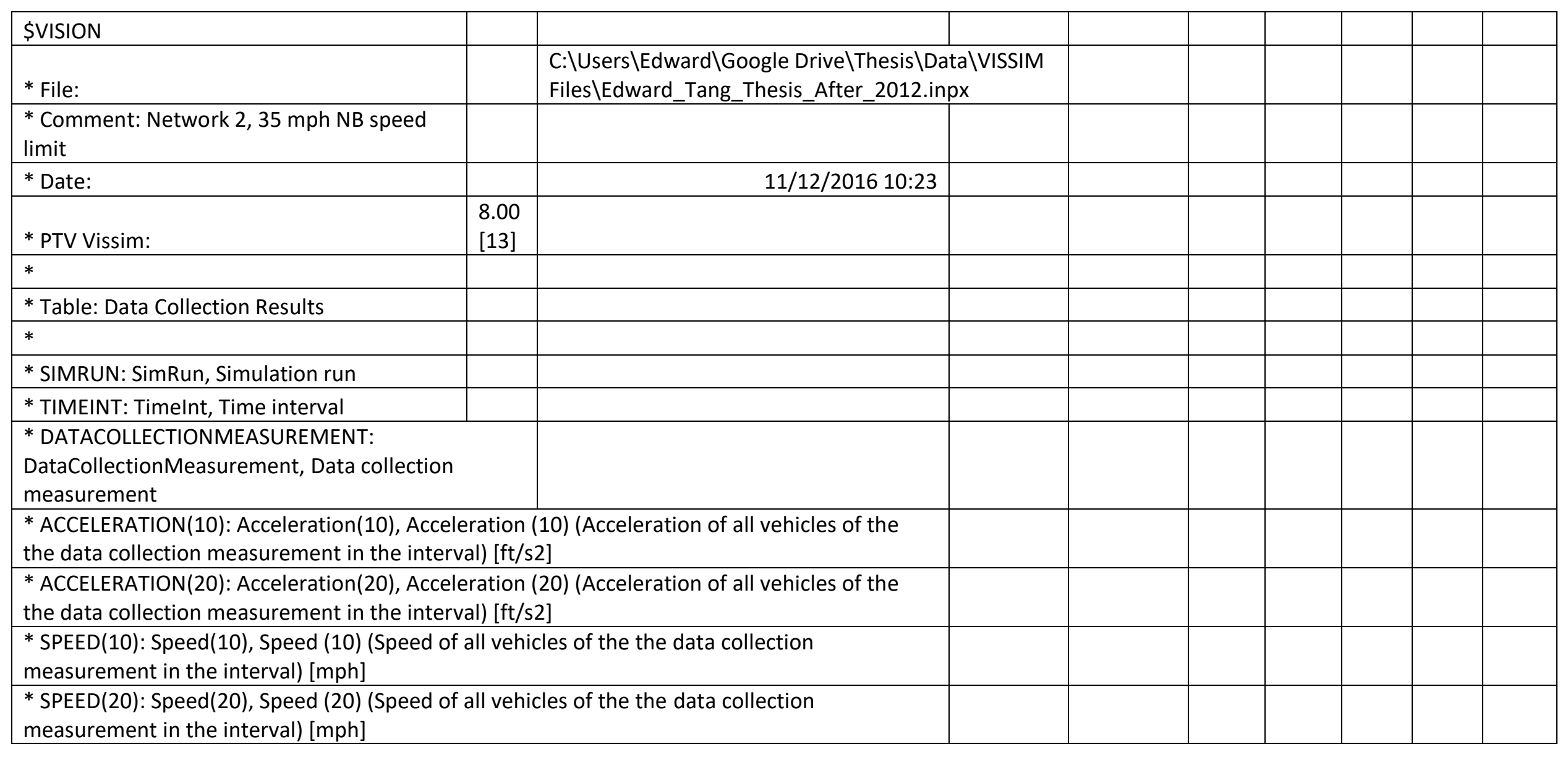




\begin{tabular}{|c|c|c|c|c|c|c|c|c|c|}
\hline \multicolumn{10}{|c|}{$\begin{array}{l}\text { * VEHS(10): Vehs(10), Vehicles (10) (Count of vehicles of the the data collection measurement } \\
\text { in the interval) }\end{array}$} \\
\hline \multicolumn{10}{|c|}{$\begin{array}{l}\text { * VEHS(20): Vehs(20), Vehicles (20) (Count of vehicles of the the data collection measurement } \\
\text { in the interval) }\end{array}$} \\
\hline \multicolumn{10}{|c|}{$\begin{array}{l}\text { * VEHS(ALL): Vehs(All), Vehicles (All) (Count of vehicles of the the data collection measurement } \\
\text { in the interval) }\end{array}$} \\
\hline \multicolumn{10}{|l|}{$*$} \\
\hline * SimRun & $\begin{array}{l}\text { Tim } \\
\text { elnt }\end{array}$ & DataCollectionMeasurement & $\begin{array}{l}\text { Accelerati } \\
\text { on(10) }\end{array}$ & $\begin{array}{l}\text { Accelerati } \\
\text { on(20) }\end{array}$ & $\begin{array}{l}\text { Spee } \\
d(10)\end{array}$ & $\begin{array}{l}\text { Spee } \\
d(20)\end{array}$ & $\begin{array}{l}\text { Vehs } \\
(10)\end{array}$ & $\begin{array}{l}\text { Vehs } \\
(20)\end{array}$ & $\begin{array}{l}\text { Vehs } \\
\text { (All) }\end{array}$ \\
\hline \multicolumn{10}{|l|}{$*$} \\
\hline $\begin{array}{l}\text { \$DATACOLLECTIONMEASUREMENTEVALUAT } \\
\text { ION:SIMRUN }\end{array}$ & $\begin{array}{l}\text { TIM } \\
\text { EINT }\end{array}$ & DATACOLLECTIONMEASUREMENT & $\begin{array}{l}\text { ACCELER } \\
\text { ATION }(10 \\
)\end{array}$ & $\begin{array}{l}\text { ACCELER } \\
\operatorname{ATION}(20 \\
)\end{array}$ & $\begin{array}{l}\text { SPEE } \\
\mathrm{D}(10)\end{array}$ & $\begin{array}{l}\text { SPEE } \\
\mathrm{D}(20)\end{array}$ & $\begin{array}{l}\text { VEH } \\
\mathrm{S}(10 \\
)\end{array}$ & $\begin{array}{l}\text { VEH } \\
\text { S(20 } \\
)\end{array}$ & $\begin{array}{l}\text { VEHS } \\
(\mathrm{ALL})\end{array}$ \\
\hline 1 & $\begin{array}{l}600- \\
420 \\
0\end{array}$ & 1: NB 101 After Monterey & 0.27 & 0.43 & 61.5 & $\begin{array}{r}53.2 \\
6\end{array}$ & $\begin{array}{r}227 \\
1\end{array}$ & 223 & 2494 \\
\hline 1 & $\begin{array}{l}600- \\
420 \\
0\end{array}$ & 2: JCT 58 NB Off Ramp & 0.68 & 0.33 & 63.8 & $\begin{array}{r}56.5 \\
5\end{array}$ & 158 & 12 & 170 \\
\hline 1 & $\begin{array}{l}600- \\
420 \\
0\end{array}$ & 3: NB 101 End & 0.33 & 0.01 & $\begin{array}{r}60.7 \\
1\end{array}$ & $\begin{array}{r}55.2 \\
5\end{array}$ & $\begin{array}{r}209 \\
3\end{array}$ & 194 & 2287 \\
\hline 1 & $\begin{array}{l}600- \\
420 \\
0\end{array}$ & 4: SB 101 After JCT 58 & -0.03 & -0.36 & $\begin{array}{r}63.1 \\
4\end{array}$ & 55.6 & $\begin{array}{r}197 \\
2\end{array}$ & 200 & 2172 \\
\hline 1 & $\begin{array}{l}600- \\
420 \\
0\end{array}$ & 5: Monterey SB Off Ramp & 0.73 & 0.21 & $\begin{array}{r}63.9 \\
1\end{array}$ & $\begin{array}{r}57.3 \\
2\end{array}$ & 312 & 25 & 337 \\
\hline 1 & $\begin{array}{l}600- \\
420 \\
0\end{array}$ & 6: SB 101 End & 0.53 & 0.28 & $\begin{array}{r}62.2 \\
4\end{array}$ & 56.3 & $\begin{array}{r}167 \\
8\end{array}$ & 173 & 1851 \\
\hline 1 & $\begin{array}{l}600- \\
420 \\
0\end{array}$ & 7: NB Truck Lane & -0.02 & 0.04 & $\begin{array}{r}61.1 \\
8\end{array}$ & $\begin{array}{r}20.8 \\
7\end{array}$ & $\begin{array}{r}229 \\
7\end{array}$ & 218 & 2515 \\
\hline
\end{tabular}




\begin{tabular}{|c|c|c|c|c|c|c|c|c|c|}
\hline 1 & $\begin{array}{l}\text { 600- } \\
420 \\
0\end{array}$ & 8: SB Truck Lane & -0.02 & -0.11 & $\begin{array}{r}63.0 \\
8\end{array}$ & $\begin{array}{r}30.2 \\
6 \\
\end{array}$ & $\begin{array}{r}197 \\
8\end{array}$ & 207 & 2185 \\
\hline 2 & $\begin{array}{l}600- \\
420 \\
0\end{array}$ & 1: NB 101 After Monterey & 0.32 & 0.47 & $\begin{array}{r}60.6 \\
4\end{array}$ & $\begin{array}{r}51.3 \\
7\end{array}$ & $\begin{array}{r}229 \\
9\end{array}$ & 233 & 2532 \\
\hline 2 & \begin{tabular}{|l}
$600-$ \\
420 \\
0
\end{tabular} & 2: JCT 58 NB Off Ramp & 0.94 & 0.32 & $\begin{array}{r}63.0 \\
5\end{array}$ & $\begin{array}{r}56.4 \\
9\end{array}$ & 149 & 28 & 177 \\
\hline 2 & \begin{tabular}{|l|}
$600-$ \\
420 \\
0
\end{tabular} & 3: NB 101 End & 0.53 & 0.15 & $\begin{array}{r}59.6 \\
7\end{array}$ & $\begin{array}{r}53.9 \\
1\end{array}$ & $\begin{array}{r}215 \\
3 \\
\end{array}$ & 214 & 2367 \\
\hline 2 & \begin{tabular}{|l}
$600-$ \\
420 \\
0
\end{tabular} & 4: SB 101 After JCT 58 & 0.03 & -0.42 & $\begin{array}{r}63.3 \\
1\end{array}$ & $\begin{array}{r}56.0 \\
3\end{array}$ & $\begin{array}{r}185 \\
5\end{array}$ & 185 & 2040 \\
\hline 2 & $\begin{array}{l}600- \\
420 \\
0\end{array}$ & 5: Monterey SB Off Ramp & 0.88 & 0.18 & $\begin{array}{r}63.6 \\
8\end{array}$ & $\begin{array}{r}56.7 \\
6\end{array}$ & 284 & 21 & 305 \\
\hline 2 & $\begin{array}{l}600- \\
420 \\
0\end{array}$ & 6: SB 101 End & 0.41 & 0.26 & $\begin{array}{r}62.5 \\
3 \\
\end{array}$ & 55.4 & $\begin{array}{r}159 \\
1 \\
\end{array}$ & 149 & 1740 \\
\hline 2 & $\begin{array}{l}600- \\
420 \\
0\end{array}$ & 7: NB Truck Lane & 0.02 & 0.04 & $\begin{array}{r}60.4 \\
4\end{array}$ & $\begin{array}{r}21.2 \\
3\end{array}$ & $\begin{array}{r}228 \\
4\end{array}$ & 240 & 2524 \\
\hline 2 & $\begin{array}{l}600- \\
420 \\
0\end{array}$ & 8: SB Truck Lane & 0 & -0.06 & $\begin{array}{r}63.2 \\
7\end{array}$ & $\begin{array}{r}30.3 \\
8\end{array}$ & $\begin{array}{r}187 \\
5\end{array}$ & 182 & 2057 \\
\hline 3 & $\begin{array}{l}600- \\
420 \\
0\end{array}$ & 1: NB 101 After Monterey & 0.33 & 0.44 & $\begin{array}{r}61.2 \\
8\end{array}$ & $\begin{array}{r}51.7 \\
7\end{array}$ & $\begin{array}{r}226 \\
8\end{array}$ & 243 & 2511 \\
\hline 3 & $\begin{array}{l}600- \\
420 \\
0\end{array}$ & 2: JCT 58 NB Off Ramp & 0.96 & 0.51 & $\begin{array}{r}63.1 \\
9 \\
\end{array}$ & $\begin{array}{r}56.7 \\
5 \\
\end{array}$ & 165 & 15 & 180 \\
\hline 3 & $\begin{array}{l}600- \\
420 \\
0\end{array}$ & 3: NB 101 End & 0.49 & 0.25 & $\begin{array}{r}59.6 \\
7\end{array}$ & $\begin{array}{r}53.9 \\
4\end{array}$ & $\begin{array}{r}212 \\
3\end{array}$ & 221 & 2344 \\
\hline
\end{tabular}




\begin{tabular}{|c|c|c|c|c|c|c|c|c|c|}
\hline 3 & $\begin{array}{l}600- \\
420 \\
0\end{array}$ & 4: SB 101 After JCT 58 & 0.01 & -0.31 & $\begin{array}{r}62.9 \\
8\end{array}$ & $\begin{array}{r}54.6 \\
8\end{array}$ & $\begin{array}{r}194 \\
1 \\
\end{array}$ & 201 & 2142 \\
\hline 3 & $\begin{array}{l}600- \\
420 \\
0\end{array}$ & 5: Monterey SB Off Ramp & 0.83 & 0.25 & $\begin{array}{r}63.4 \\
5\end{array}$ & $\begin{array}{r}57.3 \\
3\end{array}$ & 314 & 29 & 343 \\
\hline 3 & $\begin{array}{l}600- \\
420 \\
0\end{array}$ & 6: SB 101 End & 0.49 & 0.29 & $\begin{array}{r}62.5 \\
7\end{array}$ & $\begin{array}{r}55.9 \\
5\end{array}$ & $\begin{array}{r}166 \\
6\end{array}$ & 149 & 1815 \\
\hline 3 & \begin{tabular}{|l|}
$600-$ \\
420 \\
0 \\
\end{tabular} & 7: NB Truck Lane & 0.05 & -0.05 & $\begin{array}{r}60.7 \\
8 \\
\end{array}$ & 21.6 & $\begin{array}{r}231 \\
6 \\
\end{array}$ & 249 & 2565 \\
\hline 3 & \begin{tabular}{|l|}
$600-$ \\
420 \\
0
\end{tabular} & 8: SB Truck Lane & 0.06 & 0 & $\begin{array}{r}63.1 \\
6\end{array}$ & $\begin{array}{r}30.3 \\
8\end{array}$ & $\begin{array}{r}197 \\
7\end{array}$ & 199 & 2176 \\
\hline 4 & $\begin{array}{l}600- \\
420 \\
0\end{array}$ & 1: NB 101 After Monterey & 0.26 & 0.41 & $\begin{array}{r}61.1 \\
9\end{array}$ & $\begin{array}{r}52.5 \\
4\end{array}$ & $\begin{array}{r}228 \\
6\end{array}$ & 203 & 2489 \\
\hline 4 & $\begin{array}{l}600- \\
420 \\
0\end{array}$ & 2: JCT 58 NB Off Ramp & 1.07 & 0.26 & $\begin{array}{r}63.3 \\
3 \\
\end{array}$ & $\begin{array}{r}57.3 \\
8 \\
\end{array}$ & 178 & 18 & 196 \\
\hline 4 & $\begin{array}{l}600- \\
420 \\
0\end{array}$ & 3: NB 101 End & 0.45 & 0.15 & $\begin{array}{r}60.0 \\
8\end{array}$ & 55.9 & $\begin{array}{r}212 \\
5\end{array}$ & 192 & 2317 \\
\hline 4 & $\begin{array}{l}600- \\
420 \\
0\end{array}$ & 4: SB 101 After JCT 58 & 0.01 & -0.38 & $\begin{array}{r}63.4 \\
2\end{array}$ & $\begin{array}{r}56.0 \\
1\end{array}$ & $\begin{array}{r}187 \\
5\end{array}$ & 170 & 2045 \\
\hline 4 & $\begin{array}{l}600- \\
420 \\
0\end{array}$ & 5: Monterey SB Off Ramp & 0.85 & 0.27 & $\begin{array}{r}63.5 \\
2\end{array}$ & $\begin{array}{r}56.2 \\
3\end{array}$ & 324 & 19 & 343 \\
\hline 4 & $\begin{array}{l}600- \\
420 \\
0\end{array}$ & 6: SB 101 End & 0.42 & 0.4 & $\begin{array}{r}62.7 \\
8 \\
\end{array}$ & $\begin{array}{r}55.6 \\
7 \\
\end{array}$ & $\begin{array}{r}159 \\
9 \\
\end{array}$ & 139 & 1738 \\
\hline 4 & \begin{tabular}{|l|}
$600-$ \\
420 \\
0
\end{tabular} & 7: NB Truck Lane & -0.04 & 0.02 & $\begin{array}{r}61.1 \\
7\end{array}$ & $\begin{array}{r}21.5 \\
3\end{array}$ & $\begin{array}{r}233 \\
3\end{array}$ & 212 & 2545 \\
\hline
\end{tabular}




\begin{tabular}{|c|c|c|c|c|c|c|c|c|c|}
\hline 4 & \begin{tabular}{l|l}
$600-$ \\
420 \\
4
\end{tabular} & 8: SB Truck Lane & 0.01 & -0.08 & $\begin{array}{r}63.6 \\
1\end{array}$ & $\begin{array}{r}29.9 \\
1\end{array}$ & $\begin{array}{r}188 \\
9 \\
\end{array}$ & 177 & 2066 \\
\hline 5 & \begin{tabular}{|l|l}
$600-$ \\
420 \\
5
\end{tabular} & 1: NB 101 After Monterey & 0.32 & 0.56 & 61 & $\begin{array}{r}51.3 \\
9\end{array}$ & $\begin{array}{r}226 \\
1\end{array}$ & 214 & 2475 \\
\hline 5 & \begin{tabular}{l|l}
$600-$ \\
420 \\
5
\end{tabular} & 2: JCT 58 NB Off Ramp & 0.69 & 0.35 & $\begin{array}{r}63.4 \\
6\end{array}$ & $\begin{array}{r}56.9 \\
9\end{array}$ & 170 & 17 & 187 \\
\hline 5 & \begin{tabular}{|l|l}
$600-$ \\
420 \\
5
\end{tabular} & 3: NB 101 End & 0.37 & 0.18 & $\begin{array}{r}60.8 \\
1\end{array}$ & $\begin{array}{r}55.0 \\
6\end{array}$ & $\begin{array}{r}214 \\
5\end{array}$ & 192 & 2337 \\
\hline 5 & \begin{tabular}{l|l}
$600-$ \\
420 \\
5
\end{tabular} & 4: SB 101 After JCT 58 & -0.05 & -0.42 & $\begin{array}{r}63.1 \\
3\end{array}$ & $\begin{array}{r}55.7 \\
5\end{array}$ & $\begin{array}{r}190 \\
4\end{array}$ & 187 & 2091 \\
\hline 5 & \begin{tabular}{l|l}
$600-$ \\
420 \\
5
\end{tabular} & 5: Monterey SB Off Ramp & 0.85 & 0.15 & $\begin{array}{r}63.9 \\
1\end{array}$ & $\begin{array}{r}56.1 \\
7\end{array}$ & 323 & 24 & 347 \\
\hline 5 & \begin{tabular}{|l|l}
$600-$ \\
420 \\
0
\end{tabular} & 6: SB 101 End & 0.58 & 0.36 & $\begin{array}{r}62.0 \\
8 \\
\end{array}$ & $\begin{array}{r}55.6 \\
6 \\
\end{array}$ & $\begin{array}{r}159 \\
0 \\
\end{array}$ & 159 & 1749 \\
\hline 5 & \begin{tabular}{l|l}
$600-$ \\
420 \\
5
\end{tabular} & 7: NB Truck Lane & -0.03 & -0.04 & $\begin{array}{r}61.2 \\
5\end{array}$ & 21.7 & $\begin{array}{r}228 \\
9\end{array}$ & 211 & 2500 \\
\hline 5 & \begin{tabular}{|l|l}
$600-$ \\
420 \\
5
\end{tabular} & 8: SB Truck Lane & -0.02 & -0.02 & $\begin{array}{r}63.2 \\
4\end{array}$ & $\begin{array}{r}30.8 \\
5\end{array}$ & $\begin{array}{r}192 \\
2\end{array}$ & 183 & 2105 \\
\hline AVG & $\begin{array}{l}600- \\
420 \\
0\end{array}$ & 1: NB 101 After Monterey & 0.3 & 0.46 & $\begin{array}{r}61.1 \\
2\end{array}$ & $\begin{array}{r}52.0 \\
6\end{array}$ & $\begin{array}{r}227 \\
7\end{array}$ & 223 & 2500 \\
\hline AVG & $\begin{array}{l}600- \\
420 \\
0 \\
\end{array}$ & 2: JCT 58 NB Off Ramp & 0.87 & 0.35 & $\begin{array}{r}63.3 \\
7 \\
\end{array}$ & $\begin{array}{r}56.8 \\
3 \\
\end{array}$ & 164 & 18 & 182 \\
\hline AVG & $\begin{array}{l}600- \\
420 \\
0\end{array}$ & 3: NB 101 End & 0.43 & 0.15 & $\begin{array}{r}60.1 \\
9\end{array}$ & $\begin{array}{r}54.8 \\
1\end{array}$ & $\begin{array}{r}212 \\
8\end{array}$ & 203 & 2330 \\
\hline
\end{tabular}




\begin{tabular}{|c|c|c|c|c|c|c|c|c|c|}
\hline AVG & $\begin{array}{l}600- \\
420 \\
0\end{array}$ & 4: SB 101 After JCT 58 & -0.01 & -0.38 & 63.2 & $\begin{array}{r}55.6 \\
1\end{array}$ & $\begin{array}{r}190 \\
9\end{array}$ & 189 & 2098 \\
\hline AVG & $\begin{array}{l}600- \\
420 \\
0\end{array}$ & 5: Monterey SB Off Ramp & 0.83 & 0.21 & $\begin{array}{r}63.6 \\
9\end{array}$ & $\begin{array}{r}56.7 \\
6\end{array}$ & 311 & 24 & 335 \\
\hline AVG & $\begin{array}{l}600- \\
420 \\
0\end{array}$ & 6: SB 101 End & 0.49 & 0.32 & $\begin{array}{r}62.4 \\
4\end{array}$ & 55.8 & $\begin{array}{r}162 \\
5\end{array}$ & 154 & 1779 \\
\hline AVG & $\begin{array}{l}600- \\
420 \\
0\end{array}$ & 7: NB Truck Lane & -0.01 & 0 & $\begin{array}{r}60.9 \\
6\end{array}$ & $\begin{array}{r}21.3 \\
9\end{array}$ & $\begin{array}{r}230 \\
4\end{array}$ & 226 & 2530 \\
\hline AVG & $\begin{array}{l}600- \\
420 \\
0\end{array}$ & 8: SB Truck Lane & 0.01 & -0.05 & $\begin{array}{r}63.2 \\
7\end{array}$ & $\begin{array}{r}30.3 \\
5\end{array}$ & $\begin{array}{r}192 \\
8\end{array}$ & 190 & 2118 \\
\hline STDDEV & $\begin{array}{l}600- \\
420 \\
0\end{array}$ & 1: NB 101 After Monterey & 0.03 & 0.06 & 0.33 & 0.82 & 15 & 16 & 22 \\
\hline STDDEV & $\begin{array}{l}600- \\
420 \\
0\end{array}$ & 2: JCT 58 NB Off Ramp & 0.18 & 0.09 & 0.29 & 0.36 & 11 & 6 & 10 \\
\hline STDDEV & $\begin{array}{l}600- \\
420 \\
0\end{array}$ & 3: NB 101 End & 0.08 & 0.09 & 0.55 & 0.87 & 23 & 14 & 30 \\
\hline STDDEV & $\begin{array}{l}600- \\
420 \\
0\end{array}$ & 4: SB 101 After JCT 58 & 0.03 & 0.05 & 0.17 & 0.55 & 48 & 13 & 58 \\
\hline STDDEV & $\begin{array}{l}600- \\
420 \\
0\end{array}$ & 5: Monterey SB Off Ramp & 0.06 & 0.05 & 0.21 & 0.56 & 16 & 4 & 17 \\
\hline STDDEV & $\begin{array}{l}600- \\
420 \\
0\end{array}$ & 6: SB 101 End & 0.07 & 0.06 & 0.28 & 0.34 & 43 & 13 & 51 \\
\hline STDDEV & $\begin{array}{l}600- \\
420 \\
0\end{array}$ & 7: NB Truck Lane & 0.04 & 0.04 & 0.35 & 0.34 & 20 & 17 & 26 \\
\hline
\end{tabular}




\begin{tabular}{|c|c|c|c|c|c|c|c|c|c|}
\hline STDDEV & $\begin{array}{l}600- \\
420 \\
0\end{array}$ & 8: SB Truck Lane & 0.03 & 0.05 & 0.2 & 0.34 & 48 & 13 & 60 \\
\hline MIN & $\begin{array}{l}600- \\
420 \\
0\end{array}$ & 1: NB 101 After Monterey & 0.26 & 0.41 & $\begin{array}{r}60.6 \\
4\end{array}$ & $\begin{array}{r}51.3 \\
7\end{array}$ & $\begin{array}{r}226 \\
1\end{array}$ & 203 & 2475 \\
\hline MIN & $\begin{array}{l}600- \\
420 \\
0\end{array}$ & 2: JCT 58 NB Off Ramp & 0.68 & 0.26 & $\begin{array}{r}63.0 \\
5\end{array}$ & $\begin{array}{r}56.4 \\
9\end{array}$ & 149 & 12 & 170 \\
\hline MIN & $\begin{array}{l}600- \\
420 \\
0\end{array}$ & 3: NB 101 End & 0.33 & 0.01 & $\begin{array}{r}59.6 \\
7\end{array}$ & $\begin{array}{r}53.9 \\
1\end{array}$ & $\begin{array}{r}209 \\
3 \\
\end{array}$ & 192 & 2287 \\
\hline MIN & $\begin{array}{l}600- \\
420 \\
0\end{array}$ & 4: SB 101 After JCT 58 & -0.05 & -0.42 & $\begin{array}{r}62.9 \\
8\end{array}$ & $\begin{array}{r}54.6 \\
8\end{array}$ & $\begin{array}{r}185 \\
5\end{array}$ & 170 & 2040 \\
\hline MIN & $\begin{array}{l}600- \\
420 \\
0\end{array}$ & 5: Monterey SB Off Ramp & 0.73 & 0.15 & $\begin{array}{r}63.4 \\
5\end{array}$ & $\begin{array}{r}56.1 \\
7\end{array}$ & 284 & 19 & 305 \\
\hline MIN & $\begin{array}{l}600- \\
420 \\
0\end{array}$ & 6: SB 101 End & 0.41 & 0.26 & $\begin{array}{r}62.0 \\
8\end{array}$ & 55.4 & $\begin{array}{r}159 \\
0\end{array}$ & 139 & 1738 \\
\hline MIN & $\begin{array}{l}600- \\
420 \\
0\end{array}$ & 7: NB Truck Lane & -0.04 & -0.05 & $\begin{array}{r}60.4 \\
4\end{array}$ & $\begin{array}{r}20.8 \\
7\end{array}$ & $\begin{array}{r}228 \\
4\end{array}$ & 211 & 2500 \\
\hline MIN & $\begin{array}{l}600- \\
420 \\
0\end{array}$ & 8: SB Truck Lane & -0.02 & -0.11 & $\begin{array}{r}63.0 \\
8\end{array}$ & $\begin{array}{r}29.9 \\
1\end{array}$ & $\begin{array}{r}187 \\
5\end{array}$ & 177 & 2057 \\
\hline MAX & $\begin{array}{l}600- \\
420 \\
0\end{array}$ & 1: NB 101 After Monterey & 0.33 & 0.56 & 61.5 & $\begin{array}{r}53.2 \\
6\end{array}$ & $\begin{array}{r}229 \\
9\end{array}$ & 243 & 2532 \\
\hline MAX & $\begin{array}{l}600- \\
420 \\
0\end{array}$ & 2: JCT 58 NB Off Ramp & 1.07 & 0.51 & 63.8 & $\begin{array}{r}57.3 \\
8\end{array}$ & 178 & 28 & 196 \\
\hline MAX & $\begin{array}{l}600- \\
420 \\
0\end{array}$ & 3: NB 101 End & 0.53 & 0.25 & $\begin{array}{r}60.8 \\
1\end{array}$ & 55.9 & $\begin{array}{r}215 \\
3\end{array}$ & 221 & 2367 \\
\hline
\end{tabular}




\begin{tabular}{|c|c|c|c|c|c|c|c|c|c|}
\hline MAX & $\begin{array}{l}600- \\
420 \\
0\end{array}$ & 4: SB 101 After JCT 58 & 0.03 & -0.31 & $\begin{array}{r}63.4 \\
2 \\
\end{array}$ & $\begin{array}{r}56.0 \\
3 \\
\end{array}$ & $\begin{array}{r}197 \\
2 \\
\end{array}$ & 201 & 2172 \\
\hline MAX & $\begin{array}{l}600- \\
420 \\
0\end{array}$ & 5: Monterey SB Off Ramp & 0.88 & 0.27 & $\begin{array}{r}63.9 \\
1 \\
\end{array}$ & $\begin{array}{r}57.3 \\
3 \\
\end{array}$ & 324 & 29 & 347 \\
\hline MAX & $\begin{array}{l}\text { 600- } \\
420 \\
0\end{array}$ & 6: SB 101 End & 0.58 & 0.4 & $\begin{array}{r}62.7 \\
8\end{array}$ & 56.3 & $\begin{array}{r}167 \\
8\end{array}$ & 173 & 1851 \\
\hline MAX & $\begin{array}{l}\text { 600- } \\
420 \\
0\end{array}$ & 7: NB Truck Lane & 0.05 & 0.04 & $\begin{array}{r}61.2 \\
5 \\
\end{array}$ & 21.7 & $\begin{array}{r}233 \\
3 \\
\end{array}$ & 249 & 2565 \\
\hline MAX & $\begin{array}{l}600- \\
420 \\
0\end{array}$ & 8: SB Truck Lane & 0.06 & 0 & $\begin{array}{r}63.6 \\
1\end{array}$ & $\begin{array}{r}30.8 \\
5\end{array}$ & $\begin{array}{r}197 \\
8\end{array}$ & 207 & 2185 \\
\hline
\end{tabular}

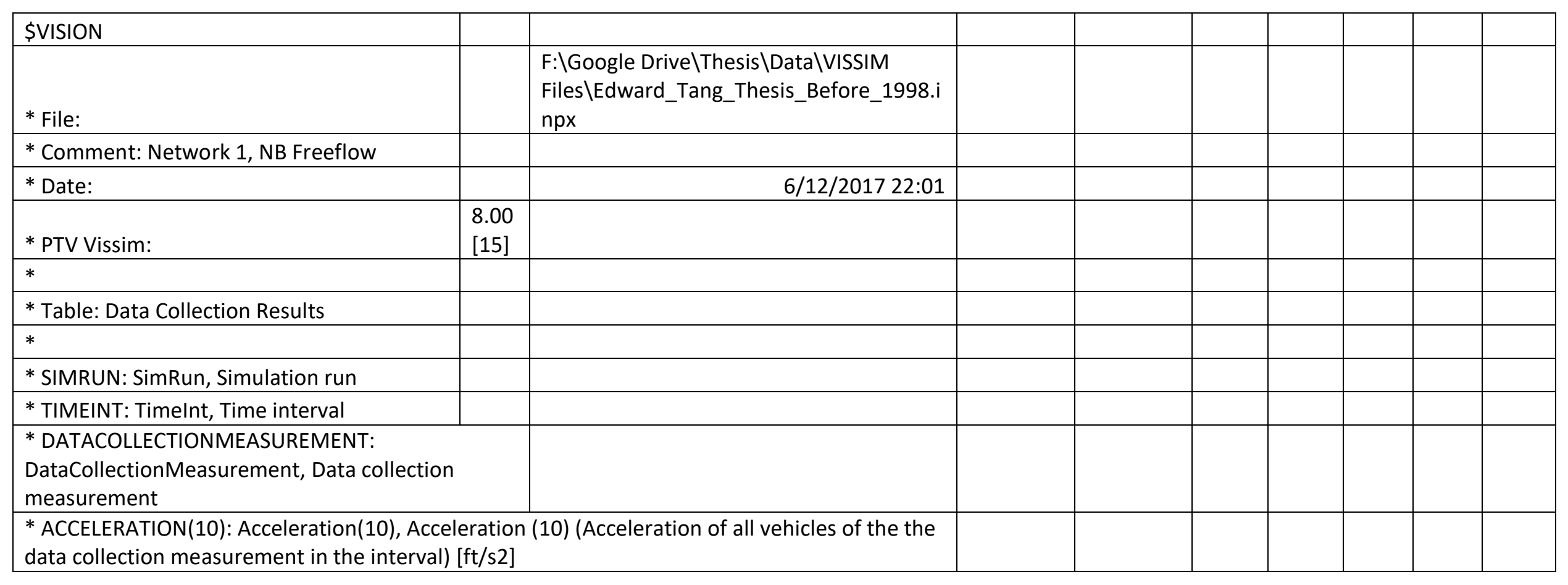


* ACCELERATION(20): Acceleration(20), Acceleration (20) (Acceleration of all vehicles of the the data collection measurement in the interval) [ft/s2]

* SPEED(20): Speed(20), Speed (20) (Speed of all vehicles of the the data collection

measurement in the interval) $[\mathrm{mph}]$

* SPEED(10): Speed(10), Speed (10) (Speed of all vehicles of the the data collection

measurement in the interval) [mph]

* VEHS(10): Vehs(10), Vehicles (10) (Count of vehicles of the the data collection measurement

in the interval)

* VEHS(20): Vehs(20), Vehicles (20) (Count of vehicles of the the data collection measurement

in the interval)

* VEHS(ALL): Vehs(All), Vehicles (All) (Count of vehicles of the the data collection measurement in the interval)

\begin{tabular}{|c|c|c|c|c|c|c|c|c|c|}
\hline * & & & & & & & & & \\
\hline * SimRun & $\begin{array}{l}\text { Tim } \\
\text { elnt }\end{array}$ & DataCollectionMeasurement & $\begin{array}{l}\text { Accelerat } \\
\text { ion(10) }\end{array}$ & $\begin{array}{l}\text { Accelerat } \\
\text { ion }(20)\end{array}$ & $\begin{array}{l}\text { Spee } \\
d(20)\end{array}$ & $\begin{array}{l}\text { Spee } \\
d(10)\end{array}$ & $\begin{array}{l}\text { Veh } \\
\text { s(10 } \\
)\end{array}$ & $\begin{array}{l}\text { Veh } \\
s(20 \\
)\end{array}$ & $\begin{array}{l}\text { Vehs } \\
\text { (All) }\end{array}$ \\
\hline \multicolumn{10}{|l|}{ * } \\
\hline $\begin{array}{l}\text { \$DATACOLLECTIONMEASUREMENTEVALUA } \\
\text { TION:SIMRUN }\end{array}$ & $\begin{array}{l}\text { TIM } \\
\text { EINT }\end{array}$ & DATACOLLECTIONMEASUREMENT & $\begin{array}{l}\text { ACCELER } \\
\text { ATION(10 } \\
\text { ) }\end{array}$ & $\begin{array}{l}\text { ACCELER } \\
\text { ATION }(20 \\
\text { ) }\end{array}$ & $\begin{array}{l}\text { SPEE } \\
D(20 \\
)\end{array}$ & $\begin{array}{l}\text { SPEE } \\
D(10 \\
)\end{array}$ & $\begin{array}{l}\text { VEH } \\
\mathrm{S}(10 \\
)\end{array}$ & $\begin{array}{l}\text { VEH } \\
\text { S(20 } \\
)\end{array}$ & $\begin{array}{l}\text { VEH } \\
S(A L \\
L)\end{array}$ \\
\hline 1 & $\begin{array}{l}600- \\
420 \\
0\end{array}$ & 1: NB 101 After Monterey & 0.32 & 0.48 & $\begin{array}{r}52.2 \\
3\end{array}$ & $\begin{array}{r}60.0 \\
7\end{array}$ & $\begin{array}{r}266 \\
8\end{array}$ & 242 & 2910 \\
\hline 1 & $\begin{array}{l}600- \\
420 \\
0\end{array}$ & 2: JCT 58 NB Off Ramp & 0.89 & 0.11 & $\begin{array}{r}56.2 \\
3\end{array}$ & $\begin{array}{r}63.3 \\
9\end{array}$ & 170 & 14 & 184 \\
\hline 1 & $\begin{array}{l}600- \\
420 \\
0\end{array}$ & 3: NB 101 End & 0.41 & 0.18 & $\begin{array}{r}54.7 \\
1\end{array}$ & $\begin{array}{r}60.4 \\
9\end{array}$ & $\begin{array}{r}214 \\
9\end{array}$ & 196 & 2345 \\
\hline 1 & $\begin{array}{l}600- \\
420 \\
0\end{array}$ & 4: SB 101 After JCT 58 & -0.03 & -0.41 & $\begin{array}{r}56.6 \\
9\end{array}$ & $\begin{array}{r}63.5 \\
8\end{array}$ & $\begin{array}{r}170 \\
3\end{array}$ & 161 & 1864 \\
\hline 1 & $\begin{array}{l}600- \\
420 \\
0\end{array}$ & 5: Monterey SB Off Ramp & 0.91 & 0.31 & $\begin{array}{r}57.1 \\
5\end{array}$ & $\begin{array}{r}63.5 \\
2\end{array}$ & 312 & 28 & 340 \\
\hline
\end{tabular}




\begin{tabular}{|c|c|c|c|c|c|c|c|c|c|}
\hline 1 & \begin{tabular}{|l|}
$600-$ \\
420 \\
0 \\
\end{tabular} & 6: SB 101 End & 0.37 & 0.35 & $\begin{array}{r}56.2 \\
6 \\
\end{array}$ & $\begin{array}{r}62.9 \\
5 \\
\end{array}$ & $\begin{array}{r}138 \\
1 \\
\end{array}$ & 137 & 1518 \\
\hline 1 & \begin{tabular}{|l|}
$600-$ \\
420 \\
0
\end{tabular} & 7: NB Truck Lane & 0.02 & 0.14 & $\begin{array}{r}21.1 \\
3\end{array}$ & $\begin{array}{r}46.0 \\
8\end{array}$ & $\begin{array}{r}250 \\
2\end{array}$ & 232 & 2734 \\
\hline 1 & \begin{tabular}{|l|}
$600-$ \\
420 \\
0 \\
\end{tabular} & 8: SB Truck Lane & -0.04 & 0.2 & $\begin{array}{r}30.8 \\
5 \\
\end{array}$ & $\begin{array}{r}61.2 \\
3 \\
\end{array}$ & $\begin{array}{r}167 \\
9 \\
\end{array}$ & 166 & 1845 \\
\hline 2 & \begin{tabular}{|l|}
$600-$ \\
420 \\
0 \\
\end{tabular} & 1: NB 101 After Monterey & 0.21 & 0.33 & $\begin{array}{r}51.2 \\
8\end{array}$ & $\begin{array}{r}60.0 \\
1\end{array}$ & $\begin{array}{r}266 \\
9 \\
\end{array}$ & 258 & 2927 \\
\hline 2 & \begin{tabular}{|l|}
$600-$ \\
420 \\
0
\end{tabular} & 2: JCT 58 NB Off Ramp & 1.02 & 0.38 & $\begin{array}{r}56.7 \\
5\end{array}$ & $\begin{array}{r}63.1 \\
9\end{array}$ & 182 & 20 & 202 \\
\hline 2 & \begin{tabular}{|l|}
$600-$ \\
420 \\
0
\end{tabular} & 3: NB 101 End & 0.58 & 0.32 & $\begin{array}{r}52.2 \\
8\end{array}$ & $\begin{array}{r}59.5 \\
5\end{array}$ & $\begin{array}{r}223 \\
7\end{array}$ & 197 & 2434 \\
\hline 2 & \begin{tabular}{|l|}
$600-$ \\
420 \\
0 \\
\end{tabular} & 4: SB 101 After JCT 58 & 0.04 & -0.35 & $\begin{array}{r}55.8 \\
4 \\
\end{array}$ & $\begin{array}{r}63.5 \\
7 \\
\end{array}$ & $\begin{array}{r}158 \\
2 \\
\end{array}$ & 139 & 1721 \\
\hline 2 & \begin{tabular}{|l|}
$600-$ \\
420 \\
0 \\
\end{tabular} & 5: Monterey SB Off Ramp & 0.86 & 0.32 & $\begin{array}{r}55.4 \\
9 \\
\end{array}$ & $\begin{array}{r}63.0 \\
3 \\
\end{array}$ & 265 & 21 & 286 \\
\hline 2 & \begin{tabular}{|l|}
$600-$ \\
420 \\
0 \\
\end{tabular} & 6: SB 101 End & 0.34 & 0.37 & $\begin{array}{r}56.0 \\
2 \\
\end{array}$ & $\begin{array}{r}63.2 \\
1 \\
\end{array}$ & $\begin{array}{r}128 \\
8 \\
\end{array}$ & 102 & 1390 \\
\hline 2 & \begin{tabular}{|l|}
$600-$ \\
420 \\
0 \\
\end{tabular} & 7: NB Truck Lane & 0.02 & -0.1 & $\begin{array}{r}21.0 \\
9\end{array}$ & $\begin{array}{r}45.6 \\
8\end{array}$ & $\begin{array}{r}254 \\
1\end{array}$ & 247 & 2788 \\
\hline 2 & \begin{tabular}{|l|}
$600-$ \\
420 \\
0 \\
\end{tabular} & 8: SB Truck Lane & -0.01 & 0.22 & 30.1 & $\begin{array}{r}62.2 \\
3 \\
\end{array}$ & $\begin{array}{r}154 \\
9 \\
\end{array}$ & 129 & 1678 \\
\hline 3 & \begin{tabular}{|l|}
$600-$ \\
420 \\
0 \\
\end{tabular} & 1: NB 101 After Monterey & 0.22 & 0.59 & $\begin{array}{r}49.9 \\
9 \\
\end{array}$ & $\begin{array}{r}59.5 \\
7 \\
\end{array}$ & $\begin{array}{r}265 \\
3 \\
\end{array}$ & 285 & 2938 \\
\hline
\end{tabular}




\begin{tabular}{|c|c|c|c|c|c|c|c|c|c|}
\hline 3 & $\begin{array}{l}600- \\
420 \\
0\end{array}$ & 2: JCT 58 NB Off Ramp & 0.71 & 0.3 & $\begin{array}{r}57.0 \\
4 \\
\end{array}$ & $\begin{array}{r}64.0 \\
2 \\
\end{array}$ & 194 & 16 & 210 \\
\hline 3 & $\begin{array}{l}600- \\
420 \\
0\end{array}$ & 3: NB 101 End & 0.27 & 0.16 & $\begin{array}{r}54.9 \\
5\end{array}$ & $\begin{array}{r}61.1 \\
6\end{array}$ & $\begin{array}{r}212 \\
9\end{array}$ & 207 & 2336 \\
\hline 3 & $\begin{array}{l}600- \\
420 \\
0\end{array}$ & 4: SB 101 After JCT 58 & 0.02 & -0.31 & $\begin{array}{r}55.9 \\
4\end{array}$ & $\begin{array}{r}63.5 \\
9\end{array}$ & $\begin{array}{r}167 \\
0\end{array}$ & 162 & 1832 \\
\hline 3 & $\begin{array}{l}600- \\
420 \\
0\end{array}$ & 5: Monterey SB Off Ramp & 0.77 & 0.44 & $\begin{array}{r}57.5 \\
2\end{array}$ & $\begin{array}{r}63.8 \\
4\end{array}$ & 320 & 23 & 343 \\
\hline 3 & $\begin{array}{l}600- \\
420 \\
0\end{array}$ & 6: SB 101 End & 0.42 & 0.41 & $\begin{array}{r}55.5 \\
7\end{array}$ & $\begin{array}{r}63.2 \\
7\end{array}$ & $\begin{array}{r}133 \\
4\end{array}$ & 114 & 1448 \\
\hline 3 & $\begin{array}{l}600- \\
420 \\
0\end{array}$ & 7: NB Truck Lane & -0.11 & -0.06 & $\begin{array}{r}20.8 \\
7\end{array}$ & $\begin{array}{r}46.3 \\
5\end{array}$ & $\begin{array}{r}253 \\
5\end{array}$ & 275 & 2810 \\
\hline 3 & $\begin{array}{l}600- \\
420 \\
0\end{array}$ & 8: SB Truck Lane & -0.08 & 0.14 & $\begin{array}{r}30.6 \\
2 \\
\end{array}$ & $\begin{array}{r}61.7 \\
7 \\
\end{array}$ & $\begin{array}{r}165 \\
5 \\
\end{array}$ & 153 & 1808 \\
\hline 4 & $\begin{array}{l}600- \\
420 \\
0\end{array}$ & 1: NB 101 After Monterey & 0.31 & 0.4 & $\begin{array}{r}51.8 \\
1 \\
\end{array}$ & $\begin{array}{r}60.0 \\
7 \\
\end{array}$ & $\begin{array}{r}267 \\
4 \\
\end{array}$ & 249 & 2923 \\
\hline 4 & $\begin{array}{l}600- \\
420 \\
0\end{array}$ & 2: JCT 58 NB Off Ramp & 0.89 & 0.24 & $\begin{array}{r}58.6 \\
9\end{array}$ & $\begin{array}{r}63.9 \\
9\end{array}$ & 155 & 20 & 175 \\
\hline 4 & $\begin{array}{l}600- \\
420 \\
0\end{array}$ & 3: NB 101 End & 0.3 & -0.03 & $\begin{array}{r}55.7 \\
8\end{array}$ & $\begin{array}{r}60.7 \\
3\end{array}$ & $\begin{array}{r}220 \\
5 \\
\end{array}$ & 181 & 2386 \\
\hline 4 & $\begin{array}{l}600- \\
420 \\
0\end{array}$ & 4: SB 101 After JCT 58 & 0.03 & -0.37 & $\begin{array}{r}56.0 \\
4\end{array}$ & $\begin{array}{r}63.9 \\
5\end{array}$ & $\begin{array}{r}158 \\
4 \\
\end{array}$ & 129 & 1713 \\
\hline 4 & $\begin{array}{l}600- \\
420 \\
0\end{array}$ & 5: Monterey SB Off Ramp & 0.87 & 0.16 & 56.8 & $\begin{array}{r}63.7 \\
4\end{array}$ & 302 & 19 & 321 \\
\hline
\end{tabular}




\begin{tabular}{|c|c|c|c|c|c|c|c|c|c|c|}
\hline & 4 & $\begin{array}{l}600- \\
420 \\
0\end{array}$ & 6: SB 101 End & 0.32 & 0.43 & $\begin{array}{r}56.0 \\
3\end{array}$ & $\begin{array}{r}63.3 \\
2\end{array}$ & $\begin{array}{r}128 \\
3\end{array}$ & 106 & 1389 \\
\hline & 4 & $\begin{array}{l}600- \\
420 \\
0\end{array}$ & 7: NB Truck Lane & 0.04 & -0.02 & $\begin{array}{r}21.1 \\
8\end{array}$ & $\begin{array}{r}46.5 \\
8\end{array}$ & $\begin{array}{r}253 \\
5\end{array}$ & 238 & 2773 \\
\hline & 4 & $\begin{array}{l}600- \\
420 \\
0\end{array}$ & 8: SB Truck Lane & -0.07 & 0.09 & $\begin{array}{r}30.5 \\
9\end{array}$ & $\begin{array}{r}62.1 \\
7\end{array}$ & $\begin{array}{r}158 \\
6\end{array}$ & 128 & 1714 \\
\hline & 5 & $\begin{array}{l}600- \\
420 \\
0\end{array}$ & 1: NB 101 After Monterey & 0.37 & 0.49 & $\begin{array}{r}50.8 \\
7\end{array}$ & $\begin{array}{r}59.6 \\
2\end{array}$ & $\begin{array}{r}265 \\
9\end{array}$ & 236 & 2895 \\
\hline & 5 & $\begin{array}{l}600- \\
420 \\
0\end{array}$ & 2: JCT 58 NB Off Ramp & 0.97 & 0.25 & $\begin{array}{r}55.9 \\
4\end{array}$ & $\begin{array}{r}63.3 \\
6\end{array}$ & 185 & 24 & 209 \\
\hline & 5 & $\begin{array}{l}600- \\
420 \\
0\end{array}$ & 4: SB 101 After JCT 58 & -0.04 & -0.41 & $\begin{array}{r}56.3 \\
4\end{array}$ & $\begin{array}{r}63.4 \\
2\end{array}$ & $\begin{array}{r}164 \\
7\end{array}$ & 150 & 1797 \\
\hline & 5 & $\begin{array}{l}600- \\
420 \\
0\end{array}$ & 5: Monterey SB Off Ramp & 0.8 & 0.37 & $\begin{array}{r}55.7 \\
5\end{array}$ & $\begin{array}{r}63.8 \\
8 \\
\end{array}$ & 303 & 24 & 327 \\
\hline & 5 & $\begin{array}{l}600- \\
420 \\
0\end{array}$ & 6: SB 101 End & 0.33 & 0.31 & $\begin{array}{r}56.4 \\
2\end{array}$ & $\begin{array}{r}63.2 \\
9\end{array}$ & $\begin{array}{r}129 \\
0\end{array}$ & 115 & 1405 \\
\hline & 5 & $\begin{array}{l}600- \\
420 \\
0\end{array}$ & 7: NB Truck Lane & 0.02 & -0.04 & $\begin{array}{r}21.8 \\
7\end{array}$ & $\begin{array}{r}46.8 \\
8 \\
\end{array}$ & $\begin{array}{r}252 \\
6 \\
\end{array}$ & 220 & 2746 \\
\hline AVG & & $\begin{array}{l}600- \\
420 \\
0\end{array}$ & 1: NB 101 After Monterey & 0.29 & 0.46 & $\begin{array}{r}51.2 \\
4\end{array}$ & $\begin{array}{r}59.8 \\
7\end{array}$ & $\begin{array}{r}266 \\
5\end{array}$ & 254 & 2919 \\
\hline
\end{tabular}




\begin{tabular}{|c|c|c|c|c|c|c|c|c|c|}
\hline AVG & $\begin{array}{l}600- \\
420 \\
0\end{array}$ & 2: JCT 58 NB Off Ramp & 0.9 & 0.26 & $\begin{array}{r}56.9 \\
3\end{array}$ & $\begin{array}{r}63.5 \\
9\end{array}$ & 177 & 19 & 196 \\
\hline AVG & $\begin{array}{l}600- \\
420 \\
0\end{array}$ & 3: NB 101 End & 0.43 & 0.16 & $\begin{array}{r}54.3 \\
6\end{array}$ & 60.4 & $\begin{array}{r}219 \\
1\end{array}$ & 193 & 2384 \\
\hline AVG & $\begin{array}{l}600- \\
420 \\
0\end{array}$ & 4: SB 101 After JCT 58 & 0 & -0.37 & $\begin{array}{r}56.1 \\
7\end{array}$ & $\begin{array}{r}63.6 \\
2\end{array}$ & $\begin{array}{r}163 \\
7\end{array}$ & 148 & 1785 \\
\hline AVG & $\begin{array}{l}600- \\
420 \\
0\end{array}$ & 5: Monterey SB Off Ramp & 0.84 & 0.32 & $\begin{array}{r}56.5 \\
4\end{array}$ & 63.6 & 300 & 23 & 323 \\
\hline AVG & $\begin{array}{l}\text { 600- } \\
420 \\
0\end{array}$ & 6: SB 101 End & 0.36 & 0.37 & $\begin{array}{r}56.0 \\
6\end{array}$ & $\begin{array}{r}63.2 \\
1\end{array}$ & $\begin{array}{r}131 \\
5\end{array}$ & 115 & 1430 \\
\hline AVG & $\begin{array}{l}600- \\
420 \\
0\end{array}$ & 7: NB Truck Lane & 0 & -0.02 & $\begin{array}{r}21.2 \\
3\end{array}$ & $\begin{array}{r}46.3 \\
1\end{array}$ & $\begin{array}{r}252 \\
8\end{array}$ & 242 & 2770 \\
\hline AVG & $\begin{array}{l}600- \\
420 \\
0\end{array}$ & 8: SB Truck Lane & -0.04 & 0.17 & $\begin{array}{r}30.5 \\
8\end{array}$ & $\begin{array}{r}61.7 \\
5\end{array}$ & $\begin{array}{r}161 \\
7\end{array}$ & 144 & 1761 \\
\hline STDDEV & $\begin{array}{l}600- \\
420 \\
0\end{array}$ & 1: NB 101 After Monterey & 0.07 & 0.1 & 0.87 & 0.25 & 8 & 19 & 17 \\
\hline STDDEV & $\begin{array}{l}600- \\
420 \\
0\end{array}$ & 2: JCT 58 NB Off Ramp & 0.12 & 0.1 & 1.07 & 0.38 & 15 & 4 & 16 \\
\hline STDDEV & $\begin{array}{l}600- \\
420 \\
0\end{array}$ & 3: NB 101 End & 0.16 & 0.12 & 1.31 & 0.61 & 49 & 11 & 43 \\
\hline STDDEV & $\begin{array}{l}600- \\
420 \\
0\end{array}$ & 4: SB 101 After JCT 58 & 0.04 & 0.04 & 0.34 & 0.2 & 53 & 14 & 67 \\
\hline STDDEV & $\begin{array}{l}600- \\
420 \\
0\end{array}$ & 5: Monterey SB Off Ramp & 0.06 & 0.11 & 0.88 & 0.35 & 21 & 3 & 23 \\
\hline
\end{tabular}




\begin{tabular}{|c|c|c|c|c|c|c|c|c|c|}
\hline STDDEV & $\begin{array}{l}600- \\
420 \\
0 \\
\end{array}$ & 6: SB 101 End & 0.04 & 0.05 & 0.32 & 0.15 & 42 & 14 & 55 \\
\hline STDDEV & $\begin{array}{l}600- \\
420 \\
0\end{array}$ & 7: NB Truck Lane & 0.06 & 0.09 & 0.38 & 0.46 & 15 & 21 & 31 \\
\hline STDDEV & $\begin{array}{l}600- \\
420 \\
0\end{array}$ & 8: SB Truck Lane & 0.03 & 0.05 & 0.29 & 0.46 & 52 & 16 & 68 \\
\hline MIN & $\begin{array}{l}600- \\
420 \\
0 \\
\end{array}$ & 1: NB 101 After Monterey & 0.21 & 0.33 & $\begin{array}{r}49.9 \\
9 \\
\end{array}$ & $\begin{array}{r}59.5 \\
7 \\
\end{array}$ & $\begin{array}{r}265 \\
3 \\
\end{array}$ & 236 & 2895 \\
\hline MIN & $\begin{array}{l}600- \\
420 \\
0\end{array}$ & 2: JCT 58 NB Off Ramp & 0.71 & 0.11 & $\begin{array}{r}55.9 \\
4 \\
\end{array}$ & $\begin{array}{r}63.1 \\
9 \\
\end{array}$ & 155 & 14 & 175 \\
\hline MIN & $\begin{array}{l}600- \\
420 \\
0\end{array}$ & 3: NB 101 End & 0.27 & -0.03 & $\begin{array}{r}52.2 \\
8\end{array}$ & $\begin{array}{r}59.5 \\
5\end{array}$ & $\begin{array}{r}212 \\
9\end{array}$ & 181 & 2336 \\
\hline MIN & $\begin{array}{l}600- \\
420 \\
0\end{array}$ & 4: SB 101 After JCT 58 & -0.04 & -0.41 & $\begin{array}{r}55.8 \\
4\end{array}$ & $\begin{array}{r}63.4 \\
2\end{array}$ & $\begin{array}{r}158 \\
2\end{array}$ & 129 & 1713 \\
\hline MIN & $\begin{array}{l}600- \\
420 \\
0\end{array}$ & 5: Monterey SB Off Ramp & 0.77 & 0.16 & $\begin{array}{r}55.4 \\
9 \\
\end{array}$ & $\begin{array}{r}63.0 \\
3 \\
\end{array}$ & 265 & 19 & 286 \\
\hline MIN & $\begin{array}{l}600- \\
420 \\
0 \\
\end{array}$ & 6: SB $101 \mathrm{End}$ & 0.32 & 0.31 & $\begin{array}{r}55.5 \\
7 \\
\end{array}$ & $\begin{array}{r}62.9 \\
5 \\
\end{array}$ & $\begin{array}{r}128 \\
3 \\
\end{array}$ & 102 & 1389 \\
\hline MIN & $\begin{array}{l}600- \\
420 \\
0\end{array}$ & 7: NB Truck Lane & -0.11 & -0.1 & $\begin{array}{r}20.8 \\
7\end{array}$ & $\begin{array}{r}45.6 \\
8\end{array}$ & $\begin{array}{r}250 \\
2\end{array}$ & 220 & 2734 \\
\hline MIN & $\begin{array}{l}600- \\
420 \\
0\end{array}$ & 8: SB Truck Lane & -0.08 & 0.09 & 30.1 & $\begin{array}{r}61.2 \\
3\end{array}$ & $\begin{array}{r}154 \\
9\end{array}$ & 128 & 1678 \\
\hline MAX & $\begin{array}{l}600- \\
420 \\
0\end{array}$ & 1: NB 101 After Monterey & 0.37 & 0.59 & $\begin{array}{r}52.2 \\
3 \\
\end{array}$ & $\begin{array}{r}60.0 \\
7 \\
\end{array}$ & $\begin{array}{r}267 \\
4 \\
\end{array}$ & 285 & 2938 \\
\hline
\end{tabular}




\begin{tabular}{|c|c|c|c|c|c|c|c|c|c|}
\hline MAX & $\begin{array}{l}600- \\
420 \\
0 \\
\end{array}$ & 2: JCT 58 NB Off Ramp & 1.02 & 0.38 & $\begin{array}{r}58.6 \\
9 \\
\end{array}$ & $\begin{array}{r}64.0 \\
2 \\
\end{array}$ & 194 & 24 & 210 \\
\hline MAX & $\begin{array}{l}600- \\
420 \\
0\end{array}$ & 3: NB 101 End & 0.62 & 0.32 & $\begin{array}{r}55.7 \\
8 \\
\end{array}$ & $\begin{array}{r}61.1 \\
6 \\
\end{array}$ & $\begin{array}{r}223 \\
7 \\
\end{array}$ & 207 & 2434 \\
\hline MAX & $\begin{array}{l}600- \\
420 \\
0\end{array}$ & 4: SB 101 After JCT 58 & 0.04 & -0.31 & $\begin{array}{r}56.6 \\
9\end{array}$ & $\begin{array}{r}63.9 \\
5\end{array}$ & $\begin{array}{r}170 \\
3\end{array}$ & 162 & 1864 \\
\hline MAX & $\begin{array}{l}600- \\
420 \\
0\end{array}$ & 5: Monterey SB Off Ramp & 0.91 & 0.44 & $\begin{array}{r}57.5 \\
2 \\
\end{array}$ & $\begin{array}{r}63.8 \\
8 \\
\end{array}$ & 320 & 28 & 343 \\
\hline MAX & $\begin{array}{l}600- \\
420 \\
0\end{array}$ & 6: SB 101 End & 0.42 & 0.43 & $\begin{array}{r}56.4 \\
2 \\
\end{array}$ & $\begin{array}{r}63.3 \\
2 \\
\end{array}$ & $\begin{array}{r}138 \\
1 \\
\end{array}$ & 137 & 1518 \\
\hline MAX & $\begin{array}{l}600- \\
420 \\
0\end{array}$ & 7: NB Truck Lane & 0.04 & 0.14 & $\begin{array}{r}21.8 \\
7\end{array}$ & $\begin{array}{r}46.8 \\
8\end{array}$ & $\begin{array}{r}254 \\
1\end{array}$ & 275 & 2810 \\
\hline MAX & $\begin{array}{l}600- \\
420 \\
0\end{array}$ & 8: SB Truck Lane & -0.01 & 0.22 & $\begin{array}{r}30.8 \\
5\end{array}$ & $\begin{array}{r}62.2 \\
3\end{array}$ & $\begin{array}{r}167 \\
9\end{array}$ & 166 & 1845 \\
\hline
\end{tabular}

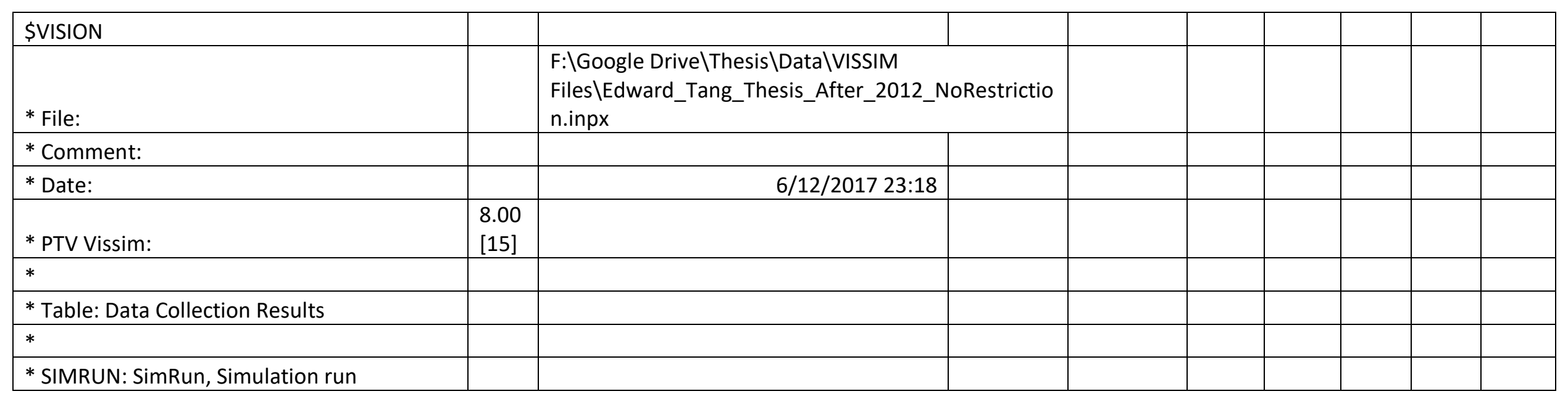


* TIMEINT: Timelnt, Time interval

* DATACOLLECTIONMEASUREMENT:

DataCollectionMeasurement, Data collection

measurement

* ACCELERATION(10): Acceleration(10), Acceleration (10) (Acceleration of all vehicles of the

the data collection measurement in the interval) [ft/s2]

* ACCELERATION(20): Acceleration(20), Acceleration (20) (Acceleration of all vehicles of the

the data collection measurement in the interval) [ft/s2]

* SPEED(10): Speed(10), Speed (10) (Speed of all vehicles of the the data collection

measurement in the interval) [mph]

* SPEED(20): Speed(20), Speed (20) (Speed of all vehicles of the the data collection

measurement in the interval) [mph]

* VEHS(10): Vehs(10), Vehicles (10) (Count of vehicles of the the data collection measurement

in the interval)

* VEHS(20): Vehs(20), Vehicles (20) (Count of vehicles of the the data collection measurement in the interval)

* VEHS(ALL): Vehs(All), Vehicles (All) (Count of vehicles of the the data collection measurement in the interval)

\begin{tabular}{|c|c|c|c|c|c|c|c|c|c|}
\hline \multicolumn{10}{|l|}{ in the interval) } \\
\hline \multicolumn{10}{|l|}{ * } \\
\hline * SimRun & $\begin{array}{l}\text { Tim } \\
\text { elnt }\end{array}$ & DataCollectionMeasurement & $\begin{array}{l}\text { Accelerati } \\
\text { on(10) }\end{array}$ & $\begin{array}{l}\text { Accelerati } \\
\text { on }(20) \\
\end{array}$ & $\begin{array}{l}\text { Spee } \\
d(10)\end{array}$ & $\begin{array}{l}\text { Spee } \\
\mathrm{d}(20)\end{array}$ & $\begin{array}{l}\text { Vehs } \\
(10)\end{array}$ & $\begin{array}{l}\text { Vehs } \\
(20)\end{array}$ & $\begin{array}{l}\text { Vehs } \\
\text { (All) }\end{array}$ \\
\hline \multicolumn{10}{|l|}{$*$} \\
\hline $\begin{array}{l}\text { \$DATACOLLECTIONMEASUREMENTEVALUAT } \\
\text { ION:SIMRUN }\end{array}$ & $\begin{array}{l}\text { TIM } \\
\text { EINT }\end{array}$ & DATACOLLECTIONMEASUREMENT & $\begin{array}{l}\text { ACCELER } \\
\text { ATION(10 } \\
\text { ) }\end{array}$ & $\begin{array}{l}\text { ACCELER } \\
\text { ATION }(20 \\
\text { ) }\end{array}$ & $\begin{array}{l}\text { SPEE } \\
\mathrm{D}(10)\end{array}$ & $\begin{array}{l}\text { SPEE } \\
\mathrm{D}(20)\end{array}$ & $\begin{array}{l}\text { VEH } \\
\text { S(10 } \\
)\end{array}$ & $\begin{array}{l}\text { VEH } \\
S(20 \\
)\end{array}$ & $\begin{array}{l}\text { VEHS } \\
\text { (ALL) }\end{array}$ \\
\hline 1 & $\begin{array}{l}600- \\
420 \\
0\end{array}$ & 1: NB 101 After Monterey & 0.27 & 0.43 & 61.5 & $\begin{array}{r}53.2 \\
6\end{array}$ & $\begin{array}{r}227 \\
1\end{array}$ & 223 & 2494 \\
\hline 1 & $\begin{array}{l}600- \\
420 \\
0\end{array}$ & 2: JCT 58 NB Off Ramp & 0.7 & 0.29 & $\begin{array}{r}63.6 \\
8\end{array}$ & $\begin{array}{r}56.8 \\
9\end{array}$ & 158 & 12 & 170 \\
\hline 1 & $\begin{array}{l}600- \\
420 \\
0\end{array}$ & 3: NB 101 End & 0.42 & 0.12 & $\begin{array}{r}60.7 \\
5\end{array}$ & $\begin{array}{r}54.8 \\
8\end{array}$ & $\begin{array}{r}209 \\
3\end{array}$ & 194 & 2287 \\
\hline
\end{tabular}




\begin{tabular}{|c|c|c|c|c|c|c|c|c|c|}
\hline 1 & $\begin{array}{l}600- \\
420 \\
0\end{array}$ & 4: SB 101 After JCT 58 & -0.03 & -0.36 & $\begin{array}{r}63.1 \\
4\end{array}$ & 55.6 & $\begin{array}{r}197 \\
2\end{array}$ & 200 & 2172 \\
\hline 1 & $\begin{array}{l}600- \\
420 \\
0\end{array}$ & 5: Monterey SB Off Ramp & 0.73 & 0.21 & $\begin{array}{r}63.9 \\
1\end{array}$ & $\begin{array}{r}57.3 \\
2\end{array}$ & 312 & 25 & 337 \\
\hline 1 & \begin{tabular}{|l|}
$600-$ \\
420 \\
0
\end{tabular} & 6: SB 101 End & 0.53 & 0.28 & $\begin{array}{r}62.2 \\
4\end{array}$ & 56.3 & $\begin{array}{r}167 \\
8\end{array}$ & 173 & 1851 \\
\hline 1 & \begin{tabular}{|l|}
$600-$ \\
420 \\
0 \\
\end{tabular} & 7: NB Truck Lane & 0 & 0.01 & $\begin{array}{r}61.1 \\
5\end{array}$ & $\begin{array}{r}20.8 \\
7\end{array}$ & $\begin{array}{r}229 \\
7\end{array}$ & 218 & 2515 \\
\hline 1 & \begin{tabular}{|l}
$600-$ \\
420 \\
0
\end{tabular} & 8: SB Truck Lane & -0.02 & -0.11 & $\begin{array}{r}63.0 \\
8\end{array}$ & $\begin{array}{r}30.2 \\
6\end{array}$ & $\begin{array}{r}197 \\
8\end{array}$ & 207 & 2185 \\
\hline 2 & $\begin{array}{l}600- \\
420 \\
0\end{array}$ & 1: NB 101 After Monterey & 0.32 & 0.47 & $\begin{array}{r}60.6 \\
4\end{array}$ & $\begin{array}{r}51.3 \\
7\end{array}$ & $\begin{array}{r}229 \\
9\end{array}$ & 233 & 2532 \\
\hline 2 & $\begin{array}{l}600- \\
420 \\
0 \\
\end{array}$ & 2: JCT 58 NB Off Ramp & 0.82 & 0.41 & 63.4 & $\begin{array}{r}57.5 \\
9 \\
\end{array}$ & 149 & 28 & 177 \\
\hline 2 & $\begin{array}{l}600- \\
420 \\
0\end{array}$ & 3: NB 101 End & 0.38 & 0.22 & $\begin{array}{r}60.2 \\
8\end{array}$ & $\begin{array}{r}54.9 \\
9\end{array}$ & $\begin{array}{r}215 \\
3\end{array}$ & 214 & 2367 \\
\hline 2 & $\begin{array}{l}600- \\
420 \\
0\end{array}$ & 4: SB 101 After JCT 58 & 0.03 & -0.42 & $\begin{array}{r}63.3 \\
1\end{array}$ & $\begin{array}{r}56.0 \\
3\end{array}$ & $\begin{array}{r}185 \\
5\end{array}$ & 185 & 2040 \\
\hline 2 & $\begin{array}{l}600- \\
420 \\
0\end{array}$ & 5: Monterey SB Off Ramp & 0.87 & 0.18 & $\begin{array}{r}63.6 \\
8\end{array}$ & $\begin{array}{r}56.7 \\
6\end{array}$ & 284 & 21 & 305 \\
\hline 2 & $\begin{array}{l}600- \\
420 \\
0 \\
\end{array}$ & 6: SB 101 End & 0.42 & 0.25 & $\begin{array}{r}62.5 \\
2 \\
\end{array}$ & 55.4 & $\begin{array}{r}159 \\
1 \\
\end{array}$ & 149 & 1740 \\
\hline 2 & $\begin{array}{l}600- \\
420 \\
0\end{array}$ & 7: NB Truck Lane & 0.04 & 0.06 & $\begin{array}{r}60.6 \\
2\end{array}$ & $\begin{array}{r}21.0 \\
8\end{array}$ & $\begin{array}{r}228 \\
4\end{array}$ & 240 & 2524 \\
\hline
\end{tabular}




\begin{tabular}{|c|c|c|c|c|c|c|c|c|c|}
\hline 2 & $\begin{array}{l}600- \\
420 \\
0\end{array}$ & 8: SB Truck Lane & 0.01 & -0.06 & $\begin{array}{r}63.2 \\
7 \\
\end{array}$ & $\begin{array}{r}30.3 \\
8 \\
\end{array}$ & $\begin{array}{r}187 \\
5 \\
\end{array}$ & 182 & 2057 \\
\hline 3 & $\begin{array}{l}600- \\
420 \\
0\end{array}$ & 1: NB 101 After Monterey & 0.33 & 0.44 & $\begin{array}{r}61.2 \\
8\end{array}$ & $\begin{array}{r}51.7 \\
7\end{array}$ & $\begin{array}{r}226 \\
8\end{array}$ & 243 & 2511 \\
\hline 3 & $\begin{array}{l}600- \\
420 \\
0\end{array}$ & 2: JCT 58 NB Off Ramp & 0.89 & 0.5 & 62.9 & $\begin{array}{r}56.8 \\
6\end{array}$ & 165 & 15 & 180 \\
\hline 3 & \begin{tabular}{|l|}
$600-$ \\
420 \\
0 \\
\end{tabular} & 3: NB 101 End & 0.62 & 0.31 & $\begin{array}{r}59.3 \\
9 \\
\end{array}$ & $\begin{array}{r}54.1 \\
2\end{array}$ & $\begin{array}{r}212 \\
3 \\
\end{array}$ & 221 & 2344 \\
\hline 3 & $\begin{array}{l}600- \\
420 \\
0\end{array}$ & 4: SB 101 After JCT 58 & 0.01 & -0.31 & $\begin{array}{r}62.9 \\
8\end{array}$ & $\begin{array}{r}54.6 \\
8\end{array}$ & $\begin{array}{r}194 \\
1\end{array}$ & 201 & 2142 \\
\hline 3 & $\begin{array}{l}600- \\
420 \\
0\end{array}$ & 5: Monterey SB Off Ramp & 0.83 & 0.25 & $\begin{array}{r}63.4 \\
5\end{array}$ & $\begin{array}{r}57.3 \\
3\end{array}$ & 314 & 29 & 343 \\
\hline 3 & $\begin{array}{l}600- \\
420 \\
0 \\
\end{array}$ & 6: SB 101 End & 0.49 & 0.29 & $\begin{array}{r}62.5 \\
7 \\
\end{array}$ & $\begin{array}{r}55.9 \\
5 \\
\end{array}$ & $\begin{array}{r}166 \\
6 \\
\end{array}$ & 149 & 1815 \\
\hline 3 & $\begin{array}{l}600- \\
420 \\
0\end{array}$ & 7: NB Truck Lane & 0.03 & -0.03 & $\begin{array}{r}60.5 \\
9\end{array}$ & $\begin{array}{r}21.4 \\
7\end{array}$ & $\begin{array}{r}231 \\
7\end{array}$ & 249 & 2566 \\
\hline 3 & $\begin{array}{l}600- \\
420 \\
0\end{array}$ & 8: SB Truck Lane & 0.06 & 0 & $\begin{array}{r}63.1 \\
6\end{array}$ & $\begin{array}{r}30.3 \\
8\end{array}$ & $\begin{array}{r}197 \\
7\end{array}$ & 199 & 2176 \\
\hline 4 & $\begin{array}{l}600- \\
420 \\
0\end{array}$ & 1: NB 101 After Monterey & 0.26 & 0.41 & $\begin{array}{r}61.1 \\
9\end{array}$ & $\begin{array}{r}52.5 \\
4\end{array}$ & $\begin{array}{r}228 \\
6\end{array}$ & 203 & 2489 \\
\hline 4 & $\begin{array}{l}600- \\
420 \\
0 \\
\end{array}$ & 2: JCT 58 NB Off Ramp & 0.85 & 0.19 & $\begin{array}{r}63.6 \\
4\end{array}$ & $\begin{array}{r}57.5 \\
5 \\
\end{array}$ & 178 & 18 & 196 \\
\hline 4 & $\begin{array}{l}600- \\
420 \\
0\end{array}$ & 3: NB 101 End & 0.35 & 0.12 & 60.6 & $\begin{array}{r}56.2 \\
4\end{array}$ & $\begin{array}{r}212 \\
6\end{array}$ & 194 & 2320 \\
\hline
\end{tabular}




\begin{tabular}{|c|c|c|c|c|c|c|c|c|c|}
\hline 4 & \begin{tabular}{|l|l}
$600-$ \\
420 \\
0
\end{tabular} & 4: SB 101 After JCT 58 & 0.01 & -0.38 & $\begin{array}{r}63.4 \\
2 \\
\end{array}$ & $\begin{array}{r}56.0 \\
1 \\
\end{array}$ & $\begin{array}{r}187 \\
5 \\
\end{array}$ & 170 & 2045 \\
\hline 4 & \begin{tabular}{|l}
$600-$ \\
420 \\
0
\end{tabular} & 5: Monterey SB Off Ramp & 0.85 & 0.27 & $\begin{array}{r}63.5 \\
2\end{array}$ & $\begin{array}{r}56.2 \\
3 \\
\end{array}$ & 324 & 19 & 343 \\
\hline 4 & \begin{tabular}{|l}
$600-$ \\
420 \\
0
\end{tabular} & 6: SB 101 End & 0.42 & 0.4 & $\begin{array}{r}62.7 \\
8 \\
\end{array}$ & $\begin{array}{r}55.6 \\
7 \\
\end{array}$ & $\begin{array}{r}159 \\
9 \\
\end{array}$ & 139 & 1738 \\
\hline 4 & \begin{tabular}{|l}
$600-$ \\
420 \\
0
\end{tabular} & 7: NB Truck Lane & -0.04 & 0.02 & $\begin{array}{r}61.0 \\
9 \\
\end{array}$ & $\begin{array}{r}21.4 \\
6 \\
\end{array}$ & $\begin{array}{r}233 \\
3 \\
\end{array}$ & 212 & 2545 \\
\hline 4 & \begin{tabular}{|l}
$600-$ \\
420 \\
0
\end{tabular} & 8: SB Truck Lane & 0.01 & -0.08 & $\begin{array}{r}63.6 \\
1\end{array}$ & $\begin{array}{r}29.9 \\
1 \\
\end{array}$ & $\begin{array}{r}188 \\
9 \\
\end{array}$ & 177 & 2066 \\
\hline 5 & \begin{tabular}{|l}
$600-$ \\
420 \\
0
\end{tabular} & 1: NB 101 After Monterey & 0.32 & 0.56 & 61 & $\begin{array}{r}51.3 \\
9\end{array}$ & $\begin{array}{r}226 \\
1\end{array}$ & 214 & 2475 \\
\hline 5 & \begin{tabular}{|l}
$600-$ \\
420 \\
0
\end{tabular} & 2: JCT 58 NB Off Ramp & 0.97 & 0.39 & $\begin{array}{r}62.8 \\
2 \\
\end{array}$ & $\begin{array}{r}56.6 \\
8 \\
\end{array}$ & 170 & 17 & 187 \\
\hline 5 & \begin{tabular}{|l}
$600-$ \\
420 \\
0 \\
\end{tabular} & 3: NB 101 End & 0.56 & 0.28 & 59.9 & $\begin{array}{r}53.3 \\
8\end{array}$ & $\begin{array}{r}214 \\
6 \\
\end{array}$ & 192 & 2338 \\
\hline 5 & \begin{tabular}{|l|}
$600-$ \\
420 \\
0 \\
\end{tabular} & 4: SB 101 After JCT 58 & -0.05 & -0.42 & $\begin{array}{r}63.1 \\
3 \\
\end{array}$ & $\begin{array}{r}55.7 \\
5 \\
\end{array}$ & $\begin{array}{r}190 \\
4 \\
\end{array}$ & 187 & 2091 \\
\hline 5 & \begin{tabular}{|l|}
$600-$ \\
420 \\
0
\end{tabular} & 5: Monterey SB Off Ramp & 0.85 & 0.15 & $\begin{array}{r}63.9 \\
1\end{array}$ & $\begin{array}{r}56.1 \\
7\end{array}$ & 323 & 24 & 347 \\
\hline 5 & $\begin{array}{l}600- \\
420 \\
0 \\
\end{array}$ & 6: SB 101 End & 0.58 & 0.36 & $\begin{array}{r}62.0 \\
8\end{array}$ & $\begin{array}{r}55.6 \\
6 \\
\end{array}$ & $\begin{array}{r}159 \\
0 \\
\end{array}$ & 159 & 1749 \\
\hline 5 & $\begin{array}{l}600- \\
420 \\
0 \\
\end{array}$ & 7: NB Truck Lane & 0 & -0.09 & $\begin{array}{r}61.2 \\
9 \\
\end{array}$ & $\begin{array}{r}21.6 \\
4 \\
\end{array}$ & $\begin{array}{r}228 \\
9 \\
\end{array}$ & 211 & 2500 \\
\hline
\end{tabular}




\begin{tabular}{|c|c|c|c|c|c|c|c|c|c|c|}
\hline & 5 & $\begin{array}{l}600- \\
420 \\
0 \\
\end{array}$ & 8: SB Truck Lane & -0.02 & -0.02 & $\begin{array}{r}63.2 \\
4 \\
\end{array}$ & $\begin{array}{r}30.8 \\
5 \\
\end{array}$ & $\begin{array}{r}192 \\
2 \\
\end{array}$ & 183 & 2105 \\
\hline AVG & & $\begin{array}{l}600- \\
420 \\
0\end{array}$ & 1: NB 101 After Monterey & 0.3 & 0.46 & $\begin{array}{r}61.1 \\
2\end{array}$ & $\begin{array}{r}52.0 \\
6\end{array}$ & $\begin{array}{r}227 \\
7\end{array}$ & 223 & 2500 \\
\hline AVG & & $\begin{array}{l}600- \\
420 \\
0\end{array}$ & 2: JCT 58 NB Off Ramp & 0.85 & 0.36 & $\begin{array}{r}63.2 \\
9 \\
\end{array}$ & $\begin{array}{r}57.1 \\
1 \\
\end{array}$ & 164 & 18 & 182 \\
\hline AVG & & $\begin{array}{l}600- \\
420 \\
0 \\
\end{array}$ & 3: NB 101 End & 0.47 & 0.21 & $\begin{array}{r}60.1 \\
8 \\
\end{array}$ & $\begin{array}{r}54.7 \\
2 \\
\end{array}$ & $\begin{array}{r}212 \\
8 \\
\end{array}$ & 203 & 2331 \\
\hline AVG & & $\begin{array}{l}600- \\
420 \\
0\end{array}$ & 4: SB 101 After JCT 58 & -0.01 & -0.38 & 63.2 & $\begin{array}{r}55.6 \\
1\end{array}$ & $\begin{array}{r}190 \\
9\end{array}$ & 189 & 2098 \\
\hline AVG & & $\begin{array}{l}600- \\
420 \\
0\end{array}$ & 5: Monterey SB Off Ramp & 0.83 & 0.21 & $\begin{array}{r}63.6 \\
9\end{array}$ & $\begin{array}{r}56.7 \\
6\end{array}$ & 311 & 24 & 335 \\
\hline AVG & & $\begin{array}{l}600- \\
420 \\
0\end{array}$ & 6: SB 101 End & 0.49 & 0.32 & $\begin{array}{r}62.4 \\
4 \\
\end{array}$ & 55.8 & $\begin{array}{r}162 \\
5 \\
\end{array}$ & 154 & 1779 \\
\hline AVG & & $\begin{array}{l}600- \\
420 \\
0\end{array}$ & 7: NB Truck Lane & 0.01 & 0 & $\begin{array}{r}60.9 \\
5 \\
\end{array}$ & 21.3 & $\begin{array}{r}230 \\
4 \\
\end{array}$ & 226 & 2530 \\
\hline AVG & & $\begin{array}{l}600- \\
420 \\
0 \\
\end{array}$ & 8: SB Truck Lane & 0.01 & -0.05 & $\begin{array}{r}63.2 \\
7 \\
\end{array}$ & $\begin{array}{r}30.3 \\
5 \\
\end{array}$ & $\begin{array}{r}192 \\
8 \\
\end{array}$ & 190 & 2118 \\
\hline STDDEV & & $\begin{array}{l}600- \\
420 \\
0\end{array}$ & 1: NB 101 After Monterey & 0.03 & 0.06 & 0.33 & 0.82 & 15 & 16 & 22 \\
\hline STDDEV & & $\begin{array}{l}600- \\
420 \\
0\end{array}$ & 2: JCT 58 NB Off Ramp & 0.1 & 0.12 & 0.41 & 0.43 & 11 & 6 & 10 \\
\hline STDDEV & & $\begin{array}{l}600- \\
420 \\
0 \\
\end{array}$ & 3: NB 101 End & 0.12 & 0.09 & 0.55 & 1.07 & 23 & 13 & 30 \\
\hline
\end{tabular}




\begin{tabular}{|c|c|c|c|c|c|c|c|c|c|}
\hline STDDEV & $\begin{array}{l}600- \\
420 \\
0\end{array}$ & 4: SB 101 After JCT 58 & 0.03 & 0.05 & 0.17 & 0.55 & 48 & 13 & 58 \\
\hline STDDEV & $\begin{array}{l}600- \\
420 \\
0\end{array}$ & 5: Monterey SB Off Ramp & 0.06 & 0.05 & 0.21 & 0.56 & 16 & 4 & 17 \\
\hline STDDEV & $\begin{array}{l}\text { 600- } \\
420 \\
0\end{array}$ & 6: SB 101 End & 0.07 & 0.06 & 0.28 & 0.34 & 43 & 13 & 51 \\
\hline STDDEV & $\begin{array}{l}\text { 600- } \\
420 \\
0\end{array}$ & 7: NB Truck Lane & 0.03 & 0.06 & 0.32 & 0.32 & 21 & 17 & 26 \\
\hline STDDEV & $\begin{array}{l}600- \\
420 \\
0\end{array}$ & 8: SB Truck Lane & 0.03 & 0.05 & 0.2 & 0.34 & 48 & 13 & 60 \\
\hline MIN & $\begin{array}{l}600- \\
420 \\
0\end{array}$ & 1: NB 101 After Monterey & 0.26 & 0.41 & $\begin{array}{r}60.6 \\
4\end{array}$ & $\begin{array}{r}51.3 \\
7\end{array}$ & $\begin{array}{r}226 \\
1\end{array}$ & 203 & 2475 \\
\hline MIN & $\begin{array}{l}600- \\
420 \\
0\end{array}$ & 2: JCT 58 NB Off Ramp & 0.7 & 0.19 & $\begin{array}{r}62.8 \\
2\end{array}$ & $\begin{array}{r}56.6 \\
8\end{array}$ & 149 & 12 & 170 \\
\hline MIN & $\begin{array}{l}600- \\
420 \\
0\end{array}$ & 3: NB 101 End & 0.35 & 0.12 & $\begin{array}{r}59.3 \\
9\end{array}$ & $\begin{array}{r}53.3 \\
8\end{array}$ & $\begin{array}{r}209 \\
3\end{array}$ & 192 & 2287 \\
\hline MIN & $\begin{array}{l}600- \\
420 \\
0\end{array}$ & 4: SB 101 After JCT 58 & -0.05 & -0.42 & $\begin{array}{r}62.9 \\
8\end{array}$ & $\begin{array}{r}54.6 \\
8\end{array}$ & $\begin{array}{r}185 \\
5\end{array}$ & 170 & 2040 \\
\hline MIN & $\begin{array}{l}600- \\
420 \\
0\end{array}$ & 5: Monterey SB Off Ramp & 0.73 & 0.15 & $\begin{array}{r}63.4 \\
5\end{array}$ & $\begin{array}{r}56.1 \\
7\end{array}$ & 284 & 19 & 305 \\
\hline MIN & $\begin{array}{l}600- \\
420 \\
0\end{array}$ & 6: SB 101 End & 0.42 & 0.25 & $\begin{array}{r}62.0 \\
8\end{array}$ & 55.4 & $\begin{array}{r}159 \\
0\end{array}$ & 139 & 1738 \\
\hline MIN & $\begin{array}{l}600- \\
420 \\
0\end{array}$ & 7: NB Truck Lane & -0.04 & -0.09 & $\begin{array}{r}60.5 \\
9\end{array}$ & $\begin{array}{r}20.8 \\
7\end{array}$ & $\begin{array}{r}228 \\
4\end{array}$ & 211 & 2500 \\
\hline
\end{tabular}




\begin{tabular}{|c|c|c|c|c|c|c|c|c|c|}
\hline MIN & $\begin{array}{l}600- \\
420 \\
0 \\
\end{array}$ & 8: SB Truck Lane & -0.02 & -0.11 & $\begin{array}{r}63.0 \\
8 \\
\end{array}$ & $\begin{array}{r}29.9 \\
1 \\
\end{array}$ & $\begin{array}{r}187 \\
5 \\
\end{array}$ & 177 & 2057 \\
\hline MAX & $\begin{array}{l}600- \\
420 \\
0\end{array}$ & 1: NB 101 After Monterey & 0.33 & 0.56 & 61.5 & $\begin{array}{r}53.2 \\
6\end{array}$ & $\begin{array}{r}229 \\
9\end{array}$ & 243 & 2532 \\
\hline MAX & $\begin{array}{l}600- \\
420 \\
0\end{array}$ & 2: JCT 58 NB Off Ramp & 0.97 & 0.5 & $\begin{array}{r}63.6 \\
8 \\
\end{array}$ & $\begin{array}{r}57.5 \\
9 \\
\end{array}$ & 178 & 28 & 196 \\
\hline MAX & $\begin{array}{l}600- \\
420 \\
0 \\
\end{array}$ & 3: NB 101 End & 0.62 & 0.31 & $\begin{array}{r}60.7 \\
5 \\
\end{array}$ & $\begin{array}{r}56.2 \\
4 \\
\end{array}$ & $\begin{array}{r}215 \\
3 \\
\end{array}$ & 221 & 2367 \\
\hline MAX & $\begin{array}{l}600- \\
420 \\
0\end{array}$ & 4: SB 101 After JCT 58 & 0.03 & -0.31 & $\begin{array}{r}63.4 \\
2\end{array}$ & $\begin{array}{r}56.0 \\
3\end{array}$ & $\begin{array}{r}197 \\
2\end{array}$ & 201 & 2172 \\
\hline MAX & $\begin{array}{l}600- \\
420 \\
0\end{array}$ & 5: Monterey SB Off Ramp & 0.87 & 0.27 & $\begin{array}{r}63.9 \\
1 \\
\end{array}$ & $\begin{array}{r}57.3 \\
3 \\
\end{array}$ & 324 & 29 & 347 \\
\hline MAX & $\begin{array}{l}600- \\
420 \\
0\end{array}$ & 6: SB 101 End & 0.58 & 0.4 & $\begin{array}{r}62.7 \\
8 \\
\end{array}$ & 56.3 & $\begin{array}{r}167 \\
8 \\
\end{array}$ & 173 & 1851 \\
\hline MAX & $\begin{array}{l}600- \\
420 \\
0\end{array}$ & 7: NB Truck Lane & 0.04 & 0.06 & $\begin{array}{r}61.2 \\
9 \\
\end{array}$ & $\begin{array}{r}21.6 \\
4 \\
\end{array}$ & $\begin{array}{r}233 \\
3 \\
\end{array}$ & 249 & 2566 \\
\hline MAX & $\begin{array}{l}\text { 600- } \\
420 \\
0 \\
\end{array}$ & 8: SB Truck Lane & 0.06 & 0 & $\begin{array}{r}63.6 \\
1 \\
\end{array}$ & $\begin{array}{r}30.8 \\
5 \\
\end{array}$ & $\begin{array}{r}197 \\
8 \\
\end{array}$ & 207 & 2185 \\
\hline
\end{tabular}

